Santa Clara Law

Santa Clara Law Digital Commons

Faculty Publications

Faculty Scholarship

2002

\title{
The Form and Substance of Environmental Justice: The Challenge of Title VI of the Civil Rights Act of 1964 for Environmental Regulation
}

Tseming Yang

Santa Clara University School of Law, tyang@scu.edu

Follow this and additional works at: http://digitalcommons.law.scu.edu/facpubs

Part of the Law Commons

\section{Automated Citation}

Tseming Yang, The Form and Substance of Environmental Justice: The Challenge of Title VI of the Civil Rights Act of 1964 for Environmental Regulation, 29 B.C. EnvtL. Aff. L. Rev. 143 (2002),

Available at: http://digitalcommons.law.scu.edu/facpubs/716

This Article is brought to you for free and open access by the Faculty Scholarship at Santa Clara Law Digital Commons. It has been accepted for inclusion in Faculty Publications by an authorized administrator of Santa Clara Law Digital Commons. For more information, please contact sculawlibrarian@gmail.com. 


\title{
THE FORM AND SUBSTANCE OF ENVIRONMENTAL JUSTICE: THE CHALLENGE OF TITLE VI OF THE CIVIL RIGHTS ACT OF 1964 FOR ENVIRONMENTAL REGULATION
}

\author{
TsEMING YANG*
}

\begin{abstract}
EPA's Title VI disparate impact regulations have become a key component of its efforts to address environmental justice issues. However, EPA's proposed implementation of these regulations through its Draft Title VI Guidance raises serious difficulties. Its attempt to combine civil rights and environmental law doctrines in a whole-sale fashion exposes significant tensions in the regulatory premises between these areas of law. The tensions are evident in how the Guidance approaches issues of minority protections, incommensurable values, and the limits of regulatory intervention. However, there are also important parallels that substantive understandings of discrimination and environmental degradation share. In particular, the role of rationally self-interested actions in shaping discriminatory and environmentally degrading behavior suggests that EPA must not only change how it regulates but also what its regulations focus on. EPA's Title VI regulation can serve an important function within such efforts to adjust both the form of its regulatory approaches as well as the substantive focus of regulatory solutions.
\end{abstract}

\section{INTRODUCTION}

In the 1950s and early 1960s, African-American and Caucasian "Freedom riders" traveled through the South to test state segregation laws, only to be met with violence. ${ }^{1}$ Peaceful protestors, including

* Associate Professor of Law, Vermont Law School. I am grateful to Sheila Foster, Eileen Gauna, Shubha Ghosh, Cynthia Ho, Gil Kujovich, Susan Kuo, and Kenneth Manaster as well as the participants of the 1999 Asian American Legal Scholarship Workshop for their valuable comments and suggestions on earlier versions of this Article. Thanks go to Elizbeth Brown, Mateo Davis, Albert Huang, Theresa Labriola, Arati Tripathi and especially Michael O'Brien for legal research, as well as Laura Gillen and Judy Hilts for manuscript assistance.

${ }^{1}$ See generally Aldon Morris, The Origins of The Civil Rights Movement 188-274 (1986). 
women and children, marched against discrimination and were attacked by police and mauled by dogs. ${ }^{2}$ And Governor George Wallace stood in the "schoolhouse door" to block African-American students from enrolling at the University of Alabama. ${ }^{3}$ When newspapers and television brought pictures of bigotry, officially condoned violence, and defiance of federal laws into our homes, the President sent federal marshals, and Congress enacted new and sweeping federal civil rights protections. 4

During those same times, smog made the air in our cities unbreathable. ${ }^{5}$ Toxic chemicals and pesticides poisoned humans, animals, and plant life. ${ }^{6}$ Our streams and lakes became so polluted that the Cuyahoga River burned. ${ }^{7}$ When environmentalists and citizens cried out to the federal government for help, Congress enacted a series of revolutionary environmental statutes, and the President created the Environmental Protection Agency (EPA). ${ }^{8}$

In the 1980s and early 1990s, a new movement began. Protestors engaged in non-violent acts of civil disobedience to prevent the dumping of toxic wastes in an African-American community in South Carolina. ${ }^{9}$ The United Church of Christ published a study documenting racial disparities in the siting of hazardous waste facilities. ${ }^{10}$ Racial minority plaintiffs brought federal law suits alleging discrimination in the siting of waste facilities and uniformly lost. ${ }^{11}$ Only with the First People of Color Environmental Summit did Congress, the President, and environmental regulators begin to pay attention to disparate pol-

2 Id.

${ }^{3} \mathrm{Id}$.

4 Id.

${ }^{5}$ See Rolf R. von Oppenfeld et al., The Common-Law Impetus for Advanced Control of Air Toxics, 29 Envtl. L. Rep. 10,003 (1999).

6 Id.

7 See James Salzman, Beyond the Smokestack: Environmental Protection in the Service Economy, 30 Envtl. L. Rep. 10,856 (2000).

- See, e.g., Philip Shabecoff, A Fierce Green Fire: The American Environmental MOVEMENT 111-20, 129-32 (1993).

9 See, e.g., Dale Russakoff, As in the '60s, Protesters Rally; But This Time The Foe Is PCB, Wash. Post, Oct. 11, 1982, at Al.

10 Commission for Racial Justice (United Church of Christ), Toxic Wastes and Race in the United States: A National Report on the Racial and Socio-Economic Characteristics of Communities with Hazardous Waste Sites (1987) [hereinafter Commission for Racial Justice, Toxic Wastes and Race in the United States].

11 See, e.g., R.I.S.E., Inc. v. Kay, 768 F. Supp. 1144, 1149-50 (E.D. Va. 1991); East Bibb Twiggs Neighborhood Assoc. v. Macon-Bibb County Planning \& Zoning Comm., 706 F. Supp. 880, 844-87 (M.D. Ga. 1989); Bean v. Southwestern Waste Mgmt. Corp., 482 F. Supp 673, 677-81 (S.D. Tex. 1979), aff'd, 782 F.2d 1038 (5th Cir. 1986). 
lution and toxic burdens visited on racial minority communities and the poor and the questions of equity and fairness in environmental regulation. ${ }^{12}$

In response to this movement, however, Congress did nothing. President Clinton issued an unenforceable Executive Order on environmental justice. ${ }^{13}$ And EPA created a federal advisory committee as well as an internal office with no substantive authority but charged with coordinating the integration of environmental justice into agency policies and activities. ${ }^{14}$

As the confluence of the two great social movements of the twentieth century, the environmental justice movement's failure to have its concerns addressed as seriously as its predecessors is striking. As an explanation of why government has not provided remedies to environmental justice claims, scholars have pointed to a lack of political power of communities of color and the poor. ${ }^{15}$ Others have also argued that civil rights laws, and in particular the equal protection doctrine, have been largely unable to respond to the discrimination and distributional inequity claims of the environmental justice movement because of the significant obstacle that the doctrine's discriminatory intent requirement creates. ${ }^{16}$

The focus of the most recent efforts to overcome these difficulties has been EPA's guidance on the investigation of administrative complaints alleging disparate discriminatory impacts under its

12 See discussion infra Part I.A.

13 Exec. Order No. 12,898, §§ 1-101, 6-609, 59 Fed. Reg. 7629 (Feb. 16, 1994).

14 See United States Enivironmental Protection Agency, Notice of Establishment of the National Environmental Justice Advisory Council and Request for Suggestions of CANDidates for Membership, 58 Fed. Reg. 59,723, 59,723-801 (Nov. 10, 1993) [hereinafter EPA Notice of EsTABLISHMENT]; see also Richard J. Lazarus, "Environmental Racism! That's What It Is., " 2000 U. IL. L. REv. 255, 263-64 (2000) (noting the scarcity of visible responses from Congress, states, and courts to environmental justice claims). But see id. at 264-73 (claiming important and widespread but relatively invisible changes in enforcement policy, standards, public participation, and environmental profession in response to environmental justice claims).

${ }^{15}$ See, e.g., Richard J. Lazarus, Pursuing Environmental Justice: The Distributional Effects of Environmental Protection, 87 Nw. U. L. Rev. 787, 806-25 (1993). Such claims have been made more generally by civil rights scholars about the lesser solicitude of government toward minority protection concerns. See, e.g., Derrick BeL,, Faces AT THE BOTTOM OF The Well: The Permanence of Racism 158-94 (1992). For an explanation as to why changing times and politics have made claims for racial and social justice less popular, see Derrick Bell, Brown v. Board of Education and the Interest Convergence Dilemma, 93 HARv. L. REv. 518, 524-33 (1980) (arguing that in the 1960s, the fight against segregation served Caucasian as much as African-American interests).

${ }^{16}$ See infra note 74 and accompanying text. 
regulations implementing the Civil Rights Act of $1964 .{ }^{17}$ These regulations apply to all recipients of EPA financial assistance. ${ }^{18}$ Since the vast majority of state and local governments implementing EPA regulatory programs receive some form of federal financial assistance and since many allegations of discrimination have involved permits issued by such state and local government agencies, EPA's Title VI Guidance has held out great promise for change. ${ }^{19}$ Yet the Guidance has been severely criticized by environmental justice advocates as being seriously deficient. ${ }^{20}$

Such criticisms have become more important in light of the Supreme Court's recent decision in Alexander $v$. Sandoval, ${ }^{21}$ finding that individual plaintiffs have no private right of action to enforce EPA's disparate impact regulations directly in court. With doctrinal developments that make it more difficult for private citizens to directly enforce EPA's Title VI disparate impact regulations, those wronged will have to place more reliance on administrative remedies to vindicate their interests. ${ }^{22}$ But more significantly, EPA's Title VI Guidance is one of the few attempts to articulate substantive decision-making criteria

17 See Draft Title VI Guidance for EPA Assistance Recipients Administering Environmental Permitting Programs (Draft Recipient Guidance) and Draft Revised Guidance for Investigating Title VI Administrative Complaints Challenging Permits (Draft Revised Investigation Guidance), 65 Fed. Reg. 39,650, 39,667-39,670 (June 27, 2000) [hereinafter Draft Title VI Recipient and Revised Investigation Guidance]; see also infra notes 130-131 and accompanying text.

18 Id.

${ }^{19} \mathrm{Id}$.

20 See Letter from Luke W. Cole et al. to Carol Browner, Comments on Draft Revised Guidance for Investigating Title VI Administrative Complaints Challenging Permits (Aug. 26,2000 ) (on file with author) (containing comments by 125 environmental organizations and individuals), available at http://www.epa.gov/civilrights/docs/t6com2000_071.pdf (last visited Jan. 15, 2002) [hereinafter Letter from Luke W. Cole]. Public comments on the Draft Revised Guidance can be found at Comments Received on the Title VI Draft Guidance Documents, at http://www.epa.gov/civilrights/t6guidcom.htm (last visited Jan. 15, 2002) [hereinafter Public Comments on Draft Revised Guidance].

21121 S. Ct. 1511, 1523 (2001).

22 Sandoval does not appear to foreclose all attempts by private citizens to enforce EPA's Title VI disparate impact regulations. See id. Section 1983 suits may provide an alternative remedy that could reach many of the same violations. See 42 U.S.C. $\$ 1983$ (2000) (stating "[e]very person who, under color of any statute, ordinance, regulation, custom, or usage, of any State ... subjects, or causes to be subjected, any citizen of the United States ... to the deprivation of any rights, privileges, or immunities secured by the Constitution and laws, shall be liable to the party injured in an action at law, suit in equity, or other proper proceeding for redress ....); see also Sandoval, 121 S. Ct. at 1522 (Stevens, J., dissenting). But see S. Camden Citizens in Action v. New Jersey Dept. of Envtl. Protection, 274 F.3d 771 (3d Cir. 2001). See generally Bradford C. Mank, Using Section 1983 to Enforce Title VI's Section 602 Regulations, 49 U. KAN. L. REv. 321 (2001). 
for government officials (and industry) interested in acting responsibly with regard to the concerns of the environmental justice movement. ${ }^{23}$ To the extent that such substantive criteria fail to advance or protect the very interests of racial minorities, as well as communities raising environmental justice issues more generally, such failings must be taken very seriously.

Many of the difficulties that regulators have encountered in addressing environmental justice issues can be traced to the vastly different regulatory paradigms that environmental regulators and environmental justice activists bring to their understanding of the role of government intervention in solving environmental justice problems. ${ }^{24}$ These difficulties have not been resolved in EPA's Title VI Guidance and raise questions about the effectiveness of the Guidance in solving environmental justice problems.

Yet, in formulating its Title VI Guidance, EPA has also sought to rely on approaches that other agencies have used in their implementation and enforcement of Title VI regulations. ${ }^{25}$ As a result, the application of Title VI to environmental issues also raises larger issues with regard to the ability of traditional civil rights mechanisms to solve race and equity problems in environmental regulation. These difficulties suggest that EPA needs to examine more closely the substance of the problems raised by activists. It needs to tailor its interventions specifically to the issues raised rather than routinely adapting approaches used elsewhere. To address environmental justice issues effectively, EPA must reshape its regulatory approaches, including its approach to Title VI, in both form and substance. ${ }^{26}$

Part I of this Article provides background on the environmental justice movement and the problems that it has encountered in seeking remedies under the civil rights and environmental laws. ${ }^{27}$ Part I also presents an overview of the Title VI Draft Revised Investigation Guidance. ${ }^{28}$

Part II details the regulatory frameworks of civil rights law and environmental law that the environmental justice movement has 39,650 .

23 See Draft Title VI Recipient and Revised Investigation Guidance supra note 17, at

24 See Tseming Yang, Melding Civil Rights and Environmentalism: Finding Environmental Justice's Place in Environmental Regulation, 26 HARV. EnvTL. L. REv. (forthcoming 2002).

25 See, e.g., infra note 233 and accompanying text.

See discussion infra Part IV.

27 See discussion infra Part I.

28 See discussion infra Part I. 
brought together. ${ }^{29}$ These frameworks are based on fundamentally different regulatory premises with regard to minority protection concerns, the role of incommensurable values in regulatory decisionmaking, and the limits of appropriate regulation. Unfortunately, in implementing its Title VI Guidance, EPA has not resolved many of the tensions that have made it difficult to address environmental justice problems in the first place.

Part III examines the respective underlying substantive social problems that environmental law and civil rights law seek to address. ${ }^{30}$ Modern understandings of race discrimination and environmental degradation view those underlying social problems as resulting in large part from rationally self-interested actions. These views underscore that discrimination and environmental degradation occur regardless of evil motivations and that an important role of civil rights and environmental law in redressing these problems is to change the incentives that prompt them in the first place. In the end, effective regulation to redress problems of environmental justice must look past the traditional conceptions of racial animus and prejudice and focus on the incentives and disincentives that lead to discriminatory actions.

Part IV suggests changes that EPA will need to make to incorporate this understanding of discrimination and environmental justice into its regulatory framework. ${ }^{31}$ Because of broad delegation to agencies of regulatory authority over discrimination in federally funded programs, Title VI provides unique opportunities in this regard. ${ }^{32}$ In particular, EPA needs to alter the form of its regulatory decisionmaking process, for instance by incorporating adjudicative processes into its Title VI process. It will also need to change the substantive focus of its regulatory efforts by addressing the incentives and biases that encourage actions with discriminatory outcomes or that perpetuate pre-existing inequities and discrimination. In this regard, its role within the National Environmental Policy Act ${ }^{33}$ can provide a useful precedent for an enhanced role within Title VI as well as its activities under other environmental statutes.

\footnotetext{
${ }^{29}$ See discussion infra Part II.

${ }^{30}$ See discussion infra Part III.

${ }^{31}$ See discussion infra Part IV.

3242 U.S.C. $\$ 2000 \mathrm{~d}(2000)$.

${ }^{33}$ Id. $\S 4331$.
} 


\section{Environmental Protection and Environmental Justice}

\section{A. Race, Equity, and the Environment}

The environmental justice movement has been one of the most important influences on environmentalism in recent years. ${ }^{34}$ Concerns about race, equity, and fairness in environmental protection, however, have long predated the recent rise of the environmental justice movement in the United States. ${ }^{35}$

In the late 1960s and early 1970s, civil rights activists and scholars commented that the federal government's newfound focus on environmental problems might draw resources and attention away from the lingering effects of a century of state sanctioned segregation and discrimination..$^{36}$ At the same time, activists and scholars were also concerned that regulatory efforts themselves would not be focused on the distributional impacts of environmental regulations on racial minorities. ${ }^{37}$ These concerns fell on deaf ears. ${ }^{38}$

In 1982, protests about the siting of a hazardous waste facility among predominately African-American and poor communities in Warren County, North Carolina, raised race and equity issues in one of their most concrete forms. ${ }^{39}$ Frequently pointed to as the visible beginnings of the environmental justice movement, the incident en-

34 See, e.g., The Law of Environmental Justice: Theories and Procedures to AdDRESS DisPROPORTIONATE Risks, at xxix-xxxi (Michael B. Gerrard ed., 1999).

${ }^{35}$ Scholars have pointed to the discrimination that African-Americans and other minorities faced with regard to the provisioning of municipal services during the times of Jim Crow and racial segregation laws as early examples of environmental injustice. See, e.g., Hawkins v. Town of Shaw, 437 F.2d 1286, 1288-91 (5th Cir. 1971). In posing the discrimination struggle as a fight for equal benefits from government works, they can be seen as the flip-side of the more recent environmental justice complaints regarding unequal treatment in the distribution of undesirable land uses. See Vicki Been, What's Fairness Got to Do With It? Environmental Justice and the Siting of Locally Undesirable Land Uses, 78 CoRNELL L. Rev. 1001, 1003 n.9 (1993); Lazarus, supra note 15, at 807, 833. In both instances, residential segregation provided an easy mechanism by which municipalities could limit not only the benefits of municipal services such as sanitary sewers, street lighting, and potable water supplies, but arguably also the shift of undesirable facilities, such as waste facilities and polluting industries, to minority neighborhoods. See id.

${ }^{36}$ See Lazarus, supra note 15 , at 788-89.

37 Id.

38 Id. at 789, 836-38 (noting that EPA made a conscious decision in the early 1970s to enforce anti-discrimination requirements of Title VI of the Civil Rights Act less than aggressively).

${ }^{39}$ See, e.g., Russakoff, supra note 9, at Al. For further accounts of the history and varied perspectives of the environmental justice movement, see Confronting Environmental RACISM: VoICES FROM THE Grassroots (Robert D. Bullard ed., 1993). 
gaged African-American and poor individuals in civil rights-style acts of civil disobedience against the establishment of a polychlorinated biphenyl (PCB) waste disposal site within the county. ${ }^{40}$ Protestors alleged racist motivations in the disposal of highly hazardous PCB wastes in a predominately African-American rural community, yet regulators refused to intervene. ${ }^{41}$ In the end, the community residents were unable to stop the establishment of the facility. ${ }^{42}$ But its graphic images of protestors lying in the roads to block trucks carrying hazardous waste and the disturbing claims of regulatory discrimination galvanized others into action. ${ }^{43}$

As a result of this incident, a number of studies, including one by the General Accounting Office (GAO) and another by the Commission for Racial Justice of the United Church of Christ, inquired into racial disparities in the correlation between hazardous waste facility siting and the racial make-up of host communities. ${ }^{44}$ The GAO study found that of four off-site hazardous waste landfills located within the eight-state jurisdiction of EPA's Region IV, three were located in predominately African-American communities ${ }^{45}$ even though they only made up twenty percent of the region's population. ${ }^{46}$ The Commission for Racial Justice study found that three of every five African and Hispanic-Americans lived in communities with uncontrolled toxic waste sites, and that race proved to be the most significant among the variables tested in association with the location of commercial hazardous waste facilities. ${ }^{47}$

A 1992 study by the National Law Journal, examining government enforcement of environmental laws at 1177 Superfund toxic waste sites concluded that "[p]enalties under hazardous waste laws at

40 See, e.g., Christopher H. Foreman, Jr., The Promise and Peril of EnvironMENTAL Justice 17-18 (1998); Russakoff, supra note 9, at A1.

41 See, e.g., Russakoff, supra note 9, at A1.

22 See, e.g., Foreman, supra note 40, at 18.

43 See, e.g., Dorceta E. Taylor, Environmentalism and the Politics of Inclusion, in ConrronTING ENVIRONMENTAL RACISM: VoICES From THE Grassroots, supra note 39, at 53, 55-56.

44 U.S. General Accounting Office, Siting of Hazardous Waste Landfills and Their Correlation with Racial and Economic Status of Surrounding Communities (1983) [hereinafter U.S. General Accounting Office, Siting of Hazardous Waste LANDFILls]; see, e.g., Charles Lee, Beyond Toxic Wastes and Race, in Confronting EnvironMENTAL RACISM: VoICES FROM THE GRASSROOTS, supra note 39, at $41,43$.

is U.S. General Accounting Office, Siting of Hazardous Waste Landfills, supra note 44 , at 1,3 .

46 See id.

47 Commission for Racial Justice, Toxic Wastes and Race in the United States, supra note 10 , at xiii-xiv. 
sites having the greatest white population were about $500 \%$ higher than penalties at sites with the greatest minority population." ${ }^{8}$ The same study also found that for "all the federal environmental laws aimed at protecting citizens from air, water and waste pollution, penalties in white communities were $46 \%$ higher than in minority communities." 49 Many other studies, focusing on other aspects of environmental regulation, resulted in similar findings. ${ }^{50}$

Yet, environmental regulators have not been the only actors connected to discrimination in environmental protection. In earlier times, in keeping with prevailing attitudes, racist attitudes among environmentalists and environmental organizations such as the Sierra Club were also quite common.51 More recently, such issues have focused on the lack of racial minorities on the staffs of such organizations. ${ }^{52}$ But there have also been complaints about the discriminatory implications of their substantive work, which is directed primarily at issues, such as wilderness preservation, that have had little relevance to minority and poor communities. ${ }^{53}$ As an extreme example, recent

48 Marianne Lavelle \& Marcia Coyle, A Special Investigation: Unequal Protection: The Racial Divide in Environmental Law, NAT'L L.J., Sept. 21, 1992, at S1.

${ }^{49} \mathrm{Id}$.

${ }^{50}$ For an overview of the studies, see, for example, Craig Anthony Arnold, Planning Milagros: Environmental Justice and Land Use Regulation, 76 Denv. U. L. REv. 1, 16-26 (1998). Of course, there has been much criticism of these studies. See, e.g., Vicki Been, Analyzing Evidence of Environmental Justice, 11 J. LAND USE \& ENVTL. L. 1, 21 (1995) (suggesting environmental racism is not a simple correlation but a complex entanglement of class, race, educational attainment, and other factors); Vicki Been \& Francis Gupta, Coming to the Nuisance Or Going to the Barrios? A Longitudinal Analysis of Environmental Justice Claims, 24 ECOLOGY L.Q. 1, 33-35 (1997); Michael Greenberg, Proving Environmental Inequity in Siting Locally Unwanted Land Uses, 4 RISK 235, 250-52 (1993); Thomas Lambert \& Christopher Boerner, Environmental Inequity: Economic Causes, Economic Solutions, 14 YALE J. ON REg. 195, 203-12 (1997) (finding "no significant difference" in percentages of minority residents in areas with or without active facilities in St. Louis, MO).

51 See, e.g., Charles Jordan \& Donald Snow, Diversification, Minorities, and the Mainstream Environmental Movement, in Voices from the Environmental Movement: Perspectives FOR A NEW ERA 71, 75-78 (Donald Snow ed., 1992) (noting that several of the Sierra Club's California chapters prohibited membership by racial minority individuals up until the 1950s).

52 See, e.g., id. at 78, 90-94, 100-01.

53 See Mark Dowie, Losing Ground: American Environmentalism at the Close of The Twentieth Century 168, 160-66 (1995); see also Victoria Slind-Flor, Amid Board Rancor, Sierra Club LDF Loses 2d Black: Staff Attorney Quits and Rekindles Dispute Over Environmental Racism, NAT'L L.J., Oct. 30, 1995, at A6 (reporting that former Sierra Club Legal Defense Fund board member equated the NAACP with a "black man's Ku Klux Klan" and described the role of an African-American woman judge as chair of the board as "interesting because in the $\mathbf{4 0}$ years $I$ have worked intensely in environmental matters, I have found total disinterest among children or adults of your race in environmental matters," and 
referenda within the Sierra Club have sought adoption of official Club positions that would support curbs on legal immigration, with the publicly asserted rationale of protecting the United States environment from the burdens of additional residents. ${ }^{54}$ The strong nativist and racist overtones of such efforts were apparent. ${ }^{55}$ While such "life-boat" attitudes ${ }^{56}$ might be explained by self-interested concern for the environment over other people, ${ }^{57}$ the ties of anti-immigration policy supporters to well-known racist groups and the primary focus on immigrants of color showed how disingenuous the environmental justifications were in deflecting claims of racial bigotry. ${ }^{58}$

Grass roots organizing and growth of the movement around such issues eventually culminated in 1991 in the First National People of Color Environmental Summit and much greater national awareness about the problems of race and equity in environmental protection. ${ }^{59}$ Since then, the movement has been successful in prompting federal responses at a number of levels. In government, the Clinton Administration issued a Presidential Executive Order directing federal agen-

noted the total disinterest of African natives, based on their hereditary cultural views, in the environment as well as the pain and suffering of animals). at Al.

${ }^{54}$ See, e.g., Frank Clifford, Immigration Vote Divides Sierra Club, L.A. Times, Mar. 16, 1998,

${ }^{55}$ See id.

56 Intended as a satire in the vein of Jonathan Swift's A Modest Proposal, Richard D. Lamm's essay, The Heresy Trial of the Reverend Richard Lamm, 15 ENvTL. L. 755 (1985), provides an excellent exposition of such attitudes.

57 Garrett Hardin, the author of the seminal article, The Tragedy of the Commons, 162 Science 1243 (1968), has been one of the most extreme proponents of deliberate selfishness in the use of limited natural resources. Thus, he advocated in the 1950s against the extension of U.S. aid to developing countries, in particular famine relief, because of his apparent belief that it would be counterproductive to solving global overpopulation. See, e.g., Shabecoff, supra note 8, at 94-96 (1993). According to Hardin:

How can we help a foreign country to escape from overpopulation? Clearly the worst thing we can do is send food .... Atomic bombs would be kinder. For a few moments the misery would be acute but it would soon come to an end for most of the people, leaving a few survivors to suffer thereafter.

Garrett Hardin, The Limits of Altruism: An Ecologist's View of Survival (1977).

In more recent times, Hardin has been unabashed in his justification of discrimination as a form of "kin altruism" in which an individual seeks to benefit only those to whom he or she might be biologically related, based on the implication that individuals of the same race are more closely related biologically than between races. GARRETT HARDIN, Living Within Limits 230 (1993). According to Hardin, "discrimination is a necessary part of every persisting altruistic behavior." Id.

s8 See, e.g., Ruth Conniff, The War on Aliens: The Right Calls the Shots, The Progressive, Oct. 1993, at 22.

${ }^{59}$ See DowiE, supra note 53, at 151-55. 
cies to consider the environmental justice implications of their decision-making..$^{60}$ Additionally, EPA established internally the Office of Environmental Justice and created the National Environmental Justice Advisory Council as an outside advisory body. ${ }^{61}$ Mainstream environmental organizations have also stepped forward by creating projects and offices to address environmental justice concerns. ${ }^{62}$ Moreover, academic attention to environmental justice issues has mushroomed. ${ }^{63}$

Of course, concerns about racism and distributional equity have naturally not been confined to domestic environmental issues alone. ${ }^{64}$ Within international environmental protection efforts, such concerns have been labeled as developing country/developed country equity issues and environmental human rights concerns. These issues have been raised in the context of environmental devastation due to destructive natural resource extraction processes ${ }^{65}$ or nuclear weapons testing, ${ }^{66}$ as well as past dispossession of land for the benefit of expatriate settlers during colonial times. ${ }^{67}$ While these issues fundamen-

${ }^{60}$ Exec. Order No. 12,898, 59 Fed. Reg. 7629 (Feb. 11, 1994).

${ }^{61}$ See EPA Notice of Establishment, supra note 14.

62 See, e.g., DowIE, supra note 53, at 147, 153.

63 See, e.g., Carita Shanklin, Pathfinder: Environmental Justice, 24 Ecology L.Q. 333 (1997); Robert W. Collin, Review of the Legal Literature on Environmental Racism, Environmental Equity, and Environmental Justice, 9 J. EnvTL. L. \& LITIG. 121 (2000).

64 See, e.g., Dana Alston \& Nicole Brown, Global Threats to People of Color, in ConfrontING ENVIRONMENTAL RACISM: VoICES From THE GRASSROOTS, supra note 39, at 179, 17994.

65 See Antony Anghie, "The Heart of My Home": Colonialism, Environmental Damage, and the Nauru Case, 34 HARv. INT'L L.J. 445, 445-48(1993) (discussing international law consequences of destruction of the environment on the island of Nauru during guano mining).

66 See, e.g., Nuclear Tests, (N.Z. v. Fr.), 1974 I.C.J. 457 (Dec. 20, 1974) (discussing New Zealand's suit in International Court of Justice protesting French atmospheric nuclear tests in the South Pacific at France's Mururoa atoll); Lori Osmundsen, Paradise Preserved? The Contritution of the SPREP Convention to the Environmental Welfare of the South Pacific, 19 Ecology L.Q. 727, 760-63, 771-73 (1992) (discussing weaknesses of nuclear testing agreements and treaties in the South Pacific).

67 See, e.g., Robin Palmer, Land and Racial Domination in Rhodesia (1977). See generally Tseming Yang, International Environmental Protection: Human Rights and the NorthSouth Divide, in Justice and Natural Resources 87, $94-98$ (Kathryn Mutz et al. eds., 2002). Many of the parallels can be traced back to the history of colonialism and the roles that developed and developing countries played within it. In such colonial relationships, the familiar racist ideology of white European racial and cultural superiority over nonwhites furnished much of the justification for the colonial system. Id. Under the mantle of the civilizing mission of the colonial powers, it was the perceived moral duty of the "civilized" European colonial powers to subjugate the non-white "savages" in order to enlighten, educate, and convert them to Christianity. See also Johnson v. M'Intosh, 21 U.S. 543, 573 (1823) (noting the justifications used by Europeans for appropriating American 
tally involve the same concerns of participation, fairness, and distribution that have been raised by environmental justice activists in the U.S., they have commanded far more attention. ${ }^{68}$

This raises a puzzling question. Given the greater significance of equity issues in international environmental treaties and other regulatory efforts, why has the domestic environmental justice movement been comparatively unsuccessful in achieving substantive solutions to its complaints? One obvious reason may be attributable to the realities of state sovereignty and global environmental politics. The moral force of equity and fairness arguments by developing countries are backed up by the leverage that sovereign nations may exercise through their ability to withhold their consent and cooperation with international efforts to address environmental problems or other actions desired by developed nations. Thus, resolution of equity and fairness issues have become top priorities for achieving effective broad-based solutions to important global environmental problems, such as climate change. No such leverage is available to domestic en-

lands: “[ $t$ ]he potentates of the old world found no difficulty in convincing themselves that they made ample compensation to the inhabitants of the new, by bestowing on them civilization and Christianity, in exchange for unlimited independence"); see generally Ruth Gordon, Saving Failed States: Sometimes a Neocolonialist Notion, 12 AM. U.J. INT'L L. \& PoL'y 903, 930-47 (1997); Robert A. Williams, Jr., The American Indian In Western Legal Thought: The Discourses of Conguest 119-232 (1990). These beliefs provided the moral excuse for colonial powers to exploit land and resources of the non-white colonies, just as it justified conquest, slavery, and discrimination against people of color within the United States. See id.

De-colonization and independence of former colonies did not necessarily end such relationships of exploitation and inequality. See, e.g., STEPHEN Schlesinger \& STEPHEN KINzer, Bitter Fruit: The Untold Story of THE American Coup in Guatemala (1982) (discussing covert U.S. intervention in Guatemala to protect plantations and lands of the Boston-based United Fruit Company (now Chiquita)); see also Osmundsen, supra note 66, at 735-38. More broadly, the consequences of colonial exploitation and inequality continue to affect global environmental problems, such as ozone depletion and global warming, where developing countries have been asked to help address what has largely been the result of past and present contributions to global environmental degradation by developed countries. David Hunter et al., International Environmental Law and Policy 56971, 631-35 (1998).

${ }^{68}$ In many international environmental problems, issues of equity have become of central importance. See, e.g., Rio Declaration on Environment and Development, June 14, 1992, 31 I.L.M. 874 (enumerating principles for global environmental partmership and emphasizing that the needs of the least developed and most environmentally vulnerable countries shall be given special priority); United Nations Framework Convention on Climate Change, May 19, 1992, 31 I.L.M. 849 (stating that parties should protect the climate system for the benefit of present and future generations on the basis of equity); see generally Joyeeta Gupta, The Climate Change Convention and Developing Countries: From Conflict To Consensus? (1997) (examining the imbalance in knowledge and negotiating power between industrialized and developing countries). 
vironmental justice activists as they cannot unilaterally exempt themselves from the applicability of federal environmental regulations.

The recurrent failure of ordinary political processes to provide adequate relief for grievances raising discrimination, distributional equity, and fairness issues, however, has been well understood by the law. Various sources of recourse exist under both statutory and constitutional law. ${ }^{69}$ The larger question that this raises is why existing domestic remedies to claims of discrimination and distributional inequities have been inadequate.

\section{B. The Obstacles to Environmental Justice}

\section{The Failure of the Existing Law for Environmental Justice}

In the past, the courts frequently were venues of last resort for environmentalists and civil rights activists alike. When political and regulatory processes failed them, courts often lent a sympathetic ear. But that has largely not been the case for environmental justice plaintiffs. ${ }^{70}$

For example, simple application of traditional civil rights tools, such as equal protection claims, have met with very limited success when raised in environmental discrimination suits. ${ }^{71}$ The primary reason for this failure has been located in the discriminatory intent requirement and the formidable obstacles it presents to succeeding in many civil rights claims. ${ }^{72}$

69 The wealth of civil rights remedies range from the Constitution's Equal Protection and Due Process Clauses to various civil rights statutes, such as the Civil Rights Act of 1964 . The field is much too broad for a quick review here. For a general overview, see THEOdore Eisenberg, Givil Rights Legislation (1996).

${ }^{70}$ A partial explanation may be an increasingly politically conservative judiciary.

71 See, e.g., R.I.S.E., Inc. v. Kay, 768 F. Supp. 1144, 1149-50 (E.D. Va. 1991) (finding that plaintiffs did not present sufficient evidence to meet standard of intentional discrimination); East Bibb Twiggs Neighborhood Ass'n v. Macon-Bibb County Planning \& Zoning Comm., 706 F. Supp. 880, 887 (M.D. Ga. 1989) (finding in favor of defendants that location of landfill was not improperly motivated by race); Bean v. Southwestern Waste Mgmt. Corp. 482 F. Supp. 673, 681 (S.D. Tex. 1979), aff'd, 782 F.2d 1038 (5th Cir. 1986) (denying motion for preliminary injunction based on statistical evidence presented; plaintiffs failed to establish substantial likelihood of success on the merits).

72 See, e.g., Luke W. Cole, Environmental Justice Litigation: Another Stone in David's Sling, 21 Fordham Urb. L.J. 523, 538-41(1994); Leslie A. Coleman, It's the Thought That Counts: The Intent Requirement in Environmental Racism Claims, 25 ST. MARY's L.J. 447 (1993) (arguing that proof of discriminatory intent should not be the sine qua non of an equal protection challenge to environmental racism); Rachel Godsil, Remedying Environmental Racism, 90 Mich. L. REv. 394, 409-11, 420-22 (1991). 
In environmental litigation, the difficulties that this requirement presents are readily apparent. A myriad of factors are important in environmental decision-making, ranging from scientific/technical considerations to economic ones. ${ }^{78}$ Because none alone is dispositive, it is easy to hide discrimination behind a host of technical information. But even more importantly, the discriminatory intent requirement is premised on the existence of a particular, identifiable bigoted actor or a bigoted act that can be blamed for the discriminatory result. ${ }^{74}$ The requirement purposefully ignores the fact that discriminatory outcomes are frequently the result of processes that cannot be traced to any specific actor or act, but are instead the result of institutions and processes that are biased against racial minorities. ${ }^{75}$ Such discriminatory biases are naturally submerged by complex regulatory processes.

Administrative agency regulations under Title VI of the Civil Rights Act, extending the prohibition of discrimination by recipients of federal assistance to discriminatory impacts, represent an important exception to the discriminatory intent requirement. ${ }^{76}$ Yet, even though the promise of such approaches is great, as discussed below, current implementation efforts by EPA raise troubling questions as to the efficacy of such administrative processes. ${ }^{77}$

Creative tailoring of traditional environmental legal claims to the needs and particular circumstances of environmental justice communities has met with somewhat greater success. ${ }^{78}$ Their overall effectiveness for the movement, however, has been less than clear. ${ }^{79}$ For

${ }^{73}$ Godsil, supra note 72, at 398-401; Collin, supra note 63, at 125-26; see generally Robert R. Kuehn, A Taxonomy of Environmental Justice, 30 Envtl. L. Rep. 10,681 (2000).

74 See, e.g., Ian Haney Lopez, Institutional Racism: Judicial Conduct and a New Theory of Racial Discrimination, 109 YALE L.J. 1717 (2000) (pointing to factors other than purposeful action as causes for discrimination). But see Alice Kaswan, Environmental Laws: Grist for the Equal Protection Mill, 70 U. CoLo. L. REv. 387, 390 (1999) (arguing that environmental laws can help provide evidence of discriminatory intent).

${ }^{75}$ See, e.g., Lopez, supra note 74 (suggesting the importance of institutional processes); Charles Lawrence, The Id, the Ego, and Equal Protection: Reckoning with Unconscious Racism, 39 Stan. L. Rev. 317, 330 (1987) (stating that racism is in large part a product of the unconscious).

${ }^{76}$ Bradford Mank, Title VI, in The Law of Environmental Justice: Theories and Procedures to AdDress Disproportionate Risks, supra note 34, at 23-24, 31.

77 See infra Part I.C.

78 See Cole, supra note 72, at 525, 529-30 (discussing a four-tier litigation strategy based on traditional environmental law claims, unusual environmental law claims, statutory civil rights claims, and constitutional civil rights claims).

${ }^{79}$ Some scholars have emphasized the effectiveness of non-legal or state law strategies. See, e.g., Luke W. Cole, The Struggle of Kettleman City: Lessons for the Movement, 5 MD. J. CoN- 
example, even though environmental citizen-suits have allowed private individuals to bring enforcement actions against polluters or against the federal government itself, they have been inadequate for environmental justice communities. ${ }^{80}$ Citizen-suit provisions do not provide for private damages and thus create no fund out of which litigation costs may be paid by poor plaintiffs. ${ }^{81}$ Attorney fees may be awarded if the suit is successful..$^{82}$ As has been pointed out by Eileen Gauna, however, both the delay in the payment of such fees, as well as the inherent litigation risk, significantly reduces the incentives that such fee-shifting provisions provide to attorneys to take on environmental justice claims. ${ }^{83}$

Provisions requiring compliance with particular decision-making processes, including public participation, have also been identified as potentially useful for environmental justice activists because they provide important opportunities for judicial intervention. ${ }^{84}$ Because such requirements are typically part of most permitting processes, they hold the promise of meeting widespread complaints that environmental decision-making processes fail to consider local community

TEMP. LEGAL Issues 67, 77-80 (1994) (arguing that legal approaches are the least favored approaches to solving environmental problems; in the alternative, political struggles are necessary). Peter L. Reich, Greening the Ghetto: A Theory of Environmental Race Discrimination, 41 U. KAN. L. REv. 271, 300 (1992) (arguing that state law offers a wider range of possibilities for dealing with environmental race discrimination than does federal law); Naikang Tsao, Ameliorating Environmental Racism: A Citizens' Guide to Combatting the Discriminatory Siting of Toxic Waste Dumps, 67 N.Y.U. L. REv. 366, 379-80 (1992) (advocating that litigants explore state statutory, common law, and constitutional litigation strategies as alternatives to federal law claims).

${ }^{80}$ See generally Eileen Gauna, Federal Environmental Citizen Provisions: Obstacles and Incentives on the Road to Environmental Justice, 22 EcOLOGY L.Q. 1, 42-45, 86-87 (1995) (arguing that enhanced access to courts may help to correct environmental inequities).

81 See id. at 43 (suggesting that lack of financial resources may defer citizen enforcers).

82 Id. at 76-78.

${ }^{83}$ See id. at 76-79. Moreover, the Supreme Court's recent decision in Buckhannon Board $\mathcal{E}$ Care Home v. West Virginia casts further doubt on the ability of environmental citizen plaintiffs to recover attorney fees. 532 U.S. 598, 860 (2001). There, the Court found that the plaintiffs did not prevail in the law suit, and thus could not qualify for attorney fees even though the suit brought about voluntary change in defendant's conduct. Id. Buckhannon does not conclusively answer whether a defendant may avoid attorney fees claims if defendant complies with plaintiffs' demands prior to adjudication of the claim. $I d$. at 86566.

84 See, e.g., Sheila Foster, Public Participation, in The Law of Environmental Justice: Theories and Procedures to AdDress Disproportionate Risks, supra note 34, at 185, 185-201, 206-09 [hereinafter Foster, Public Participation]; Sheila Foster, Race(ial) Matters: The Quest for Environmental Justice, 20 Ecology L.Q. 721, 749-52 (1993) [hereinafter Foster, Race(ial) Matters]; Alice Kaswan, Environmental Justice: Bridging the Gap Between Environmental Laws and "Justice," 47 AM. U. L. REv. 221, 251-52 (1995). 
concerns adequately. ${ }^{85}$ Increased participation of local communities should theoretically address such concerns and arguably result in a final decision that takes better account of such interests. ${ }^{86}$ The failing of such processes, however, is that they do not require specific substantive outcomes that courts can enforce. Procedural requirements, while capable of influencing the outcome, can rarely prevent substantively adverse regulatory decisions.

Finally, environmental provisions that require gathering or disclosure of information, such as the Toxic Release Inventory ${ }^{87}$ or the National Environmental Policy Act, ${ }^{88}$ have proven useful to environmentalists in responding to regulatory violations or in identifying more general problems of pollution at a facility. ${ }^{89}$ Such provisions can also be useful by providing evidence supportive of discrimination claims. ${ }^{90}$ In the end, however, merely facilitating the assembly of proof of environmental injustice cannot change the underlying substantive legal requirements necessary for making out a claim.91 Substantive standards, such as the difficult-to-prove discriminatory intent requirement of most civil rights claims, inherently disfavor environmental justice activists.

\section{The Meaning of Environmental Justice}

Apart from pointing to the inadequacy of environmental and civil rights law for the vindication of environmental justice complaints, there have also been less sympathetic views of why the movement has found it so difficult to succeed in substantively changing how regulators address environmental justice issues. These views suggest that environmental justice is about "political opportunism," jobs, or narrow disputes about discrimination in waste facility siting. ${ }^{92}$ At their base,

85 See, e.g., Foster, Public Participation, supra note 84, at 185-201, 206-09; Foster, Race(ial) Matters, supra note 84, at 749-52; Kaswan, supra note 84, at 251-52.

86 See, e.g., Foster, Public Participation, supra note 84, at 185-201, 206-09; Foster, Race(ial) Matters, supra note 84, at 749-52; Kaswan, supra note 84, at 251-52.

87 Emergency Planning and Community Right-To-Know-Act of 1986, 42 U.S.C. $\$ \$ 11,001,11,044$ (a) (2000) (requiring information be made available to the public).

${ }^{8} 42$ U.S.C. $\$ \$ 4321,4332$ (2000) (requiring that environmental impact statements and comments be made available to the public).

${ }^{89}$ Id. $\$ \S 4321,11,001,11,044$ (a).

90 See Kaswan, supra note 84, at 286-89 (suggesting that some environmental laws establish substantive criteria such that violation may signal a possibly discriminatory decision).

91 See Reich, supra note 79, at 297-98.

92 See, e.g., Foreman, supra note 40, at 124; Michael S. Greve, Environmental Justice or Political Opportunism, 9 ST. John's J. Legal Comment. 475, 479 (1994); J.B. Ruhl, The Co- 
such criticisms of the movement assert that it lacks real substantive content.

Of course, environmental justice activists would disagree. While in its early stages environmental justice was understood as a term synonymous with "environmental racism," suggesting its primary focus on race discrimination issues, ${ }^{93}$ it has become clear that its focus is much broader than that. Since then it has reached out to poor Caucasian communities and others concerned with environmental degradation. In many respects it is as much a social justice movement focused on environmental matters as the civil rights movement was with respect to the racial subordination of African-Americans. Its concerns have included socio-economic disparities, the exclusion of minorities and the poor from decision-making processes, and the current effects of past discrimination and other past wrongs. ${ }^{94}$ Implicit is a more general interest in ensuring an environment that promotes the economic health and quality of life needs and desires of racial minorities and the poor. ${ }^{95}$

These conflicting views should not be surprising. They spring from disagreements about what the environmental justice movement stands for and what its goals are. After all, "justice" is a term that is

Evolution of Sustainable Development and Environmental Justice: Cooperation, Then Competition, Then Conflict, 9 Duke Envtl. L. \& Pol'y. F. 161, 185 (1999) ("Environmental justice uses equity as the theme for a narrow, single-minded focus on eliminating disproportionate impacts of environmental degradation on racial minorities at site-specific levels."). Equally critical assertions have been that environmental justice is more about jobs, lack of political power, and tax trade offs than racial discrimination. David Schoenbrod, Environmental 'Injustice' Is About Politics, Not Racism, WALL St. J., Feb. 23, 1994, at A21.

93 Rev. Benjamin F. Chavis, Jr., Foreword, in Confronting Environmental Racism: VoICES From THE GRAsSroots, supra note 39, at 3. According to then-Reverend Benjamin Chavis:

Environmental racism is racial discrimination in environmental policymaking $\ldots$ in the enforcement of regulations and laws ... in the deliberate targeting of communities of color for toxic waste facilities ... in the official sanctioning of the life-threatening presence of poisons and pollutants in communities of color ... [and] in the history excluding people of color from the mainstream environmental groups, decision-making boards, commissions, and regulatory bodies.

Id.

94 See generally Kuehn, supra note 73 (elaborating on corrective, distributional, procedural, and social justice aspects of environmental movement's goals).

95 In this respect, the environmental justice movement is concerned, as is critical race theory, with discriminatory structures and institutions. See, e.g., Richard Delgado, Introduction, in Critical Race Theory: The Cutting Edge, at xiii, xiii-xv (Richard Delgado ed., 1995); Cornel West, Foreword, in Critical Race Theory: The Key Writings That Formed The Movement, at xi, xi-xii (Kimberlé Crenshaw ed., 1995). 
used in a variety of contexts, ranging from notions of procedural justice to substantive ones, which has different meanings to different people. The concept of environmental justice is no different. ${ }^{96}$

Still, there are limits to an appropriate understanding of the concept of environmental justice. Because it is a term that has described the goals of environmental justice activists, attempting to study an abstract meaning runs the risk of changing the concept into one divorced from what these activists intended it to capture and what they hoped to achieve. It should be apparent that a conception of "environmental justice" that is different from that of the movement will be significantly less useful, or of no use, in understanding the difficulties of integrating the movement's concerns into the existing environmental regulatory framework.

But there has been an aspect of the criticisms of the social justice understanding of environmental justice that is more difficult to address. Seeing environmental justice as a symptom of a larger struggle about political disenfranchisement has led activists to pursue a broad strategy of seeking political empowerment and increased participation by the poor and racial minorities in environmental decisions. ${ }^{97}$ This strategy's clarity and simplicity has provided the movement with a powerful organizing tool and appears to have been responsible for much of its successes to date. Yet, the simplicity of this process-based focus arguably has provided little guidance to industry and regulators interested in acting responsibly with regard to environmental justice issues and concerned with usable substantive decision-making criteria.

Unsympathetic criticisms in this regard have focused on the perception that environmental justice is an amorphous concept with no clear substantive contours and no clear regulatory goals. ${ }^{98}$ Most gen-

96 Differences and disagreement about the content and scope of the concept have been typical of efforts to define and gain a better understanding of environmental justice. See generally Andrew Dobson, Justice and the Environment: Conceptions of EnvironMental Sustainability and Dimensions of Social Justice 1, 5-7 (1998); Been, supra note 35; Kuehn, supra note 73, at 10,683-84; Ruhl, supra note 92, at 185.

97 See Luke W. Cole, Empowerment as the Key to Environmental Protection: The Need for Environmental Poverty Law, 19 Ecology L.Q. 619, 639-41 (1992) (suggesting that grassroots activists are willing to explore a wider range of strategies than mainstream environmentalists); Sheila Foster, Justice from the Ground Up: Distributive Inequities, Grassroots Resistance, and the Transformative Politics of the Environmental Justice Movement, 86 CAL. L. REv. 775, 808-09 (1998) (advocating that grassroots struggles are a crucial arena for restructuring social relations in systems of localized government decision-making).

${ }^{98}$ FOREMAN, supra note 40 , at 123 . Foreman asserts that “[e]nvironmental justice cannot yet be described as a clear, durable and primary goal for any national agency or significant interest group." Id. at 122. 
erally stated, the argument asserts that, the failure to articulate the contours of environmental justice clearly and specifically is a fatal defect that destroys any basis for reasoned government action by regulators. ${ }^{99}$ Some critics have maintained that the environmental justice movement has only been able to maintain public support for its goals by dealing in vague generalities, buzz words, and slogans ${ }^{100}$-that the movement is nothing but rhetorical flair. If forced to articulate more specifics than mere platitudes, ambiguities, and abstract concepts, the movement would simply collapse under its own contradictions and internal inconsistencies. ${ }^{101}$ In the eyes of these critics, the movement has contributed little to advancing solutions, and may arguably be an impediment to real progress on environmental protection issues for people of color. ${ }^{102}$

While there may be some truth to some of these concerns, such criticisms prove too much. After all, the faults that such critiques find with the movement also apply to the idea of racial and class justice more generally. Such arguments in essence deny that the civil rights movement and other social justice movements have accomplished significant social change. They ignore the successes of such movements in furthering the ideals of justice. The critics posit, in the end, that our present conceptions of justice are imperfect and that the make-shift tools used to pursue them have undesirable side-effects. That is, of course, a characteristic of ongoing philosophical and legal discourse about the meaning of social justice and its translation into concrete public policy measures.

Perfection and logical consistency remain in the realm of mathematics and other spheres of logical thought, but are unlikely to be achieved in the messy world of real life that the law is designed to handle. ${ }^{103}$ In that sense, attempts to engage in exercises of logic with

99 See id. at 3, 122-26.

100 See, e.g., Greve, supra note 92, at 479 (suggesting that while environmental justice may be powerful at the rhetorical level, it loses power at the practical level).

101 See generally Foreman, supra note 40, at 124. According to Christopher Foreman, "[b]eyond the conviction that rigorous democratic practice and accountability are essential to a just outcome," the movement "really specifies no answer to the question of what is best for a given community." Id.

102 Id. at 117 (arguing that environmental justice can deflect attention from serious hazards to less serious or perhaps trivial ones). In fact, one critic has stated that "[c]learly, no serious advances can be made in the attempt to pursue environmental equity until a conception of equitable distribution is crystallized." Lynn E. Blais, Environmental Racism Reconsidered, 75 N.C. L. REv. 75, 80 (1996).

103 Cf. Oliver Wendell Holmes, The Common Law 1 (1881) ("The life of the law has not been logic: it has been experience."). 
regard to environmental justice and its implementation in the law, in the vein of nineteenth century Langdellian legal views, ${ }^{104}$ demand a degree of articulation, consistency, and perfection of the movement that is not present in any other area of law and public policy. To accept environmental justice as an evolving concept means that any evaluation of it must consider that the imperfections of existing jurisprudential and philosophical frameworks also limit the full articulation of the movement's ideas. In determining the movement's success in accomplishing its goals, we must take into account real-world constraints. ${ }^{105}$

Yet, even given such limitations, it is possible to provide a more specific articulation of the substantive concerns of the environmental justice movement as they relate to environmental regulation. As discussed below, such an understanding focuses on the market failure parallels between discrimination and environmental degradation and the rationality of discriminatory actions.

\section{EPA's Title VI Guidance}

As a remedy to the inadequacies of the existing civil rights and environmental laws in addressing environmental justice concerns, activists have looked to Title VI of the Civil Rights Act of 1964. ${ }^{106}$ Title VI prohibits discrimination by recipients of federal financial assistance. ${ }^{107}$ While the Supreme Court has held that Title VI itself only directly reaches constitutionally prohibited, intentional forms of discrimination, it has also acknowledged that Title VI allows federal agencies to promulgate implementing regulations that prohibit actions with unjustifiably disparate impacts. ${ }^{108}$

${ }^{104}$ See generally Dennis Patterson, Langdell's Legacy, 90 Nw. U. L. REv. 196 (1995) (discussing Christopher Langdell's contributions to the conception of and approach to law).

${ }^{105}$ This is not to imply that activists have a proprietary interest in the meaning and the goals of environmental justice or that there is necessarily unanimous agreement among all activists on the meaning and goals of the movement-it is an ideal that belongs to all. Nor does it mean that one cannot examine the movement critically. Yet, unless we believe that environmental justice is a sham issue-that is, it is just window-dressing for self-interested actions-we must first understand and accept environmental justice under the movement's own terms in order to critique it in a meaningful fashion. To determine what it has contributed to our understanding about the role of race and class in environmental regulation, we must take the beliefs and goals of environmental justice advocates seriously.

10642 U.S.C. $\$ \S 2000 \mathrm{~d}-2000 \mathrm{~d}-7$ (2000).

${ }^{107} \mathrm{Id}$.

${ }^{108}$ See Alexander v. Choate, 469 U.S. 287, 292-93 (1985) (defining the Court's earlier two-pronged holding on the nature of the discrimination proscribed by Title VI as expressed in Guardians Ass'n v. Civil Service Comm'n, 463 U.S. 582, 584, 607-08 (1983)). 
The vast majority of states and local governments receive some form of federal financial assistance from EPA for their environmental programs and are, accordingly, subject to the mandates of Title VI. Because EPA's Title VI implementing regulations ${ }^{109}$ incorporate the disparate impact standard, they were originally expected to make it significantly easier for environmental justice activists to vindicate their claims. ${ }^{110}$ Moreover, as a more informal administrative process, this mechanism was thought to be able to provide substantial assistance in investigating and gathering proof. ${ }^{111}$ The reality has not borne out such hopes. ${ }^{112}$

109 EPA's Title VI regulations, which require non-discrimination in programs receiving federal assistance from the EPA, provide in part:

A recipient shall not use criteria or methods of administering its program which have the effect of subjecting individuals to discrimination because of their race, color, national origin, or sex, or have the effect of defeating or substantially impairing accomplishment of the objectives of the program with respect to individuals of a particular race, color, national origin, or sex . . . A recipient shall not choose a site or location of a facility that has the purpose or effect of excluding individuals from, denying them the benefits of, or subjecting them to discrimination under any program to which this part applies on the grounds of race, color, or national origin or sex; or with the purpose or effect of defeating or substantially impairing the accomplishment of the objectives of this subpart.

40 C.F.R. $\$ \$ 7.35$ (b) \& (c) (2001). These regulations have become especially important in the environmental regulatory context because many state and local environmental programs receive financial assistance from EPA and thus are subject to the discriminatory impact standard. See Steven Light \& Kathryn Rand, Is Title VI a Magic Bullet?: Environmental Racism in the Context of PoliticalEconomic Processes and Imperatives, 2 Mich. J. RACE \& L. 1, 26 (1996).

110 See, e.g., James H. Colopy, The Road Less Traveled: Pursuing Environmental Justice Through Title VI of the Civil Rights Act of 1964, 13 STAN. ENVTL. L.J. 125, $180-85$ (1994).

111 See, e.g., Luke W. Cole, Civil Rights, Environmental Justice and the EPA: The Brief History of Administrative Complaints Under Title VI of the Civil Rights Act of 1964, 9 J. ENVTL. L. \& LiTig. 309, 320 (1994).

112 In fact, EPA has been excoriated for its glacial pace in processing such complaints as well as the single substantive decision it has issued., Id. at 392-96. See generally Luke W. Cole, "Wrong on The Facts, Wrong on The Law": Civil Rights Advocates Excoriate EPA's Most Recent Title VI Misstep, 29 Envtl. L. Rep. 10,775 (1999); Colopy, supra note 110. Since the beginning of the Clinton Administration, 124 such complaints have been filed. U.S. EPA, Office of Civil Rights, Status Summary Table of EPA Title VI Administrative Complaints, Jan. 4, 2002, at http://www. epa.gov/ocrpage1/docs/t6stjun2000.pdf (last visited Jan. 16, 2002). Sixty-seven of them have been rejected on technical procedural grounds. Id. Only one complaint has been evaluated on the merits-the complainants lost. Id. Forty-six of the complaints continue to await resolution. Id. Yet, even these modest and tentative steps have been criticized strongly by business interests and state and local governments as simply unwarranted. See, e.g., Cindy Skrzycki, Up Against the Environmental Justice System, WASH. Post, Oct. 23, 1998, at F1. 
EPA originally issued its Title VI implementing regulations in 1973 and revised them in $1984 . .^{113}$ Beginning in the early 1990s, environmental justice groups began to press EPA to make more effective use of its Title VI regulations. ${ }^{114}$ EPA, however, did not react substantively to these calls until 1998.115 Then, in order to facilitate its handling of administrative Title VI complaints, EPA issued an Interim Guidance setting out a number of procedural and substantive requirements governing its investigations of discriminatory impact complaints. ${ }^{116}$ At its core, it created a five-step process by which disparate impact allegations were to be analyzed. ${ }^{117}$ Yet, with all the delay and expectations, only one administrative Title VI complaint was decided on the merits- with an outcome adverse to the complainants. ${ }^{118}$

On June 27, 2000, EPA issued draft guidance documents to clarify for agencies and citizens the compliance requirements of Title VI of the Civil Rights Act of $1964 .{ }^{119}$ Set out in two parts, the first directs itself to recipients of EPA financial assistance. ${ }^{120}$ This "Draft Recipient Guidance" seeks to aid federal fund recipients to avoid Title VI complaints through "a framework designed to improve ... existing programs or activities and reduce the likelihood or necessity for persons to file Title VI administrative complaints." ${ }^{121}$ Its recommendations to recipients include measures regarding staff training, public participation and outreach, disparate impact analyses, intergovernmental in-

113 See 40 C.F.R. $\$ \S 7,12$ (2001).

114 See Cole, supra note 111, at 392-97.

115 See generally Cole, supra note 112, at 10,775.

116 U.S. Envtl. Protection Agency. EPA, Interim Guidance for Investigating TIthe VI Administrative Complaints Challenging Permits (Feb. 5, 1998), at http:// www.epa.gov/civilrights/docs/interim.pdf (last visited Jan. 16, 2002) [hereinafter INTERIM GuIDANCE].

117 These steps include: (1) identification of the affected population; (2) determining the demographics of the affected population; (3) determining the universe(s) of facilities and total affected population(s); (4) conducting the disparate impact analysis; and (5) determining the significance of the disparity. See INTERIM GuIDANCE, supra note 116.

118 Letter from Ann E. Goode, U.S. EPA, Office of Civil Rights, to Father Phil Schmitter, Sister Joanne Chiaverini, St. Francis Prayer Center, and Russell J. Harding, Michigan Department of Environmental Quality, re: EPA File No. 5R-98-R5 (Select Steel Complaint) (Oct. 30, 1998) (on file with author), available at http://www.epa.gov/region5/steelcvr. htm (last visited Jan. 16, 2002) [hereinafter Select Steel Complaint Letter]. 39,650 .

119 Draft Title VI Recipient and Revised Investigation Guidance, supra note 17, at

120 See id. at 39,655 .

121 Id. 
volvement, alternative dispute resolution, mitigation measures, and internal evaluations of Title VI activities. ${ }^{122}$

The second part, the "Draft Revised Investigation Guidance," describes and elaborates upon the investigative process EPA is to follow in pursuing complaints alleging disparate impacts from the issuance of a permit by a federal fund recipient. ${ }^{123}$ The Draft Revised Investigation Guidance includes a detailed procedural time-line setting out deadlines and other timeliness requirements for filing a complaint, ${ }^{124}$ intermediate decisions on acceptance or rejection of complaints, preliminary findings of non-compliance, voluntary compliance opportunities by the recipient, and appeals. ${ }^{125}$ In addition, it also sets out various substantive criteria and guidelines it plans to use in reviewing the merits of disparate impact complaints. ${ }^{126}$ At its heart is the adverse disparate impacts analysis, which is used to decide whether the environmental permit at issue creates an adverse disparate impact cognizable under its Title VI regulations and warrants further administrative action. ${ }^{127}$

This analytical framework consists of a six-step process that retains all of the elements elaborated upon in the Interim Guidance:128 (1) An assessment of the applicability of the Title VI regulations; (2) a determination of the appropriate scope of the investigation; (3) an evaluation of the actual impacts; (4) a determination of whether the impact is in fact adverse; (5) a demographic characterization of the affected population; and (6) a decision on whether the adverse disparate impact is sufficiently significant. ${ }^{129}$

122 See id. at $39,656-64$.

123 See id. at 39,668-69.

124 Under the Draft Revised Guidance, complaints must be filed within 180 days of the triggering discriminatory act, such as the issuance of a permit having discriminatory impacts. $I d$. at 39,672. During the pendency of a Title VI complaint, however, a contested permit remains in effect. $I d$. at 39,676 .

${ }^{125}$ All throughout the complaint process, EPA also encourages the informal settlement of complaints, including through alternative dispute resolution processes. Draft Title VI Recipient and Revised Investigation Guidance, supra note 17, at 39,673.

126 Id. at $39,676-82$.

127 Id.

128 The Draft Revised Guidance expands a five-step disparate impact analysis to a sixstep process by including and expanding on one criterion that was previously already part of the INTERIM GUIDANCE generally, but not as a specific impact analysis step. Compare INTERim GuIdANCE, supra note 116, at 7, with Draft Title VI Recipient and Revised Investigation Guidance, supra note 17, at 39,677.

129 Draft Title VI Recipient and Revised Investigation Guidance, supra note 17, at $39,676-77$. 
The Draft Revised Guidance's first step seeks to limit the set of applicable permit actions where EPA will pursue the substantive allegations of the complaint. ${ }^{130}$ For instance, EPA is likely to find its Title VI regulations inapplicable to permit actions that do not involve issues related to stressors identified in the complaint, such as changes of name or mailing addresses. ${ }^{131}$ EPA is also unlikely to act on complaints involving permits covered by area-specific agreements already determined by EPA to satisfy Title VI requirements, which lead to significant decreases of overall pollution emissions, or that involve permit actions that in fact significantly reduce the pollutants of concern to the complainant, are unlikely to pass this hurdle in the analysis. 132

The second step defines the scope of the investigation by focusing on which stressors, sources of stressors, and/or impacts have been appropriately raised by the complaint as implicating EPA's Title VI regulations. ${ }^{139}$

The third step then seeks to establish a causal link or association between the alleged discriminatory act and the alleged discriminatory impacts. ${ }^{134}$ Such a determination is to include an inquiry into plausible mechanisms and exposure routes between the impacts and the source of stressors as well as attempts to quantify such potential impacts. ${ }^{135}$ In doing so, EPA expects to examine the various causal links to the impacts, the risks that various exposures and stressors create, and the toxicity and concentration levels of particular stressors. ${ }^{136}$

The fourth step of EPA's Draft Investigation Guidance calls for an assessment of whether the impacts are in fact adverse as an environmental or human health matter. ${ }^{137}$ Such a determination is made by

130 Id. at 39,677 .

${ }^{131}$ According to the Draft Revised Guidance, stressors are " $[\mathrm{g}]$ enerally, any substance introduced into the environment that adversely affects the health of humans, animals, or ecosystems." Id.

${ }_{132} \mathrm{Id}$, at 39,675-76. In area-specific agreements, recipients enter into agreements with affected residents and local stakeholders to proactively address pollution burdens in geographic areas where adverse disparate impacts may already exist. Id. But for EPA to extend deference to such agreements, such that they will affect its investigation of the complaint, the area-specific agreement must be supported by adequate Title VI analyses and be expected to result, within a reasonable time, in actual reductions or the elimination of Title VI cognizable impacts. See id.

193 Id. at $39,677-79$.

194 Id. at 39,679-80.

135 Draft Tite VI Recipient and Revised Investigation Guidance, supra note 17, at 39,679 .

${ }^{136}$ Id. at $39,679-80$.

${ }^{137}$ Id. at $39,680-81$. 
reference to various benchmark values provided by statutes, EPA regulations, or EPA policy. ${ }^{138}$ In general, exposures must exceed an established human health or environmental threshold value in order to satisfy this criterion. ${ }^{139}$ While EPA refers to this determination as an assessment of whether the impact is significantly adverse, the significance referred to here is not the same as the statistical or legal significance raised in step six. ${ }^{140}$

The fifth step calls for the identification and characterization of the population affected by the permit action in terms of race, color, and national origin. ${ }^{141}$ It also requires a determination of whether a disparity exists between the affected population and appropriate comparison populations. ${ }^{142}$ Because of differing exposure routes, various affected populations may be identified depending on the particular impacts raised in the complaint. ${ }^{143}$ Assessments that are made include comparisons between the impacts borne by these demographic populations and others, the demographic make-up of the affected population, and the average impacts and range of impacts. ${ }^{144}$

The sixth and final step examines whether the disparity is legally significant. ${ }^{145}$ While this step appears to focus primarily on statistical measures of significance, it also evaluates associated demographics and types of impacts. ${ }^{146}$ For example, demographic information that EPA examines here includes affected population size, overall demographic composition, and the proportion of the jurisdiction's population in the affected population. ${ }^{147}$ Considerations related to the impacts and stressors themselves include the extent to which adverse impacts exceed significance thresholds, the severity of impacts, and the frequency of their occurrence. ${ }^{148}$

$138 I d$.

139 The Guidance is explicit in stating that compliance with national ambient air quality standards (NAAQS) presumptively satisfies the mandates of Title VI. $I d$. at 38,680-81. Likewise, where a permit action "clearly leads to a significant decrease in adverse disparate impacts," even if other emissions increase, such conditions are considered in the remedial actions proposed by EPA. Id. at 39,681 .

140 See infra notes 147-150 and accompanying text.

141 Draft Title VI Recipient and Revised Investigation Guidance, supra note 17, at 39,681 .

142 Id.

143 Id.

144 Id. $39,681-82$.

${ }^{145} I d$ at 39,682 .

146 Id.

147 Draft Title VI Recipient and Revised Investigation Guidance, supra note 17, at $39,682$.

148 Id. 
In proceeding through this analysis, EPA is to accord "due weight" to information submitted by recipients related to the disparate impact analysis. ${ }^{149}$ Such information could provide demographic information, analyses of environmental impacts, and other related evidence. ${ }^{150}$ In essence, "due weight" constitutes a means by which EPA extends some deference to the regulatory efforts of state and local government recipients similar to the deference EPA extends in other environmental regulatory programs. ${ }^{151}$ To ensure the reliability of the information submitted by states and local government recipients, however, such deference is conditioned on the relevance of the evidence, the validity of the methodology, the completeness of the information, the consistency of the methodology and the findings, and uncertainties in the input data and results. ${ }^{152}$ In the context of area-specific agreements, which may show reductions or elimination of disparate impacts or provide for a plan to do so, this deference could lead to a closure of EPA's Title VI investigation. ${ }^{153}$

A finding of a significantly adverse disparate impact, however, does not mean that the complainant has prevailed. ${ }^{154}$ Upon such a finding, recipients have the opportunity to provide rebuttal evidence. ${ }^{155}$ If the rebuttal evidence does not change the finding, recipients may also justify their permit action notwithstanding the adverse disparate impact. ${ }^{156}$ Thus, significant adverse disparate impacts may be permissible if they are "reasonably necessary to meet a goal that is legitimate, important, and integral to the recipient's institutional mission." 157 This can include interests in economic development arising out of a permit action "if the benefits are delivered directly to the affected population." 158 Yet, if a less discriminatory alternative to the permit action exists, such an alternative would rebut the justification itself. ${ }^{159}$ After all, a less discriminatory alternative that still meets the

149 Id. at 39,675 .

${ }_{150}$ See id. at 39,674 .

151 See id.

$152 \mathrm{Id}$. at 39,675 . 39,675 .

153 Draft Title VI Recipient and Revised Investigation Guidance, supra note 17, at

154 See id. at $39,683-84$.

${ }_{155}$ Id. at 39,683 .

${ }_{156} I d$

157 Id.

${ }^{15 \theta} I d$.

${ }^{159}$ See Draft Title VI Recipient and Revised Investigation Guidance, supra note 17, at 39,683. A less discriminatory alternative constitutes an "approach that causes less disparate 
needs addressed by the discriminatory action, such as practical mitigation measures, would make the challenged action unnecessary.

It is only at this point that EPA's Title VI process moves into the remedies phase. ${ }^{160}$ EPA may seek the recipient's acquiescence to the finding and its voluntary compliance with its proposed remedial measures. ${ }^{161}$ If voluntary compliance is not possible, however, EPA may also pursue more coercive measures, such as commencing formal proceedings "to deny, annul, suspend, or terminate EPA assistance."162 In such an event, the recipient may seek review and appeal of the decision through EPA's administrative adjudicative process. ${ }^{163}$

By providing a detailed framework, the two-part Draft Revised Guidance, EPA has sought to clarify many ambiguities found in the Interim Guidance. ${ }^{164}$ Yet, in spite of the increased detail, the Draft Revised Guidance has not resolved many of the uncertainties in how EPA will address future Title VI complaints. ${ }^{165}$ These uncertainties have left EPA with considerable flexibility and discretion. ${ }^{166}$ They also make it somewhat difficult to predict how helpful the Draft Revised Guidance will be in facilitating the resolution of Title VI complaints in a fashion more favorable to environmental justice groups. Nevertheless, a critical evaluation, based on the approaches and methodologies used in the Draft Revised Guidance, is possible and provides important insight into its prospects.

\section{EPA's Title VI Guidance and the Tensions Between the Regulatory Premises of Environmental LaW and Givil Rights LaW: The Form of ENVIronmental Justice}

Similar to the controversy surrounding EPA's Interim Guidance, serious criticisms were again raised by the environmental justice

impact than the challenged practice, but is practicable and comparably effective in meeting the needs addressed by the challenged practice." Id.

$160 \mathrm{Id}$.

161 Id.

162 Id. at 39,684. Under Title VI, EPA may also refer a finding of non-compliance to the Department of Justice for judicial enforcement. 40 C.F.R. $\$ 7.130$ (a).

163 Draft Title VI Recipient and Revised Investigation Guidance, supra note 17, at $39,683-84$.

164 Id. at 39,651 .

165 See Bradford C. Mank, The Draft Title VI Recipient and Revised Investigation Guidances: Too Much Discretion for EPA and a More Difficult Standard for Complainants?, 30 Envtl. L. Rep. 11,144 (2000).

166 See id. 
community with respect to the Title VI Draft Revised Guidance. ${ }^{167}$ That should not have been surprising. Many of the difficulties that EPA has faced in addressing environmental justice more generally are traceable to the different premises about the role of government intervention in solving environmental justice problems-environmental regulators bringing with them understandings based on the traditional environmental regulatory system, and environmental justice activists viewing the issues based on perspectives shaped by civil rights law. ${ }^{168}$ In the Title VI context, these unresolved differences are especially pronounced since EPA is explicitly seeking to merge the mandates of a civil rights statute into its environmental regulatory framework. ${ }^{169}$

Viewing the difficulties in this fashion may seem odd for many since it calls for a comparative examination between environmental law and civil rights law. After all, the two systems appear to address fundamentally different subject matters-the management and preservation of the quality of the human environment as opposed to racial equality and individual rights. Moreover, when one thinks of civil rights law in action, one thinks of judicial intervention, which is primarily associated with the ad hoc resolution of particular disputes among private individuals or entities. Environmental law appears instead to be primarily concerned with the administration of public programs that affect many or all of the citizenry beyond the immediate parties to the dispute. ${ }^{170}$ Important congressional statutes exist with regard to civil rights and environmental protection. ${ }^{171}$ However, the interstices of civil rights law are filled primarily by courts through case-by-case adjudication, rather than by administrative regulation. The predominance of courts and common law adjudication has thus

${ }^{167}$ See, e.g., Letter from Luke Cole, supra note 20; Public Comments on Draft Revised Guidance, supra note 20.

168 See Yang, supra note 24, at 20-22.

169 See U.S. Envtl. Protection Agency, Environmental Justice, at http://es.epa. gov/oeca/main/ej/index.html (last visited Jan. 16, 2002).

170 Civil rights law is not devoid of administrative agencies. For instance, the Equal Employment Opportunity Commission (EEOG) or the Department of Housing and Urban Development (HUD) are important actors in the implementation of anti-discrimination law. Yet, rather than dominating the legal landscape, as EPA does in environmental law, administrative agencies play rather minor roles in civil rights law compared to the courts in shaping the substantive legal rules. See infra note 317 and accompanying text.

171 See, e.g., Clean Air Act, 42 U.S.C. $\$ \$ 7601-7671 q$ (2000); CERCLA, 42 U.S.C. $\$ \S 9601-9708$; Fair Housing Act, 42 U.S.C. $\$ \$ 3601-3619$; Civil Rights Acts, 42 U.S.C. $\S \S 1981-2000 \mathrm{~h}-6$. 
characterized much of civil rights law. ${ }^{172}$ Thus, comparing environmental law to civil rights law might seem like comparing apples to oranges.

Some scholars, such as Cass Sunstein, however, have drawn the parallels with little hesitation. ${ }^{173}$ In fact, the environmental protection system's common law roots in trespass and nuisance doctrines should give some indication that dismissing the common law as a regulatory regime would be overly simplistic. ${ }^{174}$ Thus, judicial adjudication and the common law have been systems for the creation of public policy just as administrative agencies and, more generally, the legislature have been. ${ }^{175}$ When congressional legislation sets broad policy objectives and few specific standards and rules, common law adjudication is more similar to the tasks of administrative agencies: filling in the interstices and ambiguities of congressional statutes. ${ }^{176}$ Judicial lawmaking is then confined within those broad policy and legal mandates.

The true distinction between courts and legislatures "is not that courts interpreting statutes do not 'legislate' at all, but that, in comparison with legislative assemblies, [courts] perform their function within a different institutional framework, by different procedures, and with a different kind of participation accorded to those who are affected by their decisions. "177 In the end, even though the operational modes of judicial adjudication and administrative decision-

172 See infra notes 305-321 and accompanying text. Discrimination suits seeking structural reform of institutions, such as school desegregation litigation, have pushed the courts outside of their traditional bipolar adjudicative modes. Abram Chayes, The Role of the Judge in Public Law Litigation, 89 Harv. L. Rev. 1281, 1284 (1976); see Peter A. Appel, Intervention in Public Law Litigation: The Environmental Paradigm, 78 WASH. U. L.Q. 215, 215 (2000). Yet, such instances remain the exception and are notable precisely because of their exceptional nature.

173 See, e.g., Cass R. Sunstein, After the Rights Revolution: Reconceiving the Regulatory State 61-64, 67-69 (1990) [hereinafter Sunstein, After the Rights Revolution]. See generally Cass R. Sunstein, Using Common Law Principles in Regulatory Schemes (With a Note on Victimology), 19 HaRv. J.L. \& PUB. PoL'y 651 (1996) [hereinafter Sunstein, Using Common Law Principles in Regulatory Schemes].

${ }^{174}$ In fact, several scholars have sought to revive interest in the common law as a means of solving environmental problems. See generally The Common LAW AND THE EnviRONMENT: Rethinking The Statutory Basis For MOdERn Environmental. Law, at xi24 (Roger E. Meiners \& Andrew P. Morriss eds., 2000).

175 Holmes, supra note 103, at 35-36.

176 See Andrew McFee Thompson, Free Market Environmentalism and the Common Law: Confusion, Nostalgia, and Inconsistency, 45 EMORY L.J. 1329, 1371 (1996) (stating that common law "functions as a meaningful supplement to statutory law").

177 Lon L. Fuller, ANatomy of THE LAW 102 (1968). 
making may be different, their overall function is the same: to serve as mechanisms for social ordering among people, and between their government. ${ }^{178}$

Considered in this light, an examination of the different institutional frameworks can provide much insight into serious problems raised by EPA's Title VI Draft Revised Guidance and its ability to address environmental justice complaints. ${ }^{179}$ In particular, it shows how different premises about minority protection, the significance of incommensurable values, and the scope of regulation have created tensions that threaten to undermine the effectiveness of EPA's efforts with regard to environmental justice.

\section{A. The Primary Beneficiary of Regulation: Protecting Minorities and the Larger Collective}

\section{Protecting the Larger Collective from Environmentally Harmful Individual Actions}

One characteristic of environmental law has been its distinctly majoritarian orientation. ${ }^{180}$ In large part, this orientation can be attributed directly to the market failure understanding of environmental degradation. ${ }^{181}$ Under Garrett Hardin's explication of the Tragedy of the Commons, the quintessential concern of environmental regulation has been with actions by individuals that, while advantageous and beneficial to that particular individual, are harmful to the

178 Lon L. Fuller, The Forms and Limits of Adjudication, 92 HARv. L. Rev. 353, 357 (1978) (“[F]undamentally, . . . adjudication should be viewed as a form of social ordering, as a way in which the relations of men to one another are governed and regulated [because] ... an adjudicative determination will normally enter in some degree into the litigants' future relations and into the future relations of other parties who see themselves as possible litigants before the same tribunal."). See Benjamin N. Cardozo, The Nature of THE Judicial Process 16, 20-21, 66, 98-141 (1949) (stating that an important task of the judiciary is "the filling of the gaps which are found in every positive law in greater or less measure[, which] you may call . . . legislation, if you will”); FuLLER, supra note 177, at 84-103.

179 Another important disjunction between the conceptions of environmental justice advocates and regulators about the role of public participation in regulation has been discussed elsewhere by Eileen Gauna. See generally Eileen Gauna, The Environmental Justice Misfit: Public Participation and the Paradigm Paradox, 17 STAN. ENvTL. L.J. 3 (1998) (arguing that communities bearing the most environmental risk participate in the administrative process the least).

180 See Gregory Daniel Page, Lucas v. South Carolina Coastal Council and Justice Scalia's Primer on Property Rights: Advancing New Democratic Traditions by Defending the Tradition of Property, 24 WM. \& MARY EnvTl. L. \& Pol'y Rev. 161, 209 (2000).

181 See generally Mark Sagoff, Economic Theory and Environmental Law, 79 Mich. L. Rev. 1393 (1981). 
community as a whole. ${ }^{182}$ Because everybody has access to and use of the commons, the failure of government to intervene with regulations results in the overuse and degradation of the commons. ${ }^{183}$ The regulatory consequence has been that environmental law is primarily directed at protecting the collective from the irresponsible or selfish actions of individuals or small groups. ${ }^{184}$

Modern environmental statutes reinforce the majoritarian focus forcefully through their design. ${ }^{185}$ Virtually none provides for recovery of benefits accruing to any individual. ${ }^{186}$ Awards of private damages are not permitted. ${ }^{187}$ Even the citizen-suit provisions of the environmental statutes follow in this mold. ${ }^{188}$ They create an important role for private actors in the environmental regulatory scheme by allowing individuals to step into the enforcement shoes of the government. ${ }^{189}$ As private attorneys general, citizens may in this fashion enforce the environmental laws against violators, sometimes even against the government itself. ${ }^{190}$ Any penalty monies that are paid by a defendant, unlike punitive damages, must be remitted to the Federal

182 Hardin, supra note 57.

183 See id.

184 See generally Yang, supra note 24.

185 See Sagoff, supra note 181, at 1398-99.

186 See id.

${ }^{187}$ Section 107 of the Comprehensive Environmental Response, Compensation, and Liability Act, allows private individuals to seek recovery of costs expended in cleaning up a hazardous waste site. 42 U.S.C. $\$ 9607$ (a) (2)(B) (2000). Such costs cover only "necessary costs of response." Id. Personal injury or other private damages are not included. See id. The Oil Pollution Act of 1990, is the lone exception in allowing for recovery of property and other economic damages. See Oil Pollution Act $\S 1002(b)(2), 33$ U.S.C. $§$ 2702(b) (2) (2000). It does not allow for personal injury damages. See id.

188 See, e.g., Meghrig v. KFC Western, Inc., 516 U.S. 479, 484-88 (1996) (holding that the citizen-suit provision under the Resource Conservation and Recovery Act (RCRA), 42 U.S.C. $\$ 6972$, does not allow recovery for the costs of cleanup); Gauna, supra note 80 , at 39-43 (noting that citizen-suit provisions "grant citizens the ability ... to sue on behalf of the community at large, rather than to vindicate individual rights").

189 See Gauna, supra note 179.

190 See id. It is tempting to compare citizen-suit provisions with private causes of actions that are found throughout federal statutes, including the civil rights statutes. Yet, such a comparison would be misleading. While injunctive relief as well as penalties may be obtained against the defendant, the very characteristic of private causes of action in the law, monetary damages or some other private benefit, is generally not provided for. The lack of monetary damages may be a source of significant constitutional standing difficulties for citizen-suit plaintiffs. See Cass R. Sunstein, What's Standing After Lujan ? Of Citizen Suits, "Injuries, " and Article III, 91 MicH. L. REv. 163, 232 (1992) (arguing that allowing successful citizen-suit plaintiffs to recover cash bounties would give them a concrete interest and therefore standing as well). 
Treasury. ${ }^{191}$ Furthermore, any judicial consent decrees that are entered into in settling citizen-suits are reviewed by the federal government to ensure that the decree is in the public interest and not the result of self-dealing by the litigants. ${ }^{192}$

The underlying majoritarian premise is also apparent in other important statutory tools that have sought to protect environmental interests. Thus, approaches to environmental regulation that have sought to provide for open decision-making and explicit consideration of environmental interests, ${ }^{193}$ as well as information dissemination about pollution and toxics, ${ }^{194}$ rest on the assumption that regulators and polluters will be more responsive to and take better care of environmental interests if they can be held accountable by political processes. Utilizing and enhancing political processes, of course, promotes majoritarian decision-making. ${ }^{195}$

Finally, there have also been institutional aspects that have contributed to this majoritarian focus. ${ }^{196}$ Chief among them is the reliance on administrative agencies to address environmental problems rather than courts. ${ }^{197}$ The greater prominence of agencies over courts is a consequence of the general necessities of dealing with modern social problems as well as the specific technical expertise requirements of managing environmental problems. ${ }^{198}$ Administrative agencies are able to develop the necessary technical skills and expertise and, at the same time, integrate many other non-legal considerations, such as social and economic factors, into their decision-making. ${ }^{199}$

191 See United States v. Smithfield Foods, Inc., 982 F. Supp. 373, 374 (1997). Courts and EPA have sought to make innovative use of supplemental environmental projects (SEPs), projects in which the defendant engages in environmentally beneficial activity as a form of injunctive relief, avoiding penalty payments swallowed up in the black hole of the Federal Treasury. A quid pro quo reduction of penalties for SEPs is prohibited. See id.

192 See, e.g., Federal Water Pollution Control Act $\$ 505$ (c)(3), 33 U.S.C. $\$ 1365$ (c) (3) (2000) ("No consent judgment shall be entered in an action in which the United States is not a party prior to $\mathbf{4 5}$ days following the receipt of a copy of the proposed consent judgment by the Attorney General and the Administrator.").

${ }^{193}$ E.g., National Environmental Policy Act (NEPA), 42 U.S.C. $\$ 4332$ (C) (2000).

${ }^{194}$ E.g., Emergency Planning and Community Right-to-know Act (EPCRA), 42 U.S.C. $\S 11044(2000)$.

195 See Sagoff, supra note 181, at 1414.

196 See Owen M. Fiss, Foreword: The Forms of Justice, 93 Harv. L. Rev. 1, 35 (1979).

197 See id.; see also Joshua Yount, The Rule of Lenity and Environmental Crime, 1997 U. CHI. LEGAL. F. 607, conclusion.

198 See generally Fred Bosselman \& A. Dan Tarlock, The Influence of Ecological Science on American Law: An Intraduction, 69 CHI.-KeNT L. Rev. 847, 863-69 (1994). See also RACHEL Carson, Silent Spring (1962).

${ }^{199}$ See generally Bosselman \& Tarlock, supra note 198, at 863-69. 
And since they are unhampered by the straight-jacket of ad hoc, formal judicial process, they can approach problems with a persistence and a focus that is necessary to develop rules on a systematic basis. As a result, the outcomes are best for all of society, rather than just the litigants. ${ }^{200}$ Thus, administrative processes promote the interests of the entire society rather than particular individuals or small groups.

\section{Protecting Racial Minorities from Discrimination and Exclusion by the Majority}

Environmental law's focus on protecting the larger collective is entirely reversed in civil rights law. Its institutional focus on racial minorities has led it to promote protections of minorities against discrimination, exclusion, and other unfair treatment by the majority. By its nature, civil rights law is largely counter-majoritarian in character. ${ }^{201}$

Its institutional structure is also supportive of this focus. Civil rights law has not seen the whole-sale technocratic regulatory transformation that has occurred in environmental regulation. To be sure, Congress has enacted a series of important federal statutes that have sought to federalize much of this area of the law. ${ }^{202}$ It has not, however, engaged in the large-scale delegation of congressional authority to modern expert agencies as it has in the environmental context. ${ }^{203}$ Instead, regulation in the civil rights context and the elaboration and interpretation of statutory rules continues to occur primarily through case-by-case adjudication by courts-law making and regulation in the

200 See generally James M. Landis, The Administrative Process $30-40$ (1938); SunSTEIN, AFTER THE Rights Revolution, supra note 173, at 11-73; JeRRY L. MASHAW ET AL., Administrative Law: The American Public Law System 5-7 (4th ed. 1998).

201 See United States v. Carolene Prods. Co., 304 U.S. 144, 152-53 n.4 (1938).

202 See, e.g., EISENBERG, supra note 69.

${ }^{203}$ For example, both the EEOC and HUD have responsibility only for oversight and enforcement against employment discrimination and housing discrimination, respectively. Furthermore, the EEOC does not have the "authority to promulgate rules or regulations pursuant to" Title VII. Gen. Elec. Co. v. Gilbert, 429 U.S. 125, 141 (1976). Its scope of authority, even within the limited realm of employment discrimination law that it does administer, is thus drastically narrower than that of EPA. Likewise, until the Fair Housing Amendments Act of 1988, HUD did not have the authority to bring general enforcement actions, nor address housing discrimination complaints through administrative adjudicatory actions. While the 1988 Amendments changed that, Pub. L. No. 100-430, 102 Stat. 1619 (codified as amended at 42 U.S.C. $\$ \$ 3601-3619,3631$ (1988)), HUD's authority within the housing discrimination laws remains substantially less than that of EPA within the environmental laws. See generally U.S. Commission on Civil Rights, The Fair Housing AMENDMENTS ACt OF 1988: The ENFORCEMENT Report 8-24 (1994). 
traditional common law mold. ${ }^{204}$ Judges, of course, by virtue of their professional traditions and life tenure in the case of the federal judiciary, have much greater insulation from normal political pressures than administrative agencies. Given that the purpose of the civil rights laws is to protect minority groups from majority oppression, countermajoritarian institutions, such as the courts, are more appropriate guardians of minority interests than institutions that are subject to political control, such as administrative agencies. ${ }^{205}$

\section{The Title VI Draft Revised Guidance's Reliance on Majoritarian Administrative Agency Processes to Protect Racial Minorities}

Given these antithetical approaches, it is not surprising that environmental justice activists have blamed the operation of environmental laws themselves as the cause of environmental injustice. ${ }^{206}$ To the extent that environmental decision-making is designed to advance the interests of the majority, it is natural for the minority to lose out when its interests come into conflict. 207

It should be noted that the problem of minority protections, while similar, is not the same as the problem of under-representation of broadly-held, unorganized, and diffuse interests within the administrative agency processes. ${ }^{208}$ As Richard Stewart once described it, modern administrative agency processes are more responsive to organized interests, and frequently also biased in favor of regulated interests because of their constant interactions and relationship with

204 At the same time, since the interests protected by civil rights laws have their roots and origins in the Constitution, the Supreme Court's influence has remained inordinately great. While its common law approach to case-by-case interpretation and elaboration of the law arguably governs only constitutional mandates, this approach appears to have naturally carried over to congressionally granted anti-discrimination rights. See generally Abram Chayes, Foreword: Public Law Litigation and the Burger Court, 96 HARv. L. REv. 4 (1982) (arguing that the Burger Court has sough t to fit issues concerning standing, class actions, and remedial discretion into the notions of traditional lawsuits); Henry P. Monaghan, Foreword: Constitutional Common Law, 89 Harv. L. Rev. 1 (1975); David A. Strauss, Common Law Constitutional Interpretation, 63 U. CHI. L. REv. 877 (1996) (interpreting constitutional law-making as common law); Kathleen M. Sullivan, Sins of Discrimination: Last Term's Affirmative Action Cases, 100 HARv. L. Rev. 78 (1986) (addressing the requirement of a culpable party).

${ }^{205}$ See generally Yang, supra note 24.

206 See generally id.

207 See BELL, supra note 15, at 158-94 (arguing through fictional account that society would be willing to trade the interests of racial minorities for the good of society, such as for a clean environment).

${ }^{208}$ Richard B. Stewart, The Reformation of American Administrative Law, 88 HARV. L. Rev. $1669,1760-90$ (1975). 
agency staff. ${ }^{209}$ At its most extreme, capture of an agency by its regulated interests may result. ${ }^{210}$ The agency becomes more concerned with protecting the interests of the entities that it is to police and regulate under its legislative mandate than with protecting the public interest. ${ }^{211}$

The difficulties that agency decision-making raises for minority groups appear to parallel such agency process failures. ${ }^{212}$ Yet, the parallel is misplaced. The premise of under-representation of broadlyheld and diffuse interests is that agency decision-makers do not adequately take such interests into account and thus undervalue the weight of such interests in their decision-making. ${ }^{213}$ The administrative process has failed to achieve the correct balancing of interests that provides the greatest benefit to all; in other words, the agency has made an error. ${ }^{214}$

The opposite is actually being asserted by environmental justice advocates. They have claimed that EPA has done too good a job of maximizing social utility at the expense of minority interests, interests that by definition have a lesser weight within such regulatory analysis. Thus, process safeguards, such as in the spirit of procedural due process protection or improved representation of interests, are unlikely to address such problems significantly. ${ }^{215}$ Instead, effective remedial actions will likely require substantive change in environmental decision-making criteria. ${ }^{216}$

One need not doubt EPA's sincerity with regard to environmental justice in order to be concerned about such systematic biases. As others have pointed out, scientific uncertainty remains in much of EPA's work, and alternative analytical approaches can easily be used to justify greatly contrasting regulatory outcomes. ${ }^{217}$ Thus, environmental justice complaints against a project might easily be disposed of through technical analyses and investigative results skewed in one di-

${ }^{209} \mathrm{Id}$. at $1713-15$.

210 See id. at 1714.

211 Id. at 1682-88, 1713-15.

212 Id. at $1787-88$.

213 Id.

214 Stewart, supra note 208, at 1787-88.

215 See generally Tseming Yang, Balancing Interests and Maximizing Rights in Environmental Justice, 23 VT. L. REv. 529 (1999).

216 Without substantive change, majoritarian-oriented administrative processes will simply perpetuate pre-existing inequalities. See Foster, supra note 97, at 826-41.

217 See, e.g., Robert R. Kuehn, The Environmental Justice Implications of Quantitative Risk Assessment, 1996 U. ILL. L. REv. 103 (1996); Richard Revesz, Environmental Regulation, CostBenefit Analysis, and the Discounting of Human Lives, 99 ColvM. L. REv. 941 (1999). 
rection or another. That may be especially true if the project involves a multi-million dollar industrial facility supported by the local congressional representative that is expected to bring much needed tax revenue, jobs, and economic development to the surrounding community.

This recognition points to a fundamental problem with regard to the majoritarian premise of EPA's Title VI Draft Revised Guidance. As the Guidance states, the administrative process for addressing Title VI discrimination complaints is purely an exercise of EPA's investigative and enforcement discretion. ${ }^{218}$ The Guidance itself is thus only an official description of how EPA plans to utilize that discretion:

It is important to note that EPA does not represent the complainants, but rather the interests of the Federal government, in ensuring nondiscrimination by [federal funding] recipients. The investigation of Title VI complaints ... should be viewed as OCR [EPA's Office of Civil Rights] following up on information that alleges EPA funds are being used inappropriately .... In addition, because the Title VI administrative process is not an adversarial one between the complainant and recipient, there are no appeal rights for the complainant built into EPA's Title VI regulatory process. ${ }^{219}$

The significant disadvantages of such a scheme for complainants should be clear. For instance, the lack of a specific and assured role for complainants within the administrative process once it has commenced is remarkable, given that one of the main complaints of environmental justice communities has been that they have traditionally been excluded from environmental decision-making processes. ${ }^{220}$ Complaining communities may of course provide EPA with information and help move the investigation along, ${ }^{221}$ but there is no recourse if EPA makes an adverse decision. ${ }^{222}$ In contrast, federal fund recipi-

218 See Draft Title VI Recipient and Revised Investigation Guidance, supra note 17, at 39,672 .

${ }^{219} \mathrm{Id}$.

220 See id. at 39,671-72.

${ }_{221} \mathrm{Id}$.

$222 \mathrm{Id}$. 
ents under investigation have the full panoply of administrative appeal and judicial review remedies available. ${ }^{223}$

The troubling preference for majoritarian processes also arises with respect to EPA's attempts to shunt complaints to informal and alternative dispute resolution processes. ${ }^{224}$ While such processes have been heralded as promoting less costly and speedier settlements of disputes, they also lack the protections that judicial and formal adjudicative proceedings provide a weaker party against the stronger one. ${ }^{225}$ Such informal proceedings perpetuate the unequal bargaining positions that minority communities and the poor find themselves in, which lead them to bring Title VI complaints in the first place. ${ }^{226}$ Utilizing a process that is plainly subject to political control and political pressure by industry interests is simply insufficient for interests that require counter-majoritarian protections. ${ }^{227}$

\section{The Role of States in EPA's Title VI Draft Revised Guidance}

The majoritarian premises of environmental law also point to the problematic role of state and local governments within the Title VI Guidance. Federal environmental statutes have created strong cooperative relationships between federal agencies and state and local governments. Oftentimes referred to as environmental federalism,

223 EPA is not unique as an agency in utilizing this investigative approach to ensure compliance with Title VI responsibilities. See 28 C.F.R. $\$ \S 42.101-.112$ (2001) (setting out Department of Justice regulations under Title VI). Yet, the approach is in many respects a departure from how EPA deals with administrative appeal rights in other contexts, which are arguably more appropriate models. For example, environmentalists and private citizens who raise concerns about EPA approval of pollution generating activities, as in the context of permitting decisions, may appeal if the administrative decision is adverse to them. See, e.g., 40 C.F.R. $\$ 124.19$ (2001) ("[A]ny person who filed comments on [a] draft permit [regarding RCRA, Underground Injection Control (UIC), National Pollutant Discharge Elimination System (NPDES), or Prevention of Significant Deterioration (PSD)] or participated in the public hearing may petition the Environmental Appeals Board to review any condition of the permit decision.").

224 See Draft Title VI Recipient and Revised Investigation Guidance, supra note 17, at 39,673-74.

225 See id.

226 See Letter from Luke W. Cole, supra note 20, and text accompanying notes 18-22; see also Eric $\mathrm{K}$. Yamamoto, ADR: Where Have the Critics Gone?, 36 SANTA Clara L. Rev. 1055, 1058-60 (1996) (stating that Alternative Dispute Resolution perpetuates and amplifies inherent inequalities in bargaining positions).

227 Prior to the Clinton Administration, EPA simply ignored or avoided addressing the relevance of social justice and equity concerns in its regulatory work. See DowIE, supra note 53, at 155-57; Gauna, supra note 80, at 18-19 \& nn.59-61. For EPA to implement measures, which have been taken by other agencies many years earlier, is troubling in light of its poor track record with environmental discrimination issues until recently. 
federal regulations cede significant control over environmental protection, via cooperative arrangements, to states and local governments. ${ }^{228}$ For example, both the Clean Air Act and the Clean Water Act look to states as the primary entities to set standards, administer, and enforce specific regulatory programs appropriate to the characteristics of their jurisdictions. ${ }^{229}$

This close cooperative relationship has historical roots. Traditionally, regulation of the environment, including pollution and natural resources, was a matter almost exclusively the subject of state common law. ${ }^{230}$ It was only through a gradual evolution of increased federal intervention, beginning with federal funding and other assistance for state and local government regulatory efforts and culminating in direct federal regulation, that the modern environmental regulatory system arose.

But there are also important functional and practical considerations for continued reliance on state and local governments in addressing environmental degradation problems. With an enormous range of activities that contribute to pollution and environmental regulation, the federal government simply does not have the resources to supervise and take responsibility for all of the regulatory actions needed to protect the environment. ${ }^{231}$ Since many environmental problems have primarily local effects, local and state government entities will often have faster and better access to information about pollution problems than the federal regulators. ${ }^{232}$ Cooperation with state and local governments in protecting the environment is simply necessary to achieve an effective system. ${ }^{233}$

228 See Robert V. Percival, Environmental Federalism: Historical Roots and Contemporary Models, 54 MD. L. REv. 1141, 1161, $1174-75$ (1995). Of course, the federal government sets minimum standards; see also Daniel C. Esty, Revitalizing Environmental Federalism, 95 MICH. L. REv. 570 (1996); Richard L. Revesz, Federalism and Interstate Environmental Externalities, 144 U. PA. L. Rev. 2341, 2342-43 (1996) (describing "interstate externalities" as a primary reason for environmental regulation at the federal level).

229 Clean Water Act, 33 U.S.C. $\$ 1251$ (2000); Clean Air Act, 42 U.S.C. $\$ 7410$ (2000); see also William Rodgers, JR., Environmental Law 196-210 (2d ed. 1994).

230 See generally THE COMmON LAW AND THE Environment, supra note 174. In regard to natural resources management, the states continue to retain their primary regulatory role, though the federal government's role has expanded considerably through acts such as the Endangered Species Act. See 43 C.F.R. \$ 24.3 (2001) (setting out Fish and Wildlife Service's general relationship to the states).

231 See Richard B. Stewart, Bramids of Sacrifice? Problems of Federalism in Mandating State Implementation of National Environmental Policy, 86 YALE L.J. 1196, 1199-1201 (1977).

232 See id.

233 See, e.g., id.; see also Richard Lazarus, The Tragedy of Distrust in the Implementation of Federal Environmental Law, 54 LAw \& ConTeMP. Probs. 311 (1991). Certainly, there are 
The relationship of the federal government to states and local government with regard to civil rights has been fundamentally different. Civil rights law has been based on the premise that the federal government must be suspicious of state and local government actions in regard to race. ${ }^{234}$ After all, adoption of the Reconstruction Amendments to the Constitution and passage of federal civil rights legislation occurred in response to state-sanctioned or state-mandated discrimination against racial minorities. ${ }^{235}$

That is not to say that states have been entirely missing from the implementation and enforcement of federal anti-discrimination laws. ${ }^{236}$ In fact, states may and frequently do, as in the environmental context, provide greater protections under their own legislative authority. ${ }^{237}$ It seems hardly appropriate, however, for the federal government to vest trust in entities that it is also obligated to strictly police. The result has been that the cooperative scheme, such as "delegation" of substantive regulatory authority, and the deference that is accorded to state regulatory actions in the federal environmental scheme, is largely missing in the federal civil rights scheme.

Increasing historical distance to segregation and other governmentally-sanctioned forms of discrimination does raise the question whether such distrust is still warranted. Especially in a context where

aspects of environmental protection where federal government agencies may be at an advantage over state and local governments. Technical expertise or the availability of agency resources are some of those advantages. At a minimum, however, the capabilities of local and state governments as well as their responsiveness to citizens means that they have a legitimate and important role in environmental protection alongside the federal government.

234 Built upon this rationale and history, Congress received special powers through Section Five of the Fourteenth Amendment to enforce its provisions, while limiting the power of the states to act in race matters. See, e.g., Adarand Constructors v. Pena, 515 U.S. 200, 255 (1995) (Stevens, J., dissenting) ("It represents our nation's consensus, achieved after hard experience through our sorry history of race relations, that the Federal Government must be the primary defender of racial minorities against the States, some of which may be inclined to oppress such minorities."); see also City of Richmond v. J.A. Croson Co., 488 U.S. 469, 490 (1989) (stating the " $[t]$ he Civil War Amendments ... worked a dramatic change in the balance between congressional and state power over matters of race ... . They were intended to be ... limitations of the powers of the States and enlargements of the power of Congress." ) (citations omitted).

${ }^{235}$ This reason for intervention is thus quite different from that prompting federal involvement in environmental issues. Rather than being triggered by the inability of states to overcome their collective action problems, federal involvement in civil rights protections was necessitated by the complicity and active misdeeds of state governments.

${ }^{236}$ See, e.g., 42 U.S.C. $\$ 3610$ (f) (2000) (identifying the referral process to state and local agencies).

${ }_{237}$ See, e.g., Railway Mail Ass'n v. Corsi, 326 U.S. 88, 93-94 (1945). 
cooperation by the federal government with state and local entities has occurred successfully for quite some time, one might ask whether such cooperation might also occur successfully with regard to civil rights. However, even conservatives, such as Justice Scalia, have emphasized that distrust of states and local governments continues to be justified not only as a matter of Fourteenth Amendment history, however, but also as a matter of social reality and governmental theory.

[T] he record shows ... that racial discrimination against any group finds a more ready expression at the state and local than at the federal level .... The smaller the society, the fewer probably will be the distinct parties and interests composing it; the fewer the distinct parties and interests, the more frequently will a majority be found of the same party; and the smaller the number of individuals composing a majority, and the smaller the compass within which they are placed, the more easily will they concert and execute their plan of oppression. Extend the sphere and you take in a greater variety of parties and interests; you make it less probable that a majority of the whole will have a common motive to invade the rights of other citizens; or if such a common motive exists, it will be more difficult for all who feel it to discover their own strength and to act in unison with each other. 238

It is this tension that underlies the problem of state and local government participation in the Title VI administrative complaint process of EPA. State and local governments have sought some amount of deference or protection from EPA Title VI administrative complaints if appropriate state environmental justice programs are in place. ${ }^{239}$ While initially indicating that it would not extend any deference to states as part of its Title VI process, ${ }^{240}$ its Draft Revised Guid-

238 City of Richmond v. J.A. Croson Co., 488 U.S. 469, 522-23 (1989) (Scalia, J., concurring) (quoting The Federalust No. 10, at 82-84 (C. Rossiter ed., 1961) (citations and quotations omitted)). This applies not only to discrimination against racial minorities but also to the burdens that other disenfranchised groups, such as the poor, face more generally. See, e.g., Robert W. Collin \& William Harris, Sr., Race and Waste in Two Virginia Communities, in Confronting ENvironmental Racism: VoIces fROM THE Grassroots, supta note 39, at 93; Foster, supra note 97, at 808-09.

239 See EPA Civil Rights Policy Will Not Defer to State Equity Programs, Inside EPA WeEkLy RePORT, Apr. 21, 2000, at 19-20.

240 See National Advisory Council for Environmental Policy and Technology, RePort of the Title VI Implementation Advisory Committee: NeXt Steps for EPA, 
ance accords "due weight" to analysis and data provided by states related to a disparate impact analysis as well as area-specific agreements that are designed to eliminate or reduce adverse disparate impacts in those areas. ${ }^{241}$ That is, of course, problematic if the state and local government is the target of a Title VI disparate impact claim.

EPA's scope of inquiry with regard to disparate impacts ${ }^{242}$ is equally problematic. The Guidance largely limits the scope of considered impacts and stressors to those that "are within the recipient's authority to consider, as defined by the applicable laws and regulations. ${ }^{243}$ This seems to imply that Title VI imposes no independent anti-discrimination requirements outside of the recipient's legal authority, a proposition that seems to run counter to most civil rights law. 244

Of course, there is considerable ambiguity as to whether "applicable laws and regulations" only means state laws or also includes other federal laws, such as Title VI itself. ${ }^{245}$ The statement is, at best, a tautology that recipients will have to consider all impacts and stressors that Title VI requires them to consider-essentially that recipients must comply with all laws that apply. ${ }^{246}$ In the overall context of the Guidance, however, it is difficult to interpret this language as anything other than EPA's intent to focus on state laws and regulations alone. ${ }^{247}$ As such, relying on state law to define the scope of federal civil rights protection would amount to an abdication of EPA's federal responsibilities under Title VI. After all, such reliance would leave decisions about what impacts to consider within the discretion and the manipulation of the states. At its worst, it could result in narrowly defined en-

State, and Local Environmental Justice Programs 26-29 (1999), available at http:// www.epa.gov/ocrpagel/t6faca.htm (last visited Jan. 14, 2002); Draft Title VI Recipient and Revised Investigation Guidance, supra note 17, at 39,674-75 nn.105-06 ("Under the Givil Rights Act of 1964, EPA is charged with assuring compliance with Title VI and cannot delegate its responsibility to enforce Title VI to its recipients. Therefore, [EPA] cannot grant a recipient's request that EPA defer to a recipient's own assessment that it has not violated Title VI or EPA's regulations or that EPA rely on an assertion that a Title VI program has been followed.").

241 Draft Title VI Recipient and Revised Investigation Guidance, supra note 17 at $39,674-76$.

242 See id.

243 Id. at 39,678 .

244 See id.

245 See id.

246 See id.

247 See Draft Title VI Recipient and Revised Investigation Guidance, supra note 17 at 39,678 . 
vironmental decision-making criteria that effectively foreclose any successful assertion of disparate impact claims. ${ }^{248}$

\section{B. The Role of Quantifiable and Intangible Values in Regulation}

The inadequate consideration of incommensurables within environmental regulation has presented another obstacle to better incorporation of environmental justice concerns.

\section{Incommensurables in Civil Rights Law}

Intangibles and incommensurable values have broadly pervaded civil rights law. That is in part because of the broad role that courts have played in this area of the law. Their institutional limitations, including limited resources and narrow jurisdiction, have made them dependent on litigants to bring matters before them and to present the issues. ${ }^{249}$ As institutions operating in a context of ideals, simplified facts, and limited issues, their decision-making processes have focused on principles and the analysis of rights. ${ }^{250}$ Naturally, these institutional limitations have made courts less able to deal with the quantifiable values and considerations of scientific and technical issues than with incommensurables. ${ }^{251}$ Their competence in rights, principles, and other incommensurables seems almost useless in an area where empirical study is crucial, and the decisions themselves are practically judged by the quality of the outcomes as opposed to the quality of the process. 252 While courts may be empowered to appoint scientific experts to evaluate technical issues, ${ }^{253}$ that is a poor substitute for the

248 Arguably, under such a deferential view of state authority, state law could simply specify that environmental decisions cannot consider disparate impacts, whether racial or otherwise. This would of course run directly counter to the broad purposes and reach of Title VI, and it seems unlikely that states could insulate themselves from the reach of Title VI in such a fashion. It also points out, however, how untenable such a view of Title VI is. See Letter from Lawyers' Committee for Civil Rights Under Law to Carol Browner, Administrator, EPA 18-25 (Aug. 28, 2000) (on file with author), available at http://www.epa.gov/ civilrights/docs/t6com2000_060.pdf (last visited Jan. 14, 2002) [hereinafter Letter from Lawyers' Committee]; see, e.g., Gardner v. Alabama, 385 F.2d 804, 815 (1967) (requiring active efforts by states to ensure non-discrimination within their programs).

249 See LANDIS, supra note 200 , at 38.

250 See generally id. at 30-40.

251 See id. at 30-31.

252 See generally id.

25s See FED. R. Evid. 706. 
institutionalized technical expertise and resources of administrative agencies. ${ }^{254}$

Yet, there are also considerations specific to civil rights law itself. For instance, the blameworthiness that anti-discrimination law assigns is not dependent on any particular harmful outcome. ${ }^{255}$ Rather, it is the act itself that is morally tainted by the discriminatory motive and that is therefore wrong. ${ }^{256}$ In contrast, actions that have discriminatory effects, but are not the direct result of discriminatory motives, generally do not violate anti-discrimination principles. ${ }^{257}$

That is not to say that quantifiable economic impacts and other consequences of discrimination are of no consequence for racial minorities. After all, economic, educational, housing, and other opportunities arguably affect vital and basic interests in survival and shelter, which discrimination significantly impairs. ${ }^{258}$ It would be difficult to argue that these concerns were not also important to civil rights laws. ${ }^{259}$ Nevertheless, the primary focus on equality and other incommensurables has pervaded civil rights law at least since Brown v. Board of Education..$^{260}$

\section{Scientific and Economic Analysis in Environmental Regulation}

In contrast, the federal environmental regulatory framework has relied heavily on quantifiable considerations in agency decisionmaking. ${ }^{261}$ Technical/scientific standards ensure that pollution emissions are limited ${ }^{262}$ or that the harmful environmental effects of

254 See supra notes 202-218 and accompanying text.

255 See Arlington Heights v. Metro. Hous. Dev. Corp., 429 U.S. 252, 264-71 (1977); Washington v. Davis, 426 U.S. 229, 240-41 (1976).

256 See Arlington Heights, 429 U.S. at 264-71; Davis, 426 U.S. at 240-41.

${ }^{257}$ Disparate impact provisions, such as those under Title VII and Title VI, have sought to change such premises. See 42 U.S.C. $\$ \$ 2000 d-2000 d-7$ (2000); see also supra notes 114 123, 203 and accompanying text.

258 Heart of Atlanta Motel, Inc. v. United States, 379 U.S. 241, 252-53 (1964); id. at 291-93 (Goldberg, J., concurring).

${ }^{259}$ See id.

260347 U.S. 483, 493, 495 (1954) (“[T] he physical facilities and other 'tangible' factors may be equal, ... [but s] eparate educational facilities are inherently unequal."); Heart of Atlanta Motel, Inc., 379 U.S. at 291 (Goldberg, J., concurring) ("[P] rimary purpose ... [of civil rights law] is the vindication of human dignity and not mere economics.").

261 See, e.g., Clean Water Act $\$ 302$ (d), 33 U.S.C. \$ 1312(d) (2000); Clean Air Act $\S \S 108(a)(2), 112$ (d) (2000), 42 U.S.C. $\$ \S 7408$ (a) (2), 7412(d) (2000).

262 See, e.g., Clean Water Act $\S 302$ (d), 33 U.S.C. $\$ 1312(d)$; Clean Air Act $\S \S 108(a)(2)$, 112(d), 42 U.S.C. $\$ \S 7408$ (a) (2), $7412(d)$. 
chemicals such as pesticides stay within acceptable limits. ${ }^{263}$ More importantly, scientific and technical analysis have allowed the environmental regulatory system to adapt to changing scientific knowledge and understanding of the environment as well as to anticipate unknown risks and harms. ${ }^{264}$

At the same time, the persuasive influence of market failure explanations for environmental problems and the utilitarian focus on economic efficiency considerations have compounded the influence of quantifiable considerations.decision-making ${ }^{265}$ These economic concerns have shaped modern environmental statutes through a diversity of regulatory mechanisms, with approaches ranging from the use of market mechanisms, ${ }^{266}$ to command-and-control regulations, ${ }^{267}$ to environmental quality standards. ${ }^{268}$ The result has been that no particular value can be identified as uniformly pervading environmental regulation other than the importance of compliance and environmental improvement itself. The main question is, "How well does a regulatory approach protect the environment and at what cost?" Little is vested in either the particular regulation itself or the process of arriving at the desired goal. ${ }^{269}$

263 Federal Insecticide, Fungicide, and Rodenticide Act $\$ \S 2(b b), 3(c)(5), 7$ U.S.C. $\S \S 136(\mathrm{bb}), 136 \mathrm{a}(\mathrm{c})(5)(2000)$.

264 See Percival, supra note 228, at 1161 . The trend has been toward more comprehensive approaches to environmental protection. See, e.g., RoDGERS, supra note 229, at 54-58, 59-60; Lakshman Guruswamy, Integrating Thoughtways: Re-Opening of the Environmental Mind?, 1989 Wis. L. REv. 463, 508 (1989); see generally J.B. Ruhl, Thinking of Environmental Law as a Complex Adaptive System: How to Clean Up the Environment by Making a Mess of Environmental Law, 34 Hous. L. REv. 933 (1997). Of course, these regulatory systems designed to protect the water and the air are not perfect. In fact, a significant amount of pollutants escapes the current regulatory scheme. For instance, non-point pollution sources, such as agricultural run-off, are not covered by existing Clean Water Act regulations.

In the natural resource protection context, such imperfect regulation has evidenced itself through the move toward habitat conservation in protecting endangered species and other biological resources. See generally U.S. Fish and WildLife SERv. \& National Marine Fisheries Serv., Habitat Conservation Planning Handbook (1996). For a critical review of the government's approach toward habitat conservation, see generally Patrick Parenteau, Rearranging the Deck Chairs: Endangered Species Act Reforms in an Era of Mass Extinction, 22 WM. \& Mary Envtr. L. \& Pol'y Rev. 227 (1998).

265 See, e.g., Mark Sagoff, The Principles of Federal Pollution Control Law, 71 MinN. L. REv. 19, 55-90 (1986).

266 See, e.g., Clean Water Act $\$ 309$ (d), (g) (3), 33 U.S.C. $\$ 1319$ (d), (g) (3) (2000) (recovering economic benefit of violation); Clean Air Act Amendments of 1990, Title IV, 42 U.S.C. $\$ 765 \ln (2000)$.

${ }_{267}$ See, e.g., 33 U.S.C. $\$ \S 1311$ (technology standard), 1342; 42 U.S.C. $\$ \S 7661$ a , 7475.

268 See, e.g., 33 U.S.C. $\$ 1313 ; 42$ U.S.C. $\$ 7470$.

269 See generally Sagoff, supra note 265. There have, of course, been critics arguing that the environmental regulatory system is not paying enough attention to economic 
In a sense, reliance on science and economics has thus facilitated environmental protection and regulation not only by making it easier to prove the need for regulatory action, but also by providing a tool to limit the necessary remedial action so that it does not impose too great a burden on industrial development and other economic activities.

\section{The Failing of Technical Approaches for Environmental Justice}

Even though the reliance on quantifiable data for decisionmaking has improved environmental regulation in many respects, it has also had a subversive influence. Because quantifiables tend to be impressive easy to grasp and identify, they overpower and dominate the unquantifiable aspects of the regulatory decision-making process. They obscure the role of the unknown and the uncertain, ${ }^{270}$ as well as

efficiency. See generally Bruce A. Ackerman \& Richard B. Stewart, Reforming Environmental Law, 37 STAN. L. Rev. 1333 (1985). Others, however, have criticized environmental policy as relying too heavily on utilitarian considerations. See, e.g., Sagoff, supra note 181, at 141018.

In contrast, European approaches to environmental degradation have largely been guided by a Kantian perspective that sees the "solution to pollution [as] moral conduct (cease pollution) rather than ... as a market failure to be corrected by market pragmatism." Jonathan Baert Wiener, Center for the Study of American Business, Policy Study Number 143, Designing Global Climate Policy: Efficient Markets Versus Political Markets 34 (1997). Commentators have noted the contribution of the environmental regulatory process toward the development of domestic civic republican virtue by promoting the articulation and building of public values. See, e.g., Jonathan Poisner, $A$ Civic Republican Perspective on the National Environmental Policy Act's Process for Citizen Participation, 26 EnvTL. L. 53, 55 (1996) (discussing whether NEPA encourages the "deliberative ideal"); Zygmunt J.B. Plater, Environmental Law as a Mirror of the Future: Civic Values Confronting Market Force Dynamics in a Time of Counter-Revolution, 23 B.C. ENvTL. AFF. L. Rev. 733, 734-42 (1996).

270 Especially with regard to scientific considerations, there are always new questions. We will likely never know all there is to know and be able to quantify things with the exactitude that critics calling for "sound science" would like ideally. See Daubert v. Merrel Dow Pharm., lnc., 509 U.S. 579, 589-90 (1993) ("It would be unreasonable to conclude that the subject of scientific testimony must be 'known' to a certainty; arguably there are no certainties in science."). That is, of course, not to deny the importance of scientific inquiry in addressing environmental problems. But scientific inquiry is an ongoing process that is never finished. $I d$.

Reliance on sound science has affected environmental regulatory thinking so much that the environmentalist's weapon in prompting regulatory action-scientific proof of a link between a pollutant or some human influence and an environmentally harmful effect-has been turned into an excuse to delay or avoid governmental intervention when clear proof of and quantifiable data about environmental or human health harms has not been found yet. The call for "sound science" has frequently become a means of avoiding what is currently considered politically unpopular—outright opposition to environmental regulation because of profit motives. Opposition of the biotechnology industry to regula- 
the importance of those values, such as ethical and distributional considerations, that cannot be measured. ${ }^{271}$ The overall outcome is one that is frequently warped and suspect, but nevertheless possesses the mantle of precision and objectivity. ${ }^{272}$

Yet, public policy is shaped as much by public values and ideals as by quantifiable science and utilitarian considerations. That has been especially true outside of the environmental context. ${ }^{273}$ Just because the government might make millions of dollars by euthanizing severely retarded individuals and harvesting their organs for sale to transplant patients does not make such actions societally or legally acceptable. The argument is not enhanced by the assertion that this method would be an economically efficient way to conserve scarce health care resources for more economically productive citizens while, at the same time, saving the lives of others. The idealism expressed in the Supreme Court's anti-discrimination jurisprudence and insistence on color-blindness provides ample illustration. ${ }^{274}$

This failing has been especially serious for environmental justice claims. ${ }^{275}$ Industrial plants or waste facilities might bring jobs, tax dollars, and much needed economic revitalization to depressed inner-city areas. ${ }^{276}$ Given the failure of economic analysis to capture many values relevant to community residents, it is not at all clear whether in any

tion of genetically engineered plants and foods, and the belittling of concerns about the potential human health and environmental risks of their widespread use because of a lack of specific scientific evidence arguably falls within this pattern. See Jack Kemp, Be Not Afraid, Use Genetics to Feed the World's Hungry; Agriculture: If We Don't Use Science to Farm More Intelligently, We Put People and Ecosystems at Risk, L.A. Times, Dec. 3, 1999, at B9; Marian Burros, Dual Role of Promoting Industry and Informing Puts U.S. Departments in a Bind, CHI. TRIB., July 5, 2000, at 3; see also Peter Huber, Gallileo's Revenge: Junk Science in the Cour'room 92-106, 148-69, 214-28 (1991).

${ }^{271}$ See, e.g., Howard Latin, Ideal Versus Real Regulatory Efficiency: Implementation of Uniform Standards and "Fine-tuning" Regulatory Reforms, 37 StaN. L. REv. 1267, 1328-32 (1985); Donald T. Hornstein, Reclaiming Environmental Law: A Normative Critique of Comparative Risk Analysis, 92 Colum. L. REv. 562, 616-33 (1992) (arguing that risk analysis is a poor substitute for necessary moral judgments about the environment).

272 See Laurence H. Tribe, Trial by Mathematics: Precision and Ritual in the Legal Process, 84 Harv. L. Rev. 1329, 1358-68 (1971).

273 See generally HuBER, supra note 270.

274 See, e.g., Adarand Constructors v. Pena, 515 U.S. 200, 217-31, 235-39 (1995) (finding that all racial classifications, even for those created for benign reasons, are subject to strict scrutiny).

273 See, e.g., R.I.S.E., Inc. v. Kay, 768 F. Supp. 1144, 1149 (E.D. Va. 1991).

${ }^{276}$ Some commentators have argued that such benefits do in fact accrue to the affected minority community or the poor. See, e.g., Marie A. Kirk \& Christine L. Wade, A Taxing Problem for Environmental Justice: The Tax Money from Hazardous Waste Facilities, Where It Goes, and What It Means, 16 STAN. ENvTL. L.J. 201, 202-03, 235-44 (1997). 
individual case such increased financial and economic benefits outweigh the increased health risks, odors, noise, traffic, and otherwise lower quality of life that usually accompany such facilities. 277 While issues of equality, autonomy, and community preservation frequently do not enter into environmental decision-making, they are nevertheless important concerns for environmental justice communities. Attempting to put price tags on such values is simply nonsensical; their inclusion in traditional cost-benefit analysis is not possible in a meaningful fashion. ${ }^{278}$

This difficulty indicates that EPA's decision to import more quantitative analysis, such as risk and exposure assessments, toxicityweighting, statistical analysis, pollutant concentrations, and ambient air quality standards, into its Title VI adverse disparate impact analysis may not necessarily help Title VI claimants. ${ }^{279}$ While statistical studies have been helpful in establishing a link between race and the siting of waste facilities, ${ }^{280}$ statistical evidence has not been a panacea for activists. ${ }^{281}$

277 See R.I.S.E., Inc., 768 F. Supp. at 1147 (raising concerns about noise, dust, odor, decline in property values, interference with religious and social activities, increased traffic and construction activities, and the blighting of a historic church and community).

278 Of course, environmental regulation has resorted to economic and scientific analysis only because, as a methodology for evaluating competing interests, it appears to be superior to other mechanisms. Its goal has been to allow us to make hard and difficult decisions in a more systematic and consistent fashion. Further, part of the task of effective environmental regulation is to continue to search for better ways to incorporate those factors that are currently not adequately considered in the analytical methodology.

Yet, many intangibles and incommensurables are simply not analyzable in a quantitative analytical framework-attempting to put uncertainty or equality into analytical quantities is meaningless in the end. The hard reality remains that environmental law has paid insufficient attention to values and considerations that have been of tremendous importance in just about every other area of law and public policy-intangible and incommensurable considerations that may not have a direct relevance to purely environmental concerns.

279 See Draft Title VI Recipient and Revised Investigation Guidance, supra note 17, at $39,676-82$. For example, whether there is a disparate impact for Title VI is determined by reference to statistical significance of "at least 2 to 3 standard deviations" of the disparity. Id. at 39,682 . Disparity findings are most likely to occur where "significant disparity is clearly evident in multiple measures of both risk or measure of adverse impact, and demographic characteristics." Id. But see Watson v. Fort Worth Bank \& Trust, 487 U.S. 977, 995 n.3 (1988); Hazelwood Sch. Dist. v. United States, 433 U.S. 299, 311 n.17 (1977) (refusing to apply specific standard deviation threshold to judge disparity); 29 C.F.R. 1607.4(D) (2001) (utilizing the $4 / 5$ standard for disparate employment discrimination).

280 See Kenneth J. Warren, Evidentiary Issues: Proving Intent and Effect and Defining the Affected Community, in The Law of Environmental Justice: Theories and Procedures to ADDRESS DisproporTionate Risks, supra note 34, at 397, 401-12.

281 See id. at 419-21. 
For example, just as general causation is only one important element of a toxic tort claim, ${ }^{282}$ statistical analysis is not the end of the judicial inquiry. ${ }^{283} \mathrm{~A}$ statistically significant correlation to race is only supporting evidence of discrimination. ${ }^{284}$ It generally does not in itself provide conclusive proof that discrimination occurred in any particular instance. ${ }^{285}$ As a result, statistical evidence is inadequate to make an environmental discrimination claim by itself. ${ }^{286}$

At the same time, statistical evidence can also prove too much. Even if there are no statistically significant disparities in the siting of hazardous waste facilities in racial minority and non-minority communities or other allocations of pollution or environmental burdens, that does not necessarily mean that discriminatory considerations did not enter into particular decisions. ${ }^{287}$

More disconcerting, statistical methods of proof provide a deceptive sense of definitiveness. ${ }^{288}$ In such analytical approaches, intangible and unquantifiable factors, such as aesthetics, odors, and other quality of life considerations, are "ignored or understated."289 The result is that "entire problems tend to be reduced to terms that misstate their underlying structure and ignore the 'global' features that give them their total character. ${ }^{290}$

EPA's Draft Revised Guidance fully bears out these concerns. ${ }^{291}$ There, it states that:

[D]ata may not be readily available for many types of impacts, or where available, may not be relevant to the appropriate geographical area. In some situations, the data may be 1999).

282 See, e.g., James A. Henderson, Jr. et al, The Torts Process 110-15 (5th ed.

${ }^{283}$ See Warren, supra note 280.

${ }^{284} \mathrm{Id}$.

288 But see Yick Wo v. Hopkins, 118 U.S. 356, 373-74 (1886) (finding an overwhelming statistical disparity as sufficient evidence to show discriminatory intent against Chinese laundry owners).

${ }^{286}$ In fact, even if disparate impact is shown in a claim under EPA's disparate impact regulations per Title VI of the Civil Rights Act, a defendant may still avert liability by providing a justification for such discriminatory impacts. See Draft Title VI Recipient and Revised Investigation Guidance, supra note 17, at 39,683.

287 See Vicki Been, Locally Undesirable Land Uses in Minority Neighborhoods: Disproportionate Siting or Market Dynamics?, 103 YALE L.J. 1383, 1392-1406 (1994).

${ }^{288}$ Laurence H. Tribe, Technology Assessment and the Fourth Discontinuity: The Limits of Instrumental Rationality, 46 S. CAL. L. REv. 617, 626 (1973).

289 Id. at 627.

290 Id. (emphasis omitted). 39,679 .

291 See Draft Title VI Recipient and Revised Investigation Guidance, supra note 17, at 
insufficient to perform an analysis. [EPA] expects to use available data in a hierarchical fashion depending on their completeness and reliability, placing greatest weight on the most reliable. ${ }^{292}$

Much of the data that might help Title VI complainants to prove their cases of disparate environmental burdens or overall adverse effects, isunlikely to be easily obtainable or even exist. The resulting reality will be EPA's primary reliance on quantitative information that it already possesses. 293

It is unlikely that a complaint process directed primarily at analyzing quantifiable factors will adequately and fairly judge the many intangible concerns, including aesthetic, dignity, and social impacts, complained of by environmental justice communities. ${ }^{294}$ After all, it is all too easy to think that “[i]f you can't count it, it doesn't exist." The accustomed dependence of agency staff on hard, quantifiable evidence and its illusory authoritative power will prevent a deeper understanding of discrimination and the concerns of environmental justice. ${ }^{296}$

292 Id. The expectation that EPA will focus on quantifiable considerations is clear in how EPA views impacts that will rise to a finding of non-compliance with EPA's Title VI regulations. Unless an impact "is significantly adverse, [it] is not expected" to lead to a finding of non-compliance. Id. at 39,680. The guidance's glossary also defines "significant" as an "observed value [that] is sufficiently large and meaningful to warrant some action." Id. at 39,684-88 app. A. (stating that a statistical significance is "an inference that there is a low probability that the observed difference in measured or estimated quantities is due to variability in the measurement technique, rather than due to an actual difference in the quantities themselves").

293 For example, in the Select Steel decision EPA based its finding of no disparate impact with regard to a state agency's failure to impose continuous emissions monitoring of dioxin because of the lack of applicable EPA performance specifications. See Select Steel Complaint Letter, supra note 118; see also Letter from Lawyers' Committee, supra note 248.

294 Tribe, supra note 272.

$295 \mathrm{Id}$. at 1361.

296 Of course, quantitative analysis, especially statistical analysis, has been used in other discrimination contexts, such as employment. See Griggs v. Duke Power Co. 401 U.S. 424, 426, 430 n.6 (1971). See generally Abigail Cooley Modjeska, Employment DiscriminaTION LAW $\$ 1.13$ (3d ed. 2000). Judicial evaluation of incommensurables, however, arguably results in much more careful and deliberate consideration of such concerns than administrative agency weighing. 


\section{The Limits of Regulation}

Finally, failure to resolve the conflicting understandings about the appropriate limits of regulation have also affected EPA's ability to address environmental justice issues.

\section{The Reach of Environmental Law and Civil Rights Law}

Because of the interconnection within the environment and the pervasiveness of pollution sources throughout society, from personal trash and auto exhaust to industrial emissions, pollution abatement and prevention have required comprehensive approaches to environmental regulation. ${ }^{297}$ The federal environmental statutes, with all of their imperfections, represent an important step in the implementation of this approach at a national level. ${ }^{298}$ Extensions of such efforts have prompted international programs, such as treaties protecting the ozone layer, ${ }^{299}$ and attempts to change public awareness and moral attitudes about pollution, consumption, and resource conservation. ${ }^{300}$ The administrative regulatory structure of environmental law has reinforced this comprehensive approach. ${ }^{301}$

In contrast, reliance by civil rights law on judicial adjudication as the primary means of regulation has emphasized much narrower lim-

297 See, e.g., Pollution Prevention Policy Statement, 54 Fed. Reg. 3845, 3847 (Jan. 26, 1989) ("EPA believes that the development of a comprehensive multi-media pollution prevention policy offers enormous promise for improvements in human health protection and environmental quality."); Pollution Prevention Strategy, 56 Fed. Reg. 7849 (Feb. 26, 1991); RoDGERs, supra note 229, at 59-60.

298 See, e.g., Clean Air Act, 42 U.S.C. $\$ 7401$ et seq (2000); RCRA, 42 U.S.C. \$ 1621 et seq (2000); see also City of Chicago v. Envtl. Def. Fund, 511 U.S. 328, 331 (1994) (RCRA instituted "a comprehensive environmental statute that einpowers EPA to regulate hazardous wastes from cradle to grave.").

299 See, e.g., Richard E. Benedick, Ozone Diplomacy: New Directions in Safeguarding the Planet 68-97 (1998); see also Vienna Convention for the Protection of the Ozone Layer, Mar. 22, 1985, 26 I.L.M. 1529 (entered into force Sept. 22, 1988); Montreal Protocol on Substances That Deplete the Ozone Layer, Sept. 16, 1987, 26 I.L.M. 1550 (entered into force Jan. 1, 1989).

300 See, e.g., National Environmental Education Act, 20 U.S.C. $\$ \S 5501-5510$ (2000) (establishing the office of environmental education in EPA and providing for environmental education grants, training, and education); see also EPCRA, 42 U.S.C. $\$ \S 11001,11044$ (a) (1986) (toxic release inventory); U.S. EPA, Office of Environmental Education, Explorers' Club, at http://www.epa.gov/kids (last visited Jan. 16, 2002).

${ }^{301}$ As John Landis described it, agencies are given "authority ... [and] an assemblage of rights normally exercisable by government as a whole" in order to fulfill their missions. LANDIS, supra note 200 , at 15 . Administrative agency authority is thus usually comprehensively delegated by the legislature. See id. 
its to the exercise of governmental power. ${ }^{302}$ Case-by-case development of the law, the counter-majoritarian nature of judicial power, as well as the reliance on principles and process considerations as the criteria for decision-making, rather than particular empirical evidence and outcomes, have created a tendency in the courts to narrowly confine their interventions. ${ }^{303}$ Concerns about maintaining the distinctive role of the courts vis-á-vis the legislature has also led them to exercise their authority sparingly. ${ }^{304}$

But there have also been limitations that have arisen out of the substance of civil rights law itself. ${ }^{305}$ Under equal protection doctrine, most civil rights statutes have been construed to reach only intentionally discriminatory actions, thus imposing significant limitations on the ability of courts to remedy the effects of discrimination. ${ }^{306}$

Another important limitation has been the focus of much civil rights law on discrimination connected to government actions or other aspects of the public sphere. ${ }^{307}$ This distinction is not just an artifact of the Fourteenth Amendment's state action language. ${ }^{308}$ It is also a significant feature of many congressionally enacted antidiscrimination statutes associated with varied non-governmental, private sector functions, such as employment, housing, or private pro-

302 See supra notes 74-75 and accompanying text.

s03 See Laurence H. Tribe, American Constitutional Law $\S \S 3-4,3-6,8-7,15-3$ (3d ed. 2001).

304 See CARDOZo, supra note 178, at 113-30.

305 See, e.g., Wygant v. Jackson Bd. of Educ., 476 U.S. 267, 276 (1986) ("Societal discrimination, without more, is too amorphous a basis for imposing a racially classified remedy.").

306 See Washington v. Davis, 426 U.S. 229, 242 (1976) (finding evidence of discriminatory impact insufficient for equal protection violation); Arlington Heights v. Metro. Hous. Dev. Corp., 429 U.S. 252, 265 (1977).

${ }^{307}$ Brown v. Bd. of Educ., 347 U.S. 483, 491-92, 494 (1954) (focusing on public education and the notion that "education is perhaps the most important function of state and local governments"). Even when the Court has found the reach of the equal protection clause to cover private institutions, including private schools, there has been a nexus to some form of public support, such as financial and other material support from the states. See Norwood v. Harrison, 413 U.S. 455, 464-66 (1973) (providing free textbooks to racially discriminating private schools is impermissible); Gilmore v. Montgomery, 417 U.S. 556, 566-69 (1973) (providing free use of public recreational facilities by discriminating private schools is impermissible); Bob Jones Univ. v. United States, 461 U.S. 574, 577-97 (1982) (finding that government's interest in preventing discriminatory practices by organizations seeking tax-exempt status prevailed over free exercise rights); see also Heart of Atlanta Motel v. United States, 379 U.S. 241, 268-69 (1964) (Black, J., concurring) (stating that public accommodation provisions of the Civil Rights Act of 1964, 42 U.S.C. $\$ 2000$ a (2000), prohibited discrimination by a motel even though they sought to compel "privately owned businesses to serve customers whom they did not want to serve").

308 See U.S. ConsT. amend. XIV. 
grams receiving federal funds. ${ }^{309}$ The implicit corollary to this focus has been that discrimination in a private setting is not a major governmental concern. ${ }^{310}$

The reach of civil rights law has also been significantly limited by the requirement that race-based remedies be permissible only to the extent that they are directly co-extensive with the proven violation..$^{311}$ Within the school desegregation cases, the extent of the legal viola-

309 See 42 U.S.C. $\$ \$ 2000$ a (public accommodations), 2000c (public education), 2000d (federally assisted programs), 2000e (employment), 3604 (housing). The description of some of these congressional acts, such as public accommodations, public education, or federally (and thus publicly) assisted programs, indicates clearly that, on their face, the protections apply only to activities in the public realm. Employment discrimination prohibitions apply to commercial acts that are commonly seen as dealing with the public. Id. $\S 2000 \mathrm{e}$. Even then, they apply only to employers having employees or more. Id. $\$ 2000 \mathrm{e}(\mathrm{b})$. Housing discrimination prohibitions, even though promulgated under the authority of the Thirteenth Amendment and thus able to reach private discrimination, do not apply, as a matter of congressional choice, to a "single-family house sold or rented by an owner" or "rooms or units in dwellings ... occupied ... by no more than four families $\ldots$ if the owner ... occupies one of [the] living quarters as his residence." Id. $\S 3603(\mathrm{~b})$. However, that exemption is lost if such racially discriminatory housing is commercially advertised. Id. $\S 3604$ (c); see also United States v. Hunter, 459 F.2d 205, 213-15 (4th Cir. 1972).

310 Of course, civil rights law is not exclusively concerned with public forms of discrimination. See, e.g., 42 U.S.C. $\S \S 1981$, 1982; see also The Civil Rights Cases, 109 U.S. 3, 23 (1883) (stating that "[u]nder the thirteenth amendment ... legislation, so far as necessary or proper to eradicate all forms and incidents of slavery and involuntary servitude, may be direct and primary, operating upon the acts of individuals, whether sanctioned by state legislation or not ...."). But see Runyon v. McCrary, 427 U.S. 160, 188-89 (1976) (Powell, J., concurring) (suggesting that "choices ... that ... are not part of a commercial relationship offered generally or widely, and that reflect the selectivity exercised by an individual entering into a personal relationship, certainly were never intended to be restricted by the 19th [C] entury Civil Rights Acts.").

Fundamentally, the public/private distinction in statutory anti-discrimination law simply respects the limitations that government should observe in reaching into the private affairs of its citizens. Within civil rights law, it recognizes that there are important values competing with anti-discrimination and equality for legal validation. The constitutional provisions that set out protections for free speech, religious free exercise, and other values make this clear. U.S. ConsT. amend. I. For more detailed discussions on the public/private distinction, see Robert H. Mnookin, The Public/Private Dichotomy: Political Disagreement and Academic Reputation, 130 U. PA. L. Rev. 1429 (1982), quoting Justice Marshall's concurrence in PruneYard Shopping Center v. Robbins, 447 U.S. 74, 93 (1980), and Morton J. Horwitz, The History of the Public/Private Distinction, 130 U. PA. L. REv. 1423 (1982). See also Symposium, The Public/Private Distinction, 130 U. PA. L. REv. 1289 (1982); Symposium, The State Action Doctrine, 10 Const. Comm. 309 (1993).

${ }^{311}$ For example, in school desegregation, remedies such as busing could only cover the students within a school district that had engaged in discriminatory actions. Larger patterns of segregation not directly caused by governmental action, but the result of associated "white flight," could not be redressed by the courts regardless of their exacerbating effects. Milliken v. Bradley, 418 U.S. 717, 801-02 (1974) (Marshall, J., dissenting). 
tion became the relevant measure for the courts' remedial authority. ${ }^{312}$ Antithetical to how environmental regulation approaches its problems, courts were not permitted to impose comprehensive solutions if doing so would exceed the scope of the proven prior constitutional violations. ${ }^{313}$ The result has been to drastically limit the ability of courts, and in the end also other parts of government, to redress the effects of past discrimination and on-going institutional or diffuse forms of discrimination. ${ }^{314}$

The fundamental difficulty with the limited reach of civil rights law is that it ignores the fact that discrimination, much like environmental degradation, is an aspect of life that is pervasive throughout society. ${ }^{315}$ It is the result of a web of interrelated public and private

312 Id. at $739-46$.

313 See id.; see also Wygant v. Jackson Bd. of Educ., 476 U.S. 267, 276 (1986) (finding that societal discrimination is insufficient for the government to remedy use of racial classifications); Swann v. Mecklenburg, 402 U.S. 1, 16 (1971) (stating that a constitutional violation is a relevant measure of the courts' remedial authority); Most lawyers would find this quite unremarkable, especially considering the primacy of adjudication in judicial decision-making. But that is precisely the heart of why civil rights regulation is so different from the actions of administrative agencies. See generally Alan David Freeman, Legitimizing Racial Discrimination Through Antidiscrimination Law: A Critical Review of Supreme Court Doctrine, 62 MIN. L. Rev. 1049 (1978) (arguing that Brown v. Board of Education, 347 U.S. 483 (1954), and the discrimination cases following having been characterized by a perpetrator perspective that has imposed important limits on government power to remedy discrimination); see also Sullivan, supra note 204, at 85-90.

314 City of Richmond v. J.A. Croson Co., 488 U.S. 469, 505 (1989) (stating that the Court has "never approved extrapolation of discrimination in one jurisdiction from the experience of another") (citing Milliken, 418 U.S. at 746). There is an astonishing undercurrent to this approach that can best be understood by considering what it would ask of government in other more technical/scientific areas of regulation. For example, applying such a decision-making approach to environmental regulation would require local governments or EPA to conduct experiments to document the applicability of the laws of physics and chemistry, and to demonstrate the ecological and public health consequences of pollution for each locale or jurisdiction in which it sought to regulate pollution.

315 Of course, my claim here is not that the federal environmental regulatory system is a perfectly all-encompassing regulatory scheme whereas civil rights law is unsatisfyingly piecemeal. As noted previously, the environmental laws are far from perfect. See discussion supra Part II.B. Various constitutional limitations, such as the Takings Clause, impose additional external constraints. And the constitutional limitations on anti-discrimination policies apply to all laws, including environmental protection laws. Yet, the practical impact of such limitations on environmental regulation has not had nearly the same disabling effect in restraining government intervention as it has had in the anti-discrimination context. Compare generally Lucas v. S.C. Coastal Comm'n, 505 U.S. 1003 (1992) with Milliken, 418 U.S. 717. 
causes in which private prejudice and private discrimination can be just as important as discrimination in its public manifestation. ${ }^{316}$

For instance, even though federal and state government actions have actively contributed to racially segregated housing patterns in the past, ${ }^{317}$ the importance of private actions such as "white flight" cannot be denied. ${ }^{318}$ Furthermore, consistently lower property values in racial minority neighborhoods compared to Caucasian neighborhoods have been attributed to individually discriminatory desires not to live in racial minority neighborhoods. ${ }^{319}$ Such patterns of private and public contributions to discrimination appear in many other areas, ranging from government contracting to employment to consumer transactions. ${ }^{320}$ Limiting civil rights protections to the public sphere thus leaves important sources and manifestations of discrimination unaddressed. ${ }^{321}$

316 See, e.g., Heart of Atlanta Motel v. United States, 379 U.S. 241, 252-53, 291-93 (1964) (Goldberg, J., concurring).

${ }^{317}$ See, e.g., Milliken, 418 U.S. at 728 n.7 (referencing lower court finding of Federal Housing Authority and Veterans Administration involvement in creating or maintaining racially segregated housing pattern); see also id. at $771 \mathrm{n} .5$ (White, J., dissenting) (noting that construction of schools in the heart of residentially segregated areas maximizes school segregation and perpetuates residential segregation).

318 Id.

319 See, e.g., Been, supra note 287, at 1388-89; Douglas S. Massey \& NanCy A. Denton, American Apartheid: Segregation and the Making of the Underclass 114 (1993).

320 See, e.g., Adarand Constructors v. Pena, 515 U.S. 200, 261 (1995) (Stevens, J., dissenting) (arguing that minorities face barriers to participation in government contracting because they do not have access to the pre-existing social relationships that are frequently crucial in obtaining subcontracts from prime contractors); see also id. at 271 (Ginsburg, J., dissenting) (citing various studies documenting continuing race discrimination); City of Richmond v. J.A. Croson Co., 488 U.S. 469, 531-33 (1989) (Marshall, J., dissenting); Ian Ayres, Fair Driving: Gender and Race Discrimination in Retail Car Negotiations, 104 HaRv. L. REv. 817 (1991); Ian Ayres \& Fredrick E. Vars, When Does Private Discrimination Justify Public Affirmative Action?, 98 Colum. L. Rev. 1577, 1592-96 (1998) (containing data about statistical disparities in private purchases from minority and non-minority businesses).

321 The Supreme Court has candidly acknowledged this state of affairs. The Civil Rights Cases, 109 U.S. 3, 17 (1883). In line with the limitations on the reach of government action regarding discrimination, however, the Court has held that general "[s] ocietal discrimination, without more, is too amorphous a basis for imposing a racially classified remedy" to provide relief for racial minorities. Wygant v. Jackson Bd. of Educ., 476 U.S. 267, 276 (1986). In fact, under Justice Scalia's view, "outside the context of school assignment, ... the continuing effects of prior discrimination [cannot] be equated with state maintenance of a discriminatory system," and thus does not justify government intervention. J.A. Croson Co., 488 U.S. at 525 (Scalia, J., concurring). But see J.A. Croson Co., 488 U.S. at 538 (Marshall, J., dissenting) ("The more government bestows its rewards on those persons or businesses that were positioned to thrive during a period of private racial discrimi- 


\section{The Limited Reach of EPA's Title VI Draft Revised Guidance}

EPA's disparate impact regulations under Title VI were expected by environmental justice activists to circumvent the problem of the limited reach of most civil rights law by focusing on discriminatory effects rather than discriminatory motivations. ${ }^{322}$ Applying a comprehensive regulatory approach to such issues should ultimately help environmental justice complainants vindicate their claims.

Yet, in evaluating disparate impact allegations under its Draft Revised Guidance, EPA will focus narrowly only on sources, stressors, ${ }^{323}$ and impacts that the fund recipient may consider under its decisionmaking authority, presumably state law. ${ }^{324}$ Even the consideration of such stressors and impacts will be largely limited to those that are quantifiable in nature and that can be causally linked or otherwise directly associated to the discriminatory permit action. ${ }^{325}$

Such a limited approach to discrimination issues may be in keeping with civil rights law doctrines that have sought to limit remedies to proven violations. ${ }^{326}$ Here, that would arguably be some violation of state law. ${ }^{327}$ According to such reasoning, only if the recipient could have considered certain impacts and stressors under its state law

nation, the tighter the deadhand grip of prior discrimination becomes on the present and future.").

There are, of course, a number of arguments as to why all forms of racial classification, whether benign or invidious, are inappropriate. These range from prophylactic concerns about the potential misuse of such classification to implement notions of prejudice and stereotype, the desire to strive directly for the long-term ideal of color-blindness, and the notion that racial classifications, as an abstract matter and regardless of their effects on particular groups, are evil in and of themselves. Each of these views depends on differing assumptions about what approaches are most effective in addressing discrimination and racial inequality and what the Constitution permits. Yet, they all share the characteristic that they find the continuing burdens of the present effects of past discrimination on racial minorities acceptable as a price to society, and they ignore the very different uses and impacts that racial classifications have had on racial minorities. In all of these views, history and the reality of inequality matter little compared to particular notions of causation and jurisdiction.

322 See Colopy, supra note 110, at 152-56; Light \& Rand, supra note 109, at 5 n.10.

${ }^{323} \mathrm{EPA}$ defines stressors as factors introduced into the environment that may adversely affect the health of humans, animals, or ecosystems, such as chemicals, noise, or odors. Draft Title VI Recipient and Revised Investigation Guidance, supra note 17, at 39,686.

${ }^{324}$ Id at 39,678 .

${ }^{325}$ Id. at $39,379-80$.

326 See supra notes 305-27 and accompanying text. Of course, the counter-argument would be that Title VI imposes anti-discrimination obligations independent of state law.

327 See Draft Title VI Recipient and Revised Investigation Guidance, supra note 17, at 39,678 . 
authority could there be a violation, and also a remedy, under EPA's Title VI regulations. ${ }^{328}$

The problem with such an approach is that Title VI is a civil rights statute that seeks to reach discrimination much more generally. ${ }^{329}$ After all, its goal is not only to ensure that racial minorities not "be subjected to discrimination under any program or activity receiving Federal financial assistance," however narrow one might construe the notion of discrimination, but also that they not "be excluded from participation in [or] be denied the benefits of" such programs. ${ }^{330} \mathrm{Ti}$ tle $\mathrm{VI}$ is thus broadly concerned with inequality in the distribution of benefits of federally funded programs. ${ }^{331}$

Even if a fund recipient's authority is broad enough to consider many concerns relevant to environmental justice activists, EPA's actual analysis is still likely to prove disappointing. As discussed above, most of the Guidance relies on quantitative analysis, such as risk and exposure assessments, toxicity-weighting, statistical analysis, pollutant concentrations, and ambient air quality standards to determine whether a disparate impact exists. ${ }^{332}$ Given EPA's intent to base its analysis mostly on complete and reliable data, ${ }^{333}$ most impacts and stressors for which little quantitative information is available would be given little weight. ${ }^{334}$ And since there are no benchmarks for community preservation, stigma, or even equality, considerations such as these will simply be ignored. ${ }^{335}$

Finally, and no less significantly, the Draft Revised Guidance seeks to analyze the discrimination claims by reducing them to their individual and discrete components-connecting particular impacts with particular causative factors so that a technical analysis can then quan-

${ }^{328}$ Id.

${ }^{329}$ Such reasoning would also misapply the remedies limitations to a wholly unrelated area of law. More aptly, this approach is a manifestation of its close cooperative partnerships with states and the deference that it tends to extend within environmental regulatory schemes. See supra notes 225-247, and accompanying text.

38042 U.S.C. $§ 2000 \mathrm{~d}(2000)$.

331 See also infra notes $441-480$ and accompanying text accompanying.

332 See supra notes 128-132 and accompanying text.

33s See Draft Title VI Recipient and Revised Investigation Guidance, supra note 17, at 39,679 .

394 EPA explicitly admits that the "evaluation would need to take into account considerations such as policies developed for single stressors or sources without explicit consideration of cumulative contributions and uncertainties in estimates. In some cases, the relevant environmental laws may not identify regulatory levels for the risks of the alleged human health impact or may not address them for Title VI purposes." Id. at 39,680.

33s See generally id. at $39,677-80$. 
titatively judge whether there is a disparity or inequality. Doing so might allow one to add up the individual disparities. Such reductionism, however, will not be able to capture the larger picture of inequality and discrimination that is made up of individually small and insignificant instances of unfairness and inequity. ${ }^{336}$

In the end, the analysis attempts to adopt a traditional model of common law tort causation within which particular effects can be directly linked to actors or actions that can then be described as the cause for these effects. This type of thinking is not surprising given that it characterizes much of civil rights law. ${ }^{337}$ But it is also the type of legal reasoning that has been abandoned by modern environmental regulation as unworkable in solving the problems of modern society.

Even though regulation of environmental harms was historically rooted in common law tort doctrines such as negligence, nuisance, and trespass, ${ }^{338}$ the failure of the common law in dealing with modern environmental degradation problems led Congress to enact the modern environmental regulatory framework. ${ }^{339}$ But if the common law system was unsuccessful in solving modern industrial pollution problems, then it should come as no surprise that the traditional common law methodologies embodied in the civil rights laws have failed the environmental justice movement in vindicating its concerns. Environmental justice activists' interests in race and equity may be "new"

${ }^{336}$ See Been, supra note 287 , at $1388-91$.

${ }^{337}$ It is arguably also an attempt, however disfavorable to environmental justice activists, to adopt a more traditional civil rights approach.

338 The common law roots can still be found, for instance, in the imminent hazard provision, section 7003, of RCRA, 42 U.S.C. $\$ 6973$, which "is essentially a codification of common law public nuisance remedies." S. REP. No. 96-172, pt. 1, at 5 (1980), reprinted in 1980 U.S.G.C.A.N. $\$ \S 5019,5023$.

${ }^{339}$ For example, the difficulties that toxic tort litigants have faced in linking their alleged harms to specific actors, substances, or acts are illustrative of these problems. Proof of a discrimination claim raises related indeterminacy problems of multiple causation factors and pre-existing conditions. For instance, in the hazardous waste facility siting context, environmental justice claimants have had to contend with non-discriminatory justifications for disparate siting and impacts, such as cost considerations or transportation access availability as well as the contributing impacts of pre-existing facilities. The toxic tort equivalent has been the attribution of harms to lifestyle choices or to environmental risks and harms other than those blamed on defendants at trial. Arguments that minority communities may not even be exposed to a facility's harmful pollutants are often times equivalent to arguments in toxic tort suits that a plaintiff has suffered no harm because he or she is asymptomatic. 
to environmental regulators; however, the obstacles encountered in the vindication of environmental justice claims are not. ${ }^{340}$

Thus, EPA's Title VI Guidance leaves regulators with a compartmentalized view of the causes and effects of the problem rather than an understanding that sees them as interconnected in nature and as manifestations of larger societal problems. ${ }^{341}$ For instance, the failure to identify the cause of discrimination with particularity leads to a finding that there is no redressable discrimination-in effect that there is no discrimination or inequality at all. ${ }^{342}$

In many respects, this recognition shows why EPA's Title VI Guidance, without even considering its specific content, is unlikely to succeed. Ultimately, the Guidance sets up a mechanism for EPA to respond to specific complaints of disparate impacts connected to a specific permit. ${ }^{343}$ Its understanding of the problem is derived through the lens of the permit criteria and limited by the specific permit. ${ }^{944}$ It is an approach that does not easily accommodate larger contexts of inequities and historical discrimination. ${ }^{345}$ Yet, perni-

340 To the extent that one can analogize the considerations that Steven Shavell has raised as being relevant to utilizing a harm management over liability approach, they provide some support for the application of the environmental regulatory model here as well. See generally Steven Shavell, Liability for Harm Versus Regulation of Safety, 13 J. LEG. STUd. 357 (1984). Thus, with regard to environmental justice claims, government agencies have a significant information advantage over any particular claimants, since government agencies have much easier access, and in fact, are provided with information about the distribution and locations of pollution facilities. Furthermore, once a facility has been permitted and built, it is unlikely because of sunk costs and reliance interests that an environmental justice claimant can be made whole or put into the same situation as prior to the facility's commencement of operations.

341 This understanding thus also rejects comprehensive approaches to redressing discrimination, which can include race-conscious measures such as affirmative action. Instead, government efforts must proceed in a piecemeal fashion. See, e.g., Wygant v. Jackson Bd. of Educ., 476 U.S. 267, 274-77 (1986) (rejecting role model rationale for preferring minority teacher over Caucasian teacher in layoffs); see also id. at 315 (Stevens, J., dissenting) (identifying reduction of prejudice as a benefit of white students being taught by minority teacher); Hopwood v. Texas, 78 F.3d 932, 950-51 (5th Cir. 1996); cf. City of Riclmond v. J.A. Croson Co., 488 U.S. 469, 497-98 (1989) (identifying as the reason for the insufficiency of the role model justification in Wygant the failure to provide a sufficiently close connection to demonstrated past discrimination, rather than denying the benefits of minority role models to children).

342 See Washington v. Davis, 426 U.S. 229, 242 (1976).

${ }^{343}$ See Draft Title VI Recipient and Revised Investigation Guidance, supra note 17, at $39,668-69$.

344 See id.

${ }^{345}$ See generally Yale Rabin, Expulsive Zoning: The Inequitable Legacy of Euclid, in ZonING and the American Dream 101 (Charles M. Haar \& Jerold S. Kayden eds., 1989) (showing that cities have zoned low-income communities of color for more intensive land uses); Arnold, supra note 50. 
ciously, it effectively allows discrimination and inequities to be blamed on such larger patterns of historical and societal discrimination while avoiding the tough actions that would need to be taken to solve them. ${ }^{346}$

\section{Finding Common Ground: The Substance of ENVIRONMENTAL JUSTICE}

The problem of the pervasiveness of the presence and effects of discrimination and its contribution to environmental inequities also suggests how EPA might make more effective use of Title VI to address environmental justice claims. Rather than focusing only on efforts to adjust the form of the regulatory mechanisms, a closer examination of the substance of the problems that EPA is charged with addressing would prove fruitful. Such a substantive approach to Title V's role in addressing discrimination has found only limited practical implementation in modern civil rights law. ${ }^{347}$ It is uniquely suited for EPA, however, in light of its role within the National Environmental Policy Act (NEPA) and its pervasive regulatory approaches. ${ }^{348}$

\section{A. The Rationality of Environmental Degradation and Discriminatory Behavior}

Considering the regulatory frameworks that govern environmental protection and civil rights provides important insight into how government officials and others having to work within these systems have understood these problems. Yet, precisely because of that perspective, this analysis also offers an incomplete understanding of the problems of discrimination and environmental degradation. ${ }^{349}$ These perspectives are shaped as much by the realities of the social problems they are charged with solving as they are by larger political and legal ideologies. ${ }^{350}$ At closer examination, both types of social problems share important similarities with regard to the rational impulses that result in discrimination and environmental degradation. ${ }^{351}$

\footnotetext{
346 Yang, supra note 24, at 24-28.

${ }^{347}$ Milliken v. Bradley, 418 U.S. 717, 758 (1974).

${ }^{348}$ See generally 42 U.S.C. $\$ 4332$ (2000).

349 See infra notes 367-374 and accompanying text.

350 See Yang, supra note 24, at 27-28.
}

351 Here, my use of the term "rational" is not equivalent to economically efficient. Rather, I use the term in its most general sense as including all actions that are engaged in because of specific reasons and contrast it to actions that are engaged in for no reason, for reasons that the actor realizes to be false, or for delusional reasons. For a discussion of the 


\section{The Market Failure Basis of Environmental Degradation}

Garrett Hardin's Tragedy of the Commons understands environmental degradation as a form of market failure-the result of rationally self-interested actions by individuals which ultimately cause harm to the community as a whole ${ }^{352}$ Because of the importance of rational behavior in contributing to environmental degradation, the generally accepted conclusion is that simple education or moral exhortation about the harm to the general community is insufficient to induce individuals or companies to change their polluting behavior. ${ }^{353}$ In the end, rational self-interest usually prevails. ${ }^{354}$

The prisoner's dilemma problem, of which the tragedy of the commons is one specific instance, demonstrates this easily. In this dilemma:

[T]wo prisoners ... are separately interrogated about a crime. The two were the only witnesses, so if they both refuse to testify, the worst that can happen to them is a one-year conviction for illegal possession of firearms. However, a clever prosecutor approaches each prisoner and offers him a proposition: "If you confess and testify against your partner, he'll get life but you'll go free; the only hitch is that if you both confess, you'll both get a sentence of 6 years for armed robbery. I should tell you that I'm offering the same deal to your partner." 355

Assuming that the game is played only a single time, and assuming further that the prisoners are rational and motivated only by selfinterest, they will both confess-and get six years in jail, rather than keep quiet and get off with only a year. The paradox, of course, is that by pursuing their individual self-interest, the prisoners behave in a

various conceptions of rational actions, see Russell B. Korobkin \& Thomas S. Ulen, Law and Behavioral Science: Removing the Rationality Assumption from Law and Economics, 88 CALIF. L. REv. 1051, 1060-66 (2000). For a general critique of economic approaches to law, see Arthur Allen Leff, Economic Analysis of Law: Some Realism About Nominalism, 60 VA. L. REv. 451 (1974).

352 Hardin, supra note 57.

35s Id. There have also been significant criticisms of the tragedy of the commons understanding of environmental degradation. See R.H. Coase, The Problem of Social Cost, 3 J.L. \& Econ. 1 (1960). See generally Carol Rose, The Comedy of the Commons: Custom, Commerce, and Inherently Public Property, 53 U. CHI. L. REv. 711 (1986).

334 Hardin, supra note 57.

${ }^{335}$ E. Donald Elliott et al., Towward a Theory of Statutory Evolution: The Federalization of Environmental Law, 1 J.L. EcoN. \& ORG. 313, 324 (1985). 
way that is contrary to their shared collective interest in shorter sentences. ${ }^{356}$

The prisoner's dilemma has been used to illustrate many varying points about the obstacles to collective action. ${ }^{357}$ Here, it illustrates not only the power of self-interest in defeating any sense of moral obligation to advance the common good, but also the ability of freeriders to undermine or even destroy the benefits of communally conscious actions. ${ }^{358}$ After all, as it is within the nature of the prisoner's dilemma and the tragedy of the commons, there are no tools available by which the co-prisoners can stop each other from choosing the selfish course of action, even if that results in a less than optimal outcome for the community as a whole. ${ }^{359}$

As a result, government intervention into environmental problems has come in the form of coercive regulatory action. ${ }^{360}$ While education regarding harms of pollution and environmental degradation can be helpful and important in the same way that it can help the prisoners understand the benefits of cooperation in order to appreciate the full scope of the dilemma, such measures cannot by themselves solve the collective action problem presented. ${ }^{361}$ To achieve the optimum beneficial outcome for both prisoners, coercive action designed to ensure that neither prisoner confesses is necessary. In the environmental context, this has meant that government regulations must impose coercive restrictions on activities that degrade the environment. ${ }^{362}$

2. The Conventional Understanding of Discrimination as Irrational Behavior

Within civil rights scholarship, a similar understanding about the underlying causes of discrimination has become increasingly ac-

356 Id.; see also Rodgers, supra note 229, at 39-42; see generally ROBERT AXELrod, The Evolution of Cooperation (1984); Mancur Olson, The Logic of Collective Action: Public Goods and The Theory of Groups (1965).

357 Elliott et al., supra note 355, at 324; see also RoDgers, supra note 229, at 39-42; see generally Robert AXelrod, The Evolution of Cooperation (1984); Mancur Olson, The Logic of Collective Action: Public Goods and the Theory of Groups (1965).

958 See Hardin, supra note 57.

359 See AXELRod, supra note 356, at 9.

360 See, e.g., 20 U.S.C. $\S 5509$ (2000).

361 See AXELRod, supra note 356, at 10-11.

362 See, e.g., 42 U.S.C. $\$ 6929$ (2000) (containing federal enforcement provisions of RCRA). 
cepted. ${ }^{363}$ The conventional wisdom about discrimination, however, has been quite different. ${ }^{364}$

Since the earlier part of the twentieth century, the conventional wisdom has been that "racism ... is irrational," 365 because it is based on well-known and persistent errors of judgment about others based on racial group membership. ${ }^{366}$ The negative attributes ascribed by racist beliefs to a racial group are either simply false or constitute unjustifiably over-broad generalizations. ${ }^{367}$ Yet, these notions have exerted a peculiar power. ${ }^{368}$ Unlike factual misconceptions or generalizations, beliefs rooted in prejudice and racism "are not reversible when exposed to new knowledge. ${ }^{n 69}$ They persist in spite of facts to the contrary. ${ }^{370}$

Some, such as Gary Becker, have sought to provide explanations by locating discrimination not necessarily in irrational actions based on faulty reasoning but rather in pre-rational thoughts. ${ }^{371}$ Thus, discrimination is not the result of a "mistaken" belief about a particular racial minority group but rather because the individual has a "taste for

363 See infra notes $395-407$ and accompanying text.

364 Gordon W. All.port, The Nature of Prejudice 3-9 (1954).

365 Edmonson v. Leesville Concrete Co., Inc., 500 U.S. 614, 643 (1991) (O'Connor, J., dissenting) (stating that "[r]acism is a terrible thing. It is irrational, destructive, and mean.").

366 All.port, supra note 364, at 3-9. Prior to the 20th century, beliefs in the superiority of the "white race" over others was accepted by many as true. Linda Hamilton Krieger, The Content of Our Categories: A Cognitive Bias Approach to Discrimination and Equal Employment Opportunity, 47 Stan. L. Rev. 1161,1174 n.39 (1995); see also GUNNAR Myrdal, AN AMERcan Dilemma: The Negro Problem and Modern Democracy 83-97 (1962). Since then, the use of race and skin color as a criterion for legitimate distinctions between individuals with regard to their character, merit, intelligence, and virtually all other personal characteristics has been largely discredited. See generally Stephen Jay Gould, The Mismeasure of MaN (1996) (discussing how racial prejudices have led to false scientific claims about racial differences and the superiority of Caucasians). Nevertheless, because of their attractiveness in explaining social inequality, such views resurface periodically. See, e.g., RICHARD J. Herrnstein \& Charles Murray, The Bell Curve: Intelligence and Glass Structure in American Life (1994). But see Stephen Jay Gould, Curveball, The New Yorker, Nov. 28, 1994 , at 139.

${ }^{367} \mathrm{Id}$.

368 All.PORT, supra note 364, at 17-27.

369 Id. at 9 (emphasis removed). Such "antipathy [is] based upon a faulty and inflexible generalization" about racial distinctions and the inferiority of non-Caucasians. Id.

370 MYrdal, supra note 366 , at 100 . This has held especially true with regard to racial beliefs about African-Americans. "In this magical sphere ..., the Negro is inferior, totally independent of rational proofs or disproofs [;] he is inferior in a deep and mystical sense." Id. 1971).

371 See generally Gary S. Becker, The Economics of Discrimination 16-17 (2d ed. 
discrimination." 372 According to Becker's seminal 1957 treatment of this issue, discrimination can be a response to an inherent desire by an individual to avoid associating with members of particular racial minority groups. ${ }^{373}$ Such desires have the status of inherent likes and dislikes or values, similar to individual preferences for vanilla ice cream over chocolate ice cream. ${ }^{374}$ Accordingly, prejudice and discrimination are only symptoms and implementation mechanisms of desires and values that cannot be explained or justified by, and in fact precede, rational thought or logic. ${ }^{375}$

To be sure, even this kind of reliance on race in governmental decision-making is considered '“utterly irrational,' and repugnant to the principles of a free and democratic society" because it "rests on the false premise that differences in race, or in the color of a person's skin, reflect real differences that are relevant to a person's right to share in the blessings of a free society." considered an illegitimate and inappropriate criterion for distributing the benefits of membership in our society. ${ }^{377}$

The conventional view of discrimination thus understands it as behavior that is quite different from the type of behavior that results in environmental degradation problems. ${ }^{378}$ Rather than being an unintended byproduct of individual pursuit of self-interest and personal gain, as in the tragedy of the commons model ${ }^{379}$ and the prisoner's dilemma, discrimination and racism are instead seen as either ends in themselves, as a manifestation of a fundamental dislike of members of other racial groups, or as "mistakes"-incorrect evaluations and

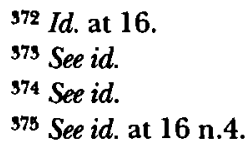

${ }^{376}$ Wygant v. Jackson Bd. of Educ., 476 U.S. 267, 316 (1986) (Stevens, J., dissenting) (quoting Cleburne v. Cleburne Living Center, 473 U.S. 432, 452 (1985)); see also id. at 31314 (Stevens, J., dissenting) (stating that the consideration of race in decisions regarding jury service, use of public services, marriage, and child custody is "utterly irrational' because it is completely unrelated to any valid public purpose"); AllPORT, supra note 364, at 3-28 (discussing the unwarranted categorizations and beliefs that make up prejudice); MYRDAL, supra note 366, at 97-101; Lawrence, supra note 75, at 331-39 (discussing psychoanalytic and cognitive explanations for the irrationality of prejudice).

${ }^{377}$ City of Richmond v. Croson, 488 U.S. 489, 526-28 (1989) (Scalia, J., concurring).

${ }^{378}$ See, e.g., James A. Henderson, Jr. \& Richard N. Pearson, Implementing Federal Environmental Policies: The Limits of Aspirational Commands, 78 CoLuM. L. REv. 1429, 1433 n.16 (1978) (stating that "civil rights matters do not ordinarily involve "the tragedy of the commons,' which operates to lead persons to maximize their own short run self-interest at the expense of their long run welfare").

${ }^{379}$ HARDIN, supra note 57. 
judgments about racial minorities. ${ }^{980}$ Discrimination, unlike environmental degradation, is thus an unnatural phenomenon and the result of the breakdown of ordinary and legitimate individual decisionmaking processes. ${ }^{981}$

This understanding indicates that education about the "mistake" of racism and prejudice will not be sufficient as a remedy to overcome discrimination. ${ }^{382}$ Rather, because of its roots in pre-rational preferences against members of other racial groups, such preferences can only be changed or eliminated by deeper personal changes in values and attitudes toward other races-processes that depend as much and maybe even more on personal relationships and interactions than on governmental coercion and regulation. The power of this understanding of discrimination is demonstrated by the significant success that integration and diversity efforts in public education, the work place, and housing have had in changing people's attitudes and behavior toward racial minorities.

\section{The Rationality of Discriminatory Behavior}

Yet, in spite of the widespread acceptance of this understanding, ${ }^{383}$ it is too simplistic. Explaining racism and prejudice only as the result of pre-rational affinities and irrational judgments forecloses any further analytical inquiries into the nature of discrimination and its causes. After all, how can one analyze a phenomenon when it precedes (as pre-rational preference) ${ }^{384}$ or exists outside of (as a mistake) ${ }^{385}$ any analytical framework?

In the end, this conventional understanding of discrimination provides an incomplete view of the problem. It ignores the concept that discrimination is a phenomenon, like environmental degradation, that is either an instrumental means for achieving other benefits and advantages or is the by-product of normal, self-interested, rational action. ${ }^{386}$

\footnotetext{
380 See BECKER, supra note 371, at 16-17; MYRDAL, supra note 366, at 100.

381 See Becker, supra note 371, at 16-17; MYRDAL, supra note 366, at 100.

382 MYrdal, supra note 366 , at 100.

${ }^{383}$ Wygant v. Jackson Bd. of Educ., 476 U.S. 267, 315 (1986) (Stevens, J. dissenting).

384 See BECKER, supra note 371, at 16-17.

${ }^{385}$ MYRDAL, supra note 366 , at 100.

386 Cass Sunstein, Three Civil Rights Fallacies, 79 CAL. L. REV. 751, 753 (1991). In recent years, increasing attention has also been focused on prejudice and discrimination as forms of cognitive errors-errors of association and categorization. See infra note 395.
} 
For instance, in third-party discrimination, ${ }^{387}$ a restaurant owner might engage in racial discrimination not because of his or her own prejudice, but rather in response to traditional market forces. ${ }^{388}$ Thus, in spite of having no "taste for discrimination" of his or her own, a business owner might exclude prospective racial minority employees or patrons from an establishment in order to cater to other patrons who do harbor racial prejudices. ${ }^{389}$ The result is the familiar exclusion of racial minorities from market transactions because of decreased commercial opportunities. ${ }^{390}$

A second form of racial discrimination that is the result of rational behavior arises out of the use of statistical evidence that appears to document differences between racial groups. ${ }^{391}$ Statistically based discrimination is premised on the notion that generalizations about racial minorities can serve as a predictor about particular members of minority groups. ${ }^{392}$ For example, statistical evidence about the model criminal suspect, including the suspects' most frequently recurring race (the racial profile), could arguably serve as a useful predictor by "lower[ing] the cost of obtaining and processing information, [and thus] . . . the overall cost of doing the business of policing. ${ }^{3993}$ There has, of course, been much criticism of racial profiling. ${ }^{394}$ But when time and resource availability impose real constraints on the ability to

387 See id. at 754 .

388 Id.

399 See Bell v. Maryland, 378 U.S. 226, 245 (1964) (Douglas, J., concurring) (stating that a restaurant may have refused service to African-Americans where "it' thought 'it' could make more money by running a segregated restaurant"); see also BECKER, supra note 371, at 75-77; Richard A. Epstein, The Case Against Employment Discrimination Law (1992) (arguing that employment discrimination can be a rational response by a firm to increase productivity by reducing inter-group conflicts); Sunstein, supra note 386 , at 75455.

390 BECKER, supra note 371, at 93-95. Housing segregation, lower home values, and "white flight" from neighborhoods that slowly become inhabited by racial minorities, especially African-Americans, is one of the most salient expressions of third party discrimination.

391 Sunstein, supra note 386 , at 755 .

992 Id. at 755-57 (discussing use of statistical information as predictor in employment decisions). In many respects, these racial profiles are little more than racial stereotypes, albeit generated through more sophisticated methods.

393 See, e.g., Developments in the Law-Race and the Criminal Process: III. Racial Discrimination on the Beat: Extending the Racial Critique to Police Conduct, 101 Harv. L. REv. 1494, 1503 (1988); Randall Kennedy, Suspect Policy, New Republuc, Sept. 13, 1999, at 30-31. See generally Randall Kennedy, Race, CRime and the LaW 136-67 (1997).

394 See generally Angela J. Davis, Race, Cops and Traffic Stops, 51 U. Miami L. Rev. 425 (1997); David A. Harris, The Stories, the Statistics, and the Law: Why "Driving While Black" Matters, 84 MinN. L. REv. 265 (1999). 
gather information, the perceived utility to any particular law enforcement officer of using a racial profile with regard to reducing decision-making time and costs might still make the use of such a generalization nevertheless rational and possibly even efficient. ${ }^{395}$

The third form of discrimination that is associated with rational behavior exists as a manifestation of ordinary cooperative behavior designed to advance the discriminator's interests. Like other forms of group cooperation, racism and prejudice can serve as a means for members of one racial group to cooperate with each other in order to create or preserve advantages over non-members. ${ }^{396}$ Racism can thus serve as a means of advantaging members of the more powerful racial group over others.

At their most concrete, prejudice and racism have created a system of racial privilege of Caucasians over racial minorities. Individuals participate in the maintenance of such a system because of the preferential employment or educational opportunities as well as other economic and social advantages that being Caucasian affords. ${ }^{397}$ Yet, this system need not provide only specific and concrete economic

${ }^{395} \ln$ fact, the deliberate use of generalizations about racial groups in decision-making is only the explicit use of cognitive categories that both Charles Lawrence and Linda Krieger have argued are important causes for discrimination. Lawrence, supra note 75; Krieger, supra note 366 . Categorization allows us to simplify the task of making sense of our daily experiences by filtering them through these categories. At the same time, categories also simplify decision-making by allowing missing information to be inferred, thus facilitating action under conditions of uncertainty or imperfect information. Lawrence, supra note 75, at 324 (stating that "categorization" is a process by which "humans ... make sense of experience. Too many events occur daily for us to deal successfully with each one on an individual basis; we must categorize in order to cope."); see also Krieger, supra note 366, at 1188-90.

Yet, while categorization is a fact of life, it is not an entirely self-contained and independent process, nor does it proceed in an objective and exact fashion. Category formation can be influenced by outside factors, including the stereotypes and categories of others as well as those of prevailing culture and society. Krieger, supra note 366, at 1195-98. Likewise, category formation can be affected by "illusory correlations'- the subjective perception of a strong correlation that objectively does not exist." Id. at 1195 . In the race context, these categorization defects explain how racial stereotypes are created and how they are perpetuated from generation to generation. It also explains how the underlying process, just like in the utilization of statistical information about race and crime, is essentially a rational process-it is an attempt, even if flawed, of rationally processing and using information in the face of real world constraints on available resources, time, and information itself. See Lawrence, supra note 75, at 336.

396 See generally Derrick Bell, Race, Racism, and American Law $63-68$ (1900); MIChael Omi \& Howard Winant, Racial Formation in the United States: from the 1960s To THE 1990s (2d ed. 1994).

397 See generally Cheryl I. Harris, Whiteness as Property, 106 Harv. L. Rev. 1709, 1762 (1993). 
benefits. For example, even individuals of poor Caucasian working class backgrounds, who have received little in terms of concrete benefits from racism, are accorded, at a minimum, a higher social status than racial minorities. ${ }^{398}$ The resulting form of psychic satisfaction can be seen as contributing to an individual's sense of well-being or utility in the same sense that increased consumption of material goods can. ${ }^{399}$ W.E.B. Du Bois observed as early as the 1930 s that "the white group of laborers, while they received a low wage, were compensated in part by a sort of public and psychological wage" based on the lower social status of racial minorities. 400

Of course, the days of segregation and other forms of officially sanctioned discrimination aimed at preserving and perpetuating white supremacy are over. Equal opportunity and racial equality are now the idealized norms of the country. Yet, the truth of the recognition that members of the same group will tend to favor each other over non-group members remains valid. ${ }^{401}$ That recognition is not surprising to many who have argued for some time that self-interest has perpetuated racism and discrimination against racial minorities, albeit in different forms. ${ }^{402}$

\section{B. The Substantive Failing of EPA's Title V Regulatory Approach}

Considered in this fashion, then, discrimination is little different from the profit-maximizing behavior that leads to overuse of communal resources-it is, as Richard McAdams has characterized it, also a form of market failure. ${ }^{403}$ Prejudice and discrimination are analogous manifestations of efforts to achieve or preserve individual gain and advantage. ${ }^{404}$ Rather than an individual imposing harm on the entire community, the harm is imposed by members of the "in-group" on

398 See id. at 1791.

399 See Richard H. McAdams, Cooperation and Conflict: The Economics of Group Status Production and Race Discrimination, 108 HARv. L. REv. 1003, 1084 (1995).

400 W.E.B. Du Bois, Black Reconstruction in AMERica 700 (1935).

401 Psychological experiments have, in fact, provided confirmation that explicit delineations of group-membership, even ones based on random criteria, create a significant bias of group members against non-members regardless of fairness and maximum mutual gain considerations. Krieger, supra note 366, at 1192-93. Within the race context, this explains much of why discrimination arose in the first place, why it is so difficult to correct prejudicial beliefs with facts to the contrary, and why remedial approaches to discrimination have been so elusive. See generally Reva Siegel, Why Equal Protection No Longer Protects: The Evolving Forms of Status-Enforcing State Action, 49 STAN. L. REv. 1111 (1997).

402 E.g., Derrick Bell, ANd We Are Not Saved 26-50 (1987).

403 See McAdams, supra note 399, at 1074-78.

${ }^{404}$ See id. at 1066. 
those of the "out-group." 405 The ultimate motivation that gives rise to the harm is the same. ${ }^{406}$ Individuals overuse commons resources not because of evil intent or ill will, but rather because it is in their interest to do so-because the individual reaps the full benefit of his or her overuse of the commons, while only bearing a fraction of the burden. ${ }^{407}$ Similarly, discrimination can be seen as resulting from underlying economic and personal incentive structures that promote racism and prejudice. ${ }^{408}$

There is no need for an individual to harbor specific ill will or racial hatred toward racial minorities in order to engage in actions or contribute to the perpetuation of structures that discriminate against racial minorities. Pursuit of individual self-interest is sufficient motivation. Nor is it necessary that an individual consciously seeks to disadvantage racial minorities specifically for personal gain. ${ }^{409}$ Usually, the perpetuation of existing institutions and structures that preserve the unequal status quo-advantaging the majority at the expense of minorities-is all that is needed. ${ }^{\mathbf{1 0}}$

Certainly, other explanations for discrimination and racial disparities exist. ${ }^{411}$ But to the extent that discrimination finds its roots in rational behavior, narrowly limited governmental intervention will be

${ }^{405} I d$. at 1014-16.

406 See id.

${ }^{407}$ Of course, unregulated access does not only suggest lack of legal regulation, but also suggests a lack of customary and other informal communal regulations, since such informal regulations can ameliorate the tragedy of the commons. See Carol Rose, The Comedy of the Commons: Custom, Commerce, and Inherently Public Property, 53 U. CHI. L. REv. 711, 742 (1986).

${ }^{408}$ See McAdams, supra note 399, at 1029-33.

${ }^{409}$ The perpetuation of racial privileges and discrimination can usually be rationalized through racial stereotypes and race-neutral norms, including institutional processes that are historically biased against racial minorities. See McAdams, supra note 399, at 1072-74; see generally Lopez, supra note 74. For example, the call for color-blindness and claims of reverse discrimination arguably justify opposition to race-based remedial measures for past discrimination, such as affirmation action.

${ }^{410}$ Unlike environmental degradation, discrimination must be pursued in cooperation with other members of the same racial group in order to successfully achieve its purpose. By definition, the benefits of discrimination are not within the capacity of individuals to achieve by themselves, because they depend inherently on interactions and relationships with others-the preferential treatment or higher social status that is accorded to the discriminator by others.

In fact, as McAdams has pointed out, social exclusion mechanisms, such as segregation, serve important purposes in maintaining group cohesion and ameliorating groupinternal prisoner dilemma-type problems that the occasional economic benefit of defection (i.e., the failure to discriminate) would present. See McAdams, supra note 399, at 1013-17.

411 See generally OMI \& WINANT, supra note 396, at 9-47. 
insufficient to remedy the effects of discrimination. Government actions and anti-discrimination protections that focus on individual attitudes and conduct about race alone and ignore the systemic and structural aspects of it will not lead to real solutions. If discrimination problems are not primarily problems of individual wrongdoing, but rather a larger social pathology that shares similarities with larger scale social problems, systematic and comprehensive government intervention is necessary. ${ }^{412}$

This conclusion hearkens back to what some scholars and others have emphasized for a long time-that the economic and structural underpinnings of racial inequality must be addressed just as much as individual attitudes in order to achieve true racial equality. Discrimination raises the same prisoner's dilemma issues that environmental degradation raises, except that in discrimination, the pay-off matrix for a discriminator provides the greatest benefit when he or she chooses discrimination. Education, good will, and changing individual attitudes alone are unable to end discrimination and social inequities. ${ }^{413}$ Just as environmental regulation has sought to reduce the economic incentives for environmental degradation, to effectively address discrimination, government may have to consider more explicitly the racial and distributional implications of decision-making and institutional structures, and take more race-conscious actions. ${ }^{414}$

The inability to fully understand this has been one of the main failings of EPA's current approach to environmental justice under the Title VI guidance. The Draft Revised Guidance, for example, requires an adverse environmental human health impact to be cognizable. ${ }^{415}$ As a practical matter, this is likely to mean that impacts must exceed established human health or environmental benchmark values provided by statutes, EPA regulations, or EPA policy. ${ }^{416}$ But the imposition of such absolute thresholds fails to recognize that much behavior and

412 See, e.g., id.; Krieger, supra note 366; Lawrence, supra note 75.

413 See Elliott et al., supra note 355, at 325 (raising the irrelevance of the prosecutor's role and acumen in the prisoner's dilemma). This understanding suggests that this form of discrimination is arguably not as morally reprehensible as others-after all, the discriminator does not harbor ill will per se toward the individual discriminated against. Instead, the harm results as a necessary by-product of the pursuit of self-interest. In contrast, one could also argue that the foreseeable and deliberate harm to racial minorities imposed for purposes of furthering one's self-interest is in fact more morally reprehensible than an unexplainable and innate racial hatred.

414 See e.g., Jerry Kang, Cyber-Race, 113 HaRv. L. REv. 1130 (2000).

415 See Draft Title VI Recipient and Revised Investigation Guidance, supra note 17, at $39,680-81$. 
action that impose a greater burden on minority and poor communities may not rise to such thresholds. By focusing the Draft Revised Guidance on only the most serious incidents, ${ }^{417}$ such objectionable behavior or activities will persist. Thus, rather than addressing the substance of the problem-the incentives leading to such behaviorit only addresses some of the symptoms.

A related problem arises with regard to the role of justification in the Draft Revised Guidance. ${ }^{418}$ While the Draft Revised Guidance indicates that "a goal that is legitimate, important, and integral to the recipient's institutional mission" justifies a discriminatory impact, "broader interests, such as economic development" may also justify discriminatory impact "if the benefits are delivered directly to the affected population." 419

The intent behind this interpretation of justification might have been noble, seeking to address the lack of economic development and job opportunities in many poor and minority communities. But it is likely to exacerbate the siting of undesirable facilities in such communities. After all, it immunizes environmental decisions against challenges under Title $\mathrm{VI}^{420}$ and, as a result, is likely to attract more undesirable facilities that cannot be sited anywhere else because of community opposition. Thus, when the environmental justice community will need the protections of Title VI the most, such protections may not be available because the economic development justification permits significantly adverse disparate impacts. ${ }^{421}$

Finally, the lack of specificity with regard to prohibited practices or considerations is also significant. ${ }^{422}$ The Draft Revised Guidance does suggest a variety of approaches to compliance, ranging from the comprehensive to the case-specific. ${ }^{423}$ Its primary focus, however, is on process issues, omitting more specific directions about the substantive obligations that the disparate impact regulations impose. ${ }^{424}$ For example, details with regard to prohibited practices, methods of enforcement, and suggested remedial actions are missing. ${ }^{425}$ Without

417 Id.

418 See id. at 39,683 .

419 Id.

420 See id.

421 Draft Title VI Recipient and Revised Investigation Guidance, supra note 17, at 39,683 .

422 See id. at 39,657 .

${ }^{423} \mathrm{Id}$.

424 Id.

${ }^{423}$ Letter from Lawyers' Committee, supra note 248, at 16-17. 
such detail, recipients will find it difficult to ensure that their actions are not influenced by corrupting discriminatory biases and to conform their conduct to the disparate impact prohibitions of Title VI.

In the end, EPA's ad hoc, case-by-case approach to resolving environmental justice complaints that the Title VI process sets out is inadequate for addressing the systemic and structural incentives that will continue to disadvantage racial minority and poor communities. Instead of reacting to problems raised by administrative complaints, EPA must proceed to understand the biases against environmental justice communities within its existing regulatory systems and proactively seek out regulatory solutions.

\section{Re-evaluating the Role of Title VI and EnVironmental Justice in ENVironmental Regulation}

Presently, no person would find acceptable the proposition that industrial pollution should occur unregulated, precisely because of the market failure problems described by Garrett Hardin's Tragedy of the Commons. ${ }^{426}$ Yet, that has not always been so, as the severe pollution problems of the 1950s and 60s and the lack of comprehensive controls on polluting activities during those times demonstrate. Likewise, public and open expressions of racial hatred and bigotry are socially unacceptable today. But in the 50 s and $60 \mathrm{~s}$, discrimination and segregation were part of the social fabric of communities, and change required the radical intervention of the federal government. ${ }^{427}$ In both contexts, change required people and businesses to fundamentally alter what was previously socially accepted behavior or common practice; but that did not stop reformers.

The same is true for environmental justice. What will be necessary is analogous structural reform. Yet, government has failed to take the problem sufficiently seriously as a structural and systemic matter. After all, any effective regulatory approach to environmental justice issues must not only address the tensions between the regulatory premises of civil rights law and environmental law; it must also focus on the real life incentives that lead to discrimination and distributional inequities in the same way that environmental regulation has focused on those real life incentives that lead to environmental degradation.

426 See HaRdin, supra note 57.

${ }^{427}$ See discussion supra Introduction. 
The application of such an understanding raises some important questions. In spite of this recognition, is there nevertheless an issue as to the competency of EPA in addressing discrimination issues? How can the majoritarian tendencies of a politically controlled administrative agency ${ }^{428}$ be tempered so as to provide effective minority protections? And what ought a constructive role for Title VI be within EPA's efforts to achieve environmental justice?

\section{A. Incorporating Civil Rights into Environmental Regulation: Assessing EPA's Institutional Competence}

Even if one can improve consideration of civil rights concerns through environmental regulatory processes, the ultimate question of competence remains. This conundrum is embodied in two closely related questions that appear to have made environmental regulators reluctant to address civil rights issues in their work: (1) Can environmental regulators adequately consider and implement civil rights values?; and (2) Should bureaucrats be involved in administering civil rights values and norms? ${ }^{429}$

As discussed above, many of the difficulties that EPA has encountered in addressing the civil rights and equity issues of environmental justice are embedded in the regulatory and institutional framework of environmental protection. ${ }^{430}$ Its decision-making processes and institutions seem unsuited to the types of judgments that must be made in the civil rights context. Given that an adequate understanding of and ability to deal with civil rights and discrimination concerns requires knowledge of the history of race relations, the sociology and psychology of inter-personal and institutional racial dynamics, and the counter-majoritarian protection needs of racial minorities, a cadre of technically and quantitatively inclined agency employees seems entirely unequipped to the task. Delicate social value and political judgments are arguably not within the competence of such a technical expert agency. In fact, the use of administrative and technical decisionmaking processes pre-supposes that a significant amount of consensus must exist about the methodology, such as race-blind versus raceconscious approaches, and values upon which a decision is to be

428 See discussion supra Part II.

429 These descriptive and normative questions are closely related because, arguably, if the competency exists, then it should be utilized. Conversely, if there is an appropriate role and mandate to address such issues, EPA should acquire the competency.

${ }^{430}$ See discussion supra Part I.C. 
based. Such a consensus largely does not exist, or at a minimum is fiercely contested in the civil rights context. Congress can supply some of these methodologies or values through specific statutory mandates. But it has largely not done so.

Federal agencies have been involved in the administration of civil rights laws. The roles of agencies such as the Equal Employment Opportunity Commission (EEOC) and the Departments of Education and Housing and Urban Development (HUD) in advancing civil rights demonstrate the functions that agencies can fulfill in this regard. ${ }^{431}$ However, unlike some other agencies, EPA also does not have an agency-specific congressional statutory mandate to consider civil rights and equity issues within its regulatory functions.

But even if it has an impoverished institutional experience in dealing with such issues, why can it not acquire such experience through its own efforts to address environmental justice issues? After all, agencies such as the EEOC and the Departments of Education and Housing and Urban Development were not created fully-formed with all of the experience necessary to fulfill their statutory missions. Like all agencies, their institutional expertise evolved with the acquisition of institutional experience over time.

As a practical matter, since EPA is a member of the family of federal agencies in the executive branch, it can draw on the civil rights knowledge and experiences of other agencies, including ones such as the Departments of Justice, Education, and Housing and Urban Development. For example, with regard to its formulation of the Title VI Draft Revised Guidance, EPA closely cooperated with and was subject to the supervision of the Department of Justice. ${ }^{432}$ Ultimately, supervision by the President and assistance by other agencies should alleviate competency concerns. Objections that such efforts will not be easy because they will require significant changes to how EPA conducts its business are merely excuses for avoiding the substantive calls for environmental justice rather than reasons why EPA cannot change.

A broader issue is raised by the relationship of environmental discrimination and inequity with larger patterns of discrimination and inequity within society. Many of the difficulties encountered by EPA in addressing the deeper structural and systemic aspects of discrimination and inequity in environmental justice are arguably symptomatic

431 See supra note 203.

432 See Draft Title VI Recipient and Revised Investigation Guidance, supra note 17, at 39,651; see also Exec. Order No. 12,250, 45 Fed. Reg. 72,995, 72,995-97 (Nov. 2, 1980). 
of the inadequacies of more generally prevailing legal understandings and approaches to race issues. ${ }^{433}$ Thus, one might argue that the problem is with the existing legal system as a whole rather than just the environmental regulatory system. ${ }^{434}$ Accordingly, the difficulties should be addressed by the government as a whole, through some inter-agency effort directed by the Executive Branch, rather than EPA specifically. ${ }^{435}$ EPA's efforts arguably should be secondary to interagency, government-wide efforts.

It would be an abdication, however, of EPA's larger societal responsibilities as well as its specific statutory obligations under Title VI, if it failed to pro-actively engage civil rights and equity issues within its regulatory jurisdiction. As an agency of the federal government, EPA has an independent responsibility, under the Constitution as well as the various federal civil rights statutes, including Title VI, to redress discrimination issues within its regulatory programs.

Civil rights statutes such as Title VI were, by design, addressed to all federal agencies rather than a few specific ones. ${ }^{436}$ Title VI recognizes the pervasive nature of racial discrimination and the special responsibility of the federal government to ensure that it does not become complicit in such discrimination through its funding assistance. ${ }^{437}$ By seeking to prevent racial discrimination in the activities of recipients of federal funds, Title VI, by necessity, cannot speak only to a few select federal agencies but must direct itself to all agencies dispensing federal funds. ${ }^{438}$ Even if EPA is less experienced in

${ }^{435}$ See generally supra Part II.C.1.

454 But see Yang, supra note 24.

495 In fact, the Executive Order on Environmental Justice established such an interagency working group to address environmental justice issues as a government-wide matter. Exec. Order No. 12,898, 59 Fed. Reg. 7629, 7629 (Feb. 11, 1994); see also An Integrated Federal Interagency Environmental Justice Action Agenda, at http://es.epa.gov/oeca/ $\mathrm{main} / \mathrm{ej} / \mathrm{iwg} /$ actionagenda.pdf (last visited Jan. 12, 2002).

436 See 42 U.S.C. $\S \S 2000 d-1$ (2000).

${ }^{437}$ President Kennedy, in his statement accompaying his proposal for the Civil Rights Act, stated to Congress that “[s]imple justice requires that public funds, to which all taxpayers of all races contribute, not be spent in any fashion which encourages, entrenches, subsidizes, or results in racial discrimination." See H.R. Doc. No. 124 (1963), reprinted in 1963 U.S.C.C.A.N. 1534.

${ }^{458}$ More importantly, the types of discrimination and equity issues implicated by EPA's regulatory activities are quite different from those dealt with by agencies such as the EEOC or HUD. Rather than attempting to balance the specific interests of individuals and the impacts on inter-personal relationships, the vast bulk of the discrimination and fairness issues raised by EPA's regulatory activities relates to the impact of governmental regulatory decisions and business activities on individuals or small communities. In that sense, EPA's task in addressing discrimination and equity issues is much like the traditional regulatory 
dealing with civil rights issues than agencies such as the EEOC, EPA's role is no less important within larger efforts to promote racial equality. And while EPA's statutory mission is focused on issues other than civil rights, the civil rights laws elevate its obligations to address civil rights concerns to a level no less important than its environmental priorities. ${ }^{439}$

By making each individual agency responsible for ensuring nondiscrimination in the federal funds that it administers, Title VI recognizes that discrimination comes in different forms and shapes. 440 Regulatory solutions that might apply to the discrimination issues faced by one agency might not be applicable to those faced by another.

Finally, and most importantly, as a federal agency, EPA does not act independent of the remaining federal government. It is, within the executive branch, subject to the control of the President and accountable in that fashion. ${ }^{441}$ With regard to the mandates of Title VI, Congress made such accountability explicit. 442 EPA's actions are ultimately attributable to the President as head of the executive branch. ${ }^{443}$ As an entity accountable to the President, whose responsibilities reach much further than the environmental mission of EPA to include the safe-guarding of civil rights, EPA's actions should be equally mindful of such broader responsibilities.

The crucial question in considering EPA's role in addressing civil rights and larger issues of fairness and equity is not whether EPA is competent to do so, or whether it should take the necessary yet difficult steps of achieving effective solutions to issues of environmental justice, but rather, what steps need to be taken to make its regulatory framework become more responsive to such issues.

actions it takes in other areas and is much less politically and socially sensitive than that of other agencies.

439 Title VI ensures that its anti-discrimination concerns are not elevated over EPA's environmental priorities. See 42 U.S.C. § 2000d-1.

440 See id.

441 Of course, such control may be limited by Congress. See, e.g., Morrison v. Olson, 487 U.S. 654, 664 (1988); Humphrey's Executor v. United States, 295 U.S. 602, 626 (1935). See generally MASHAW ET AL., supra note 200, at 169-280.

442 See 42 U.S.C. \$ 2000d-1; see also Charles F. Abernathy, Title VI and the Constitution: $A$ Regnilatory Model for Defining "Discrimination," 70 GEo. L.J. 1, 29, 31 (1981).

443 See Abernathy, supra note 442, at 31. 


\section{B. Taking Minority Protection Seriously in Administrative Proceedings: The Place of Administrative Adjudicative Processes}

As discussed above, one of EPA's principal difficulties has not been a failure to act on environmental justice issues, but rather a failure to confront the institutional and structural biases against the interests advanced by the environmental justice movement. ${ }^{444}$ The environmental laws' majoritarian orientation and their methodological bias toward quantifiable considerations have made incorporating civil rights concerns inherently difficult. ${ }^{445}$ An effective approach to environmental justice issues must include a process that resolutely protects the interests of those raising minority concerns and takes environmental justice concerns seriously.

This recognition re-emphasizes the inadequacy of EPA's Title VI Guidance. As noted previously, the entire process of investigating and deciding Title VI complaints is based on a process that is subject to political, and thus majoritarian, control. ${ }^{446}$ This orientation is exacerbated by the historically and institutionally close relationship that EPA has had with state and local governments-the primary targets of administrative Title VI complaints-and the attempts by the Guidance to extend some form of deference to state and local government. 447

The lack of real concern by the Guidance with minority protection issues and the interests of Title VI complainants is especially clear in EPA's statement regarding who ultimately controls the Title VI process: EPA and the federal fund recipient. ${ }^{448}$ Thus, "EPA does not represent the complainants, but rather the interests of the federal government, in ensuring nondiscrimination by its recipients." 449 The complainant may provide relevant information about the discrimination allegations, but he or she has no right of participation within the

444 See discussion supra Part I.B.

445 See discussion supra Part I.B.

446 See discussion supra Part I.G.

447 In such an environment, it seems inevitable that the "regulatory capture" of EPA by such interests will occur. See Stewart, supra note 208, at 1682-88, 1713-15. One would not expect the "capture" of the Title VI process to be obvious in the sense that most meritorious claims will be denied outright. Rather, it can be expected that review of Title VI claims will be perfunctory and technical in nature, and that claims that are not obviousty meritorious will not receive the serious consideration they deserve. Arguably, this already happened in the context of EPA's handling of the Select Steel matter. See Select Steel Complaint Letter, supra note 118.

448 Draft Títle VI Recipient and Revised Investigation Guidance, supra note 17, at 39,672 .

$449 \mathrm{Id}$ 
administrative process. ${ }^{450}$ And most importantly, the complainant has no right of appeal of an adverse determination on the complaint. ${ }^{451}$ In contrast, the federal fund recipient has the full panoply of participatory rights, including the right to administratively appeal any adverse decision. ${ }^{452}$

The Supreme Court's recent decision in Alexander v. Sandoval has done little to alleviate this disparity. ${ }^{453}$ While alternative avenues, such as suits under Section 1983, may keep open a significant avenue for private plaintiffs to pursue Title VI disparate impact claims in court, ${ }^{454}$ there remains a patent disparity in legal rights and remedies that individuals and communities complaining about the Title VI violations have in comparison to the targets of such complaints. ${ }^{455}$ After all, the administrative process was designed largely to allow complainants to avoid the expense, delay, and other burdens of litigation because of the enormous obstacles that such issues present to Title VI complainants seeking to vindicate their claims. ${ }^{456}$ Therefore, it proves that EPA's administration of laws protecting minority groups and the poor is subject to political control. 457

A change in this key failing of EPA's Title VI Guidance could significantly improve the consideration of minority interests in regulatory processes. ${ }^{458}$ As noted above, judicial decision-making is more solicitous of minority rights and incommensurable values than agency processes. Incorporating the attributes of the judicial process more closely into agency structures would improve minority protections within EPA's administrative decision-making.

The availability of administrative adjudicative processes under Title VI could significantly address these concerns. ${ }^{459}$ Of course, administrative law judges are not entirely independent of political control and do not have the broad public policy perspectives of Article III

450 Id.

451 Id.

452 Id.

453 See 121 S. Ct. 1511 (2001) (foreclosing a private right of action for individual plaintiffs to enforce Title VI disparate impact regulations directly in federal court).

454 See Mank, supra note 165.

${ }^{455}$ Id. But see South Camden Citizens in Action v. N.J. Dep't of Envtl. Prot., 274 F.3d 771 (3d Cir. 2001).

${ }_{456}$ Moreover, deferential review of agency actions by courts may largely insulate agency implementation of Title VI regulations from further challenge. See 42 U.S.C. \$ 2000d-2; see also Abernathy, supra note 442, at 39; Letter from Lawyers' Committee, supra note 248 , at 5.

${ }^{457}$ See Letter from Lawyers' Committee, supra note 248, at 5.

458 See generally id. at 5-7.

${ }^{459}$ See generally MASHAw ET AL., supra note 200, at 286-438. 
federal judges. ${ }^{460}$ Nevertheless, they are more insulated from political pressures than other agency employees ${ }^{461}$ and can thus be expected to implement some politically unpopular demands more readily than might be possible through other agency processes. ${ }^{462}$ Therefore, if minority protections suffer because of political pressure, administrative law judges can be expected to resist such pressures more easily than other agency employees.

Shifting decision-making control over environmental justice complaints to adjudicative processes without more reform, however, would only partially address problems of administrative decisionmaking. To improve the consideration of the incommensurables of environmental justice, administrative law judges would have to become more educated and cognizant of the history and concerns of civil rights law and the role of distributional equity and procedural fairness in public policy. ${ }^{463}$ The mixed outcomes of past EPA administrative decisions addressing environmental justice issues appear to confirm a lack of familiarity with and commitment to racial equality and social equity concerns. ${ }^{464}$ Without a greater appreciation of these issues, adjudicative processes are unlikely to significantly improve the consideration of environmental justice concerns. But more importantly, failure to change in this regard might simply return decisionmaking to the rote application of traditional civil rights jurisprudence without careful consideration of how the administrative agency mechanisms impact the application of this jurisprudence.

A recent decision by the Atomic Safety and Licensing Board of the Nuclear Regulatory Commission suggests that adjudicative processes can produce more searching inquiries with regard to the regulatory significance of racial and socio-economic disparate impacts. ${ }^{465}$ In

460 Federal judges are selected by political processes in the first place, and as a matter of practical reality, are not entirely free from political pressures. See, e.g., Chayes, supra note 172 , at $1307-08$.

461 See, e.g., 40 C.F.R. $\$ 22.8$ (2001) (limiting ex parte communications by administrative law judges and other agency officials connected to administrative proceedings during pendency of process). See generally id. $\$ 22$.

462 See Chayes, supra note 172, at 1307-08 (asserting that judges have a "professional ideal of reflective and dispassionate analysis of the problem before [them] and [are] likely to have had some experience in putting this ideal into practice").

46s See Richard Lazarus, Integrating Environmental Justice into EPA Permitting Authority, 26 Ecology L.Q. 617, 655-77 (1999).

${ }_{464}^{4}$ See id.

465 In re Louisiana Energy Serv., 47 N.R.C. 77, 100-07 (1998) (finding that NEPA, 42 U.S.C. $\$ \S 4321-4370$ e $(2000)$, required the Nuclear Regulatory Commission to consider environmental justice impacts in the Commission's licensing process, and remanding a 
that decision, the Board found that in light of the requirements of the Executive Order on Environmental Justice, the siting of a uranium enrichment facility in predominately poor and African-American communities raised potential racial discrimination issues. ${ }^{466}$ The decision itself has not been a panacea for environmental justice advocates because, on appeal to the politically appointed Commission members, the reach of the administrative decision was significantly curtailed. ${ }^{\mathbf{4} 7}$ And ultimately, every administrative adjudicative decision is subject to review by politically appointed and accountable agency heads. ${ }^{468}$

Nevertheless, administrative adjudicative processes arguably provide at least a starting point for taking a more serious look at changing the framework that so ill-serves environmental justice interests. ${ }^{469}$ They hold out the potential for far more principled and transparent decision-making with regard to minority concerns. ${ }^{470}$ And to the extent that environmental justice groups raise specific claims of discrimination and inequity, the characteristics of adjudicatory processes make them more suitable as mechanisms that will fairly address their concerns than other established agency processes. ${ }^{471}$

\section{The Scope of Regulatory Discretion Under Title VI and Environmental Statutes: Following the Path of NEPA}

Incorporation of adjudicative processes cannot be the sole answer to the improved consideration of environmental justice concerns because most agency decision-making processes cannot be adjudicatory. After all, the primary policy rationale for the creation of administrative agencies was to avoid the strictures of adjudicative processes that the common law posed for the technical and complex problems of environmental protection. Moreover, such process changes do not alter the substantive regulatory requirements that govern such decisions in the first place. To the extent that such regulatory requirements are hostile to or do not allow the consideration of discrimina-

nuclear material license for agency review to determine whether such concerns were adequately considered); see also Sheila Foster, Impact Assessment, in THE LAW OF ENvironmental Justice: Theories and Procedures to Address Disproportionate Risks, supra note 34 , at $272-82$.

466 See 47 N.R.C. at 104-06.

467 See Foster, supra note 465 , at 276-82.

468 Id.

469 Id.

$470 I d$.

$471 \mathrm{Id}$. 
tion or equity concerns, changing the process of decision-making will ultimately accomplish little. These limitations point out that another key step that EPA must take is to make more substantive changes within its regulatory processes.

Title VI potentially offers one important opportunity to achieve this goal. To realize the utility of Title VI, however, EPA will have to move beyond the use of its Title VI regulations purely as an enforcement tool of narrow conceptions of discrimination against federal fund recipients, as it has within its Title VI Guidance. Instead, EPA will need to utilize them more substantively as a source of authority for defining what types of actions lead to unacceptable discriminatory outcomes. ${ }^{472}$ At the same time, EPA must also heed more carefully the implicit call in Title VI to incorporate environmental justice considerations into all of its regulatory activities, a call that has been raised in the past with regard to the mandates of the Executive Order on Environmental Justice. 473 In essence, these tasks require EPA to address discrimination as a concern that shares much in common with issues of environmental degradation-a pervasive problem that is structural in nature..$^{474}$

The value of Title VI to these tasks is in its delegation of significant congressional authority to federal agencies to determine the prohibited forms of discrimination. ${ }^{475}$ In the past, this delegation

472 See generally 42 U.S.C. $\$ 2000 \mathrm{~d}-1$ (2000). Title VI was designed to prompt agency action because, as the Supreme Court recognized in the context of discrimination against the handicapped, much discrimination continues to be a present-day problem because of apathy, subconscious aversions, and the ease with which discrimination is perpetuated. See Alexander v. Choate, 469 U.S. 287, 295-96 (1985).

${ }^{473}$ Exec. Order No. 12,898, 59 Fed. Reg. 7629 (Feb. 16, 1994).

${ }^{474}$ For example, Heidi Gorovitz Robertson has pointed out that grandfathering of pollution permits has a significant impact on minority communities. Heidi Gorovitz Robertson, If Your Grandfather Could Pollute, So Can You: Environmental "Grandfather Clauses" and Their Role in Environmental Inequity, 45 CATH. U. L. REv. 131, 177-79 (1995).

475 Thus, the legislative history indicates that Congress intentionally left unclear what types of discrimination might be covered and subsequently prohibited within Title VI. See generally Abernathy, supra note 442, at 29-30. The rationale belind the discretion that was thus delegated to agencies was that different agency missions and regulatory structures called for different anti-discrimination protections. See id. (reviewing legislative history); see also Choate, 469 U.S. at 293-94.

The plain meaning of the text reveals Congress' intent to provide the relevant agencies with sufficient authority to transform the statute's broad aspiration into social reality. So too does a lengthy, consistent, and impassioned legislative history that strongly indicates that the Congress that adopted Title VI and the administration that proposed the statute both intended that agencies and departments would utilize the authority granted under $\S 602$ to shape the substantive contours of $\S 601$. For example, during the hearings that preceded the passage of the statute, Attorney General Robert Kennedy agreed that the 
of authority was used by agencies to promulgate regulations that prohibit discriminatory impacts as well as intentional discrimination. .76 $^{4}$ As Charles Abernathy argued two decades ago, however, this delegation of authority also calls on agencies such as EPA to adopt an understanding of Title VI based on a regulatory model of law making with broadly delegated powers and regulatory discretion to pursue antidiscrimination objectives. ${ }^{477}$ The Supreme Court has largely agreed with this understanding of Title VI. ${ }^{478}$

This model of federal law making is all too familiar to EPA. Federal environmental statutes delegate a significant amount of authority to EPA so that it may promulgate regulations that implement broad congressional mandates. ${ }^{479}$ Title VI is little different in this respect. ${ }^{480}$ EPA's regulatory experience with the pervasive nature of polluting activities and the incentives that affect activities leading to environmental degradation has given it a regulatory perspective and experi-

administrators of the various agencies would have the power to define "what constitutes discrimination" under Title VI and "what acts or omissions are to be forbidden." Civil Rights-The President's Program, 1963: Hearings Before the Senate Committee on the Judiciary, 88th Cong. 399-400 (1963); see also Civil Rights: Hearings Before the House Committee on the Judiciary, 88th Cong. 2740 (1963) (including remarks of Attorney General Kennedy) (stating only after the agencies "establish the rules" will recipients "understand what they can and cannot do"). It was, in fact, concern for this broad delegation that inspired Congress to amend the pending bill to ensure that all regulations issued pursuant to Title VI would have to be approved by the President. See 42 U.S.C. $\$ 2000$ d-1 (2000); Alexander v. Sandoval, 121 S. Ct. 1511, 1529-31, 1532 n.19 (2001) (Stevens, J., dissenting).

${ }^{476}$ See, e.g., Guardians Ass'n v. Civil Serv. Comm'n, 463 U.S. 582, 642 n.12 (1983) (Stevens, J., dissenting) ("Congress expected most interstitial lawmaking [for Title VI] to be performed by administrative agencies, not courts."); Madison-Hughes v. Shalala, 80 F.3d 1121 (6th Cir. 1996). At the same time, making such regulations subject to the approval of the President also addressed concerns about political accountability and narrow institutional competencies with regard to the ability to consider discrimination issues. See Abernathy, supra note 442 , at 31 . The President delegated this approval authority to the Attorney General. Exec. Order No. 12,250, Leadership and Coordination of Implementation and Enforcement of Nondiscrimination Laws, 42 Fed. Reg. 72,995 (Nov. 2, 1980).

477 See also Guardians Ass'n, 463 U.S. at 622-23 (Marshall, J., dissenting); Adams v. Bell, 711 F.2d 161, 181-83 (D.C. Cir. 1983) (Wright, J., dissenting); Abernathy, supra note 442.

478 Choate, 469 U.S. at 293-94 (stating that Title VI “delegated to the agencies . . the complex determination of what sorts of disparate impacts upon minorities constituted sufficiently significant social problems, and were readily enough remediable, to warrant altering the practices of federal grantees that had produced those impacts"); Guardians Ass' $n, 463$ U.S. at 592.

479 See Chevron U.S.A., Inc. v. Natural Res. Def. Council, Inc., 467 U.S. 837, 844-45 (1984).

${ }^{480}$ See Alexander v. Sandoval, 121 S. Ct. 1511,1532 (2001) (Stevens, J., dissenting). 
ence uniquely situated to address the pervasive nature and structural aspects of discrimination through Title VI. ${ }^{481}$

Arguably, since Title VI does not apply to EPA's activities itself, there could be inconsistent treatment-EPA might hold federal fund recipients to a higher or different standard than it holds its own regulatory activities. Yet, rather than holding itself to a lower standard, EPA should do more within its own activities to address the pervasive discrimination within American society. It must put into substantive practice what the Executive Order on Environmental Justice called on agencies to do in 1994-to incorporate environmental justice into all of their regulatory activities. ${ }^{482}$

In considering the expansive concern with unintentional discrimination by federal fund recipients and agency discretion under Title VI to address such discrimination, EPA has taken few substantive steps within its own programmatic activities. The recognition of the pervasiveness of discrimination and the authority delegated to EPA with respect to discrimination by federal fund recipients indicates that it must do much more to address the structural issues that cause and contribute to discrimination and inequity in environmental regulation. Further, EPA must take environmental justice concerns seriously as a substantive and programmatic matter, not just as a matter of public relations.

In many respects, these criticisms should be familiar to EPA. In 1969, Congress passed NEPA in order to force all federal agencies to consider the environmental consequences of their actions before making decisions. ${ }^{483}$ This principle has become most visibly embodied in NEPA's requirement that agencies prepare environmental impact statements that inform agency decisionmakers about the potential environmental consequences of particular agency decisions. ${ }^{484}$ While NEPA has had no substantive core, imposing only procedural requirements that must be satisfied before an administrative agency action can be finalized, it was also designed by Congress to change the very fabric of administrative decision-making. ${ }^{485}$ By forcing agencies to

481 In this respect, EPA's traditional focus on utilitarian outcomes, and less on process values, can actually help it address this underlying contribution to discrimination. See generally Tseming Yang, Balancing Interests and Maximizing Rights in Environmental Justice, $23 \mathrm{VT}$. L. REv. 529 (1999).

482 See Exec. Order No. 12,898, 59 Fed. Reg. 7629 (Feb. 16, 1994).

483 Pub. L. 91-190, 83 Stat. 852 (codified at 42 U.S.C. $\$ 4321$ (Jan. 1, 1970)).

484 See generally Zygmunt J.B. Plater et al., Environmental Law and Policy: NaTURE, LAW, AND SOCIETY 612-19 (2d ed. 1998).

${ }_{485}$ Id. 
interpret and administer all "policies, regulations, and public laws of the United States . . . in accordance with the policies set forth" under NEPA, ${ }^{486}$ it was designed to make them more aware of such consequences and ultimately to prompt agencies to alter their actions so as to minimize environmental harm. ${ }^{487}$

The parallels to the broad mandate of Title VI to ensure nondiscrimination by federal fund recipients should be apparent. In a sense, what Title VI calls on agencies to do-incorporate antidiscrimination protections into the programs receiving federal funding-is quite similar to NEPA's mandate to incorporate environmental considerations into agency decision-making. ${ }^{488}$ The implicit purpose of Title VI, however, is significantly more substantive in nature: full incorporation and implementation of Title VI's discrimination prohibitions in all of EPA's regulatory decision-making processes. ${ }^{489}$

From this perspective, the failure of EPA to heed Title VI's larger purpose of incorporating civil rights is particularly ironic. After all, EPA is the primary agency charged by Congress with monitoring agency compliance with NEPA. ${ }^{490}$ Of course, EPA itself has largely been exempted by the courts from the very application of NEPA because it is considered to perform functionally equivalent environmental analyses in those exempted programmatic activities. ${ }^{491}$ The exemption underscores not only that EPA has an appropriate role in

48642 U.S.C. $\$ 4332$ (2000).

${ }^{487}$ See Calvert's Cliffs' Coordinating Comm. v. United States Atomic Energy Agency, 449 F.2d 1109, $1112-13$ (D.C. Cir. 1971).

48842 U.S.C. $\$ 4332(\mathrm{~A})$.

489 Of course, Title VI appears to provide EPA with broad regulatory discretion in how to implement this goal. See Alexander v. Choate, 469 U.S. 293-94 (1985). But the exercise of such discretion, and what appropriate anti-discrimination requirements ought to be, would arguably be significantly affected by different premises about the role of antidiscrimination within environmental protection. Such premises are at issue here.

490 As the agency empowered to review and comment on the adequacy of environmental impact statements "from the standpoint of public health or welfare or environmental quality," EPA was essentially charged with ensuring that human health and environmental quality concerns became issues of primary concern not only to EPA and a few other agencies with environmental missions, but also to the federal government as a whole. Clean Air Act $\$ 309,42$ U.S.C. $\$ 7509$; see also 40 C.F.R. $\$ 1504.1$ (b) (2001). Within the NEPA scheme, EPA is specifically charged with reviewing and commenting on environmental impact statements. See 42 U.S.C. $\$ 4321$. Ultimately, the Council on Environmental Quality is the entity charged with judging the adequacy of agency implementation of NEPA. 42 U.S.C. $\$ 4344$; 40 C.F.R. $\$ \S 1500-1517$; see Andrus v. Sierra Club, 442 U.S. 347, 358 (1979).

491 See, e.g., Envtl. Def. Fund v. EPA, 489 F.2d 1247, 1256 (D.C. Cir. 1973); Wyoming v. Hathaway, 525 F.2d 66 (10th Cir. 1975). 
ensuring the compliance with broad statutes such as NEPA and Title VI by other governmental actors, but also that it has a legitimate role in doing so even if it itself is not subject to those regulatory requirements.

There is yet another implication that the functional equivalent exemption raises-the need for EPA to make much more serious efforts within its programmatic activities to achieve the substantive goals of Title VI, even if it is not subject to Title VI. EPA must make more purposeful efforts in exploring and applying the various legal authorities it already possesses under its federal environmental statutes to address discrimination and equity issues. As Richard Lazarus has pointed out, and as acknowledged by EPA itself, such authority does exist within EPA's various regulatory statutes. ${ }^{492}$ EPA must now actually use this statutory authority to improve the incorporation of environmental justice issues into its own regulatory activities.

One step that has been suggested is the incorporation of environmental justice considerations into the enforcement process, and in particular the assessment of penalties for regulatory violations. ${ }^{493}$ For instance, section 113(e)(1) of the Clean Air Act allows EPA to consider "such other factors as justice may require" in determining the penalty that is to be assessed. ${ }^{494}$ Increasing penalties based on discriminatory impacts could serve as a deterrent, and thus a disincentive, to greater pollution burdens imposed on environmental justice communities. Such increased penalties could outweigh the benefits a polluter might gain from the decreased likelihood of detection of violations and lower enforcement rates in environmental justice communities.

EPA's efforts, including its recently issued Title VI Guidance, may be the beginning of a long-term strategy to address and incorporate harms to environmental justice communities comprehensively into environmental regulation. And EPA's attempts to change its culture to listen more carefully to the complaints of environmental justice advocates are commendable.

492 See Lazarus, supra note 463; see also Envtl. LAW Inst., Opportunities for Advancing EnVironmental Justice: An Analysis of U.S. EPA Statutory Authorities (2001); EPA 'Buried' 1994 Plans for Major Environmental Justice Roadmap, INSIDE E.P.A. WEEKLY REP., Special Report, Mar, 3, 2000.

493 See Lazarus, supra note 463 , at $636-37,641$.

49442 U.S.C. $\$ 7413(\mathrm{e})(1)$; see also Clean Water Act $\$ 309(\mathrm{~g}), 33$ U.S.C. $\S 1319(\mathrm{~g})$ (2000); Safe Drinking Water Act $\S 3008,42$ U.S.C. $\S 6928(a)$ (3) (referencing the "seriousness of violation"). 
As noted above, however, EPA has yet to confront some key obstacles inherent in its institutional structure and methodological approaches. In particular, EPA's long delay in identifying appropriate statutory authority, without even beginning the process of acting on such authority, does not speak well to EPA's commitment to accomplishing the ultimate goal. ${ }^{495}$ Moreover, little has been done to begin incorporating such authorities into its regulatory decision-making processes. ${ }^{496}$ Such steps are crucial for any regulatory approach that takes the anti-discrimination and equity needs of the environmental justice movement as seriously as EPA's traditional environmental protection mission.

\section{CoNGLUSION}

EPA's attempts to address environmental justice issues by importing civil rights approaches into environmental regulatory schemes have largely been unsatisfactory and have given rise to serious criticisms. ${ }^{497}$ Much of this can be traced back to a failure to create appropriate regulatory approaches to environmental justice as well as the lack of a substantive understanding of environmental justice concerns. ${ }^{498}$ In creating a more effective process for dealing with environmental justice complaints, EPA will have to adjust both the form and substance of its regulatory mechanisms by considering more specifically minority protection concerns and incommensurable values . It must also adopt a more comprehensive regulatory approach that focuses on the structural incentives of discrimination.

In a way, the analysis reemphasizes the important lesson of the last several decades for environmental protection: a healthy and livable environment cannot be preserved or restored without proactive

${ }^{495}$ It took EPA almost six years to provide a partial analysis of existing legal authorities to address environmental justice issues within its regulatory activities.

496 For example, the incorporation of environmental justice considerations into its NEPA process is another important step forward in this regard. See National Environmental Justice Advisory Council Workgroup on Waste Transfer Stations, Notice of Public Hearing, 63 Fed. Reg. 58,045 (Oct. 29, 1998); see also Council on Environmental Quality, Environmental Justice Guidance Under the National Environmental Policy ACT (1997), at http://es.epa.gov/oeca/main/ej/docs/epafin.pdf (last visited Jan. 16, 2002); U.S. Envtz. Protection Agency, Final Guidance For Incorporating Environmental Justice Concerns in EPA's NEPA Compliance Analyses (1994), at http://es. epa.gov/oeca/ofa/ejepa.html (last visited Jan. 16, 2002). Yet, few of EPA's environmental regulatory processes are subject to NEPA. See discussion supra Part IV.C.

497 See discussion supra Part II.

498 See discussion supra Part III. 
efforts that challenge the status quo and seek changes to existing structures and institutions. The same is true for efforts aimed at achieving the ideals of equality and a just society. 